\title{
Liberties and Customs of the City of London - Are There any Left?
}

\author{
Graham S McBain ${ }^{1}$ \\ ${ }^{1}$ Solicitor. MA (Cantab), LLB (Cantab), LLM (Harv). Open Scholar, Peterhouse, Cambridge. Fulbright Scholar, \\ Harvard Law School. \\ Correspondence: Graham S McBain, 21 Millmead Terrace, Guildford, Surrey GU2 4AT, UK. E-mail: \\ gsmcbain@aol.com
}

Received: August 23, 2012 Accepted: December 17, 2012 Online Published: July 5, 2013

doi:10.5539/ilr.v2n1p32 URL: http://dx.doi.org/10.5539/ilr.v2n1p32

\begin{abstract}
The 'City of London' is famed throughout the world. However, few people realise that, today, it is actually very limited in physical ambit (to the 'Square Mile'). And, that it is not the same as the city of London as such. Nor, that it's mayor (the Lord Mayor of the City of London) is not the same as the Mayor of London (currently, Boris Johnson).

However, the City of London is governed by a series of charters from c. 1132. Charters in which sovereigns of England - in return for generous loans and sums of money - granted to the City of London many Crown prerogatives (privileges). These charters were to be replicated in numerous other charters granted to cities, boroughs and towns throughout England in the ensuing centuries.

This article argues that - in modern times - we need modern law. Law that is understandable to laymen as well as lawyers. It also argues that all these charters granted to the City of London are palpably obsolete and should be cancelled. If so, then so should those charters granted to cities, boroughs and towns. In this way, much obsolete law will be removed and the law made more intelligible. This can only be to the common good.
\end{abstract}

Keywords: crown prerogatives, franchise, city of London, charters, customs

\section{Introduction}

The City of London (the City) has had a long - but not necessarily amicable - historical association with the Crown. In times past, as well as being the capital of the country and the power base of English sovereigns, London was a fruitful source of funds for impecunious monarchs. ${ }^{1}$ In turn, its citizens often supported political factions which opposed the sovereign - especially when the occupant of the throne was rapacious. However, despite political differences, there remained a certain mutuality of relationship since, in exchange for frequent loans and gifts of money, the City would often receive specific Crown privileges not given to their fellow countrymen. These privileges were usually termed 'liberties' or 'franchises. ${ }^{2}$ The grant of liberties pre-dates the Norman conquest of 1066. The nature of some of these liberties are now lost in the mists of time; others are referred to in Crown charters and patents granted to the City. ${ }^{3}$ These liberties were jealously guarded by the citizens of London and, in return for money, sovereigns were usually happy to confirm them. Some sovereigns were also happy to seize the liberties of London back into their hands should the City incur their displeasure. Over time, many of the 'liberties'

\footnotetext{
${ }^{1}$ Bohun (1723), pp x-xv list the sums 'exacted, and I may say extorted from the city and citizens of London, under the pretence of granting their charters or confirming or restoring their rights and liberties.' The reference to the 'City' is used in this article to refer - in short form - to the 'mayor, commonalty and citizens of the City of London' (also often referred to, from the $19^{\text {th }}$ century onwards, as the Corporation of London). See also Halsbury Laws, 29 (2), para 40.

${ }^{2}$ Blackstone (1765-9), vol 2, p 37, 'Franchise and liberty are used as synonymous terms: and their definition is, a royal privilege, or branch of the king's prerogative, subsisting in the hands of a subject.' Chitty (1820), pp 118-9, 'The jura coronae or rights of the Crown, so long as they are attached to the king, are called prerogatives; but when such prerogatives are delegated to a subject, they acquire the appellation of franchise; for all franchises are derived from the king.'

${ }^{3}$ Texts on the City include: Allen (1858); Anon (1765); Arnold (1811); Birch (1884); Bohun, n 1); Calthrop (1670); COL (1953); Gomme (1907); Inwood (1998); Jacob (1732); LL (1680); Luffman (1793); Maitland (1756); Noorthouck (1773); Norton (1869); Page (1929); Pulling (1854); Riley (1859-62); Riley(1868); Riley (1863); Round (1899); Sharpe (1899, editor of the 'Letterbooks'); Stow (1965); Stubbs (1966); Thomas (1924-61). See generally, Sweet \& Maxwell (1955).
} 
granted to the City were extended to others - to the Cinque Ports, ${ }^{4}$ to boroughs ${ }^{5}$ and towns, as well as to individuals landowners.

In modern times, it is important for English law to be more accessible to the general public and to reflect prevailing social conditions. The purpose of this article is to analyse the liberties and customs of the City and to identify the extent to which they are now obsolete. Also, to consider whether the many charters granted to the City are still needed - or whether they have done their job and they can be cancelled. In respect of the liberties of the City, it should be noted that, today, they only extend to the 'Square Mile' ${ }^{6}$ - a small geographical part of the vast conurbation that presently comprises the capital. ${ }^{7}$ Thus, what was once granted to all the citizens of London now only applies to a tiny proportion of its inhabitants, an important factor to be bourn in mind.

When analysing the liberties granted to the City, reference may be made to legal texts on constitutional law ${ }^{8}$ as well as to those on legal history. ${ }^{9}$ Also, to the abridgments (major ${ }^{10}$ and minor $^{11}$ ) as well as to authors such as Coke $^{12}$ and Blackstone. ${ }^{13}$ Much useful material is contained in number of older texts on the laws, customs, rights and privileges of the City. ${ }^{14}$ The liberties granted to the City in charters from various sovereigns (see Appendix) as well as those arising from custom, fit into certain general categories. They may be summarised as follows:

- Taxes and Tolls. The City obtained exemption from various taxes (scot and lot, danegeld) as well as fines (murdrum, childwite, jeresgive, scotale, miskenning). It also gained the right to pay the same tallage and aids as other citizens as well as an exemption from tolls and a maximum sum for amercements;

- Judicial Rights. The City obtained the right to be tried by their own courts, that is, 'within the walls'. Also, freedom from 'wager by battle' as well as the rights of infangthef, outfangthef, escheat, waifs, estrays and treasure trove. Also, certain legal rights distinct from the common law in respect of: lands, promises, debts, wills as well as orphans, apprentices, feme sole, hostlers and defamatory words. The mayor and aldermen obtained the right to be justices of the peace (JP's) and the mayor, a justice of goal delivery and of oyer and terminer;

- War and Billeting. The City obtained exemption from being compelled to provide troops for war outside the City and to be free of billeting;

- Officials. The City obtained the right to appoint a mayor, sheriffs, chamberlain, common clerk and common sarjeant. Provision was also made for the annual election of aldermen;

- Offices of the Mayor. The mayor obtained the offices of : escheator, bailiff of the Thames, admiral of the port of London, clerk of the market, keeper of the great beam, gauger of merchandise, outroper, coroner, registrar of pawns, custodian of Bedlam, assistant to the butler at the coronation and lord lieutenant;

- Merchants and Markets. The City obtained the right to impose various restrictions on merchants as well as brokers. Also, the right to have: their own clerk of the market, courts of piepowder, market overt and freedom for purveyance. Further, the ability to impose: charges on the weighing, carriage, survey (ie. inspection) and the measurement of goods and coals;

\footnotetext{
${ }^{4}$ McBain (2011a).

${ }^{5}$ Ballard(1913), pp 180-94; Ballard \& Tait(1923); Weinbaum(1943); Madox (1989); Bateson (1904-5); Brady (1711) and Cam (1957).

${ }^{6}$ The Square Mile comprises an area of $1.12 \mathrm{sq} \mathrm{km} \mathrm{(including} \mathrm{Middle} \mathrm{and} \mathrm{Inner} \mathrm{Temple} \mathrm{and} \mathrm{the} \mathrm{river} \mathrm{Thames} \mathrm{adjoining,} \mathrm{to} \mathrm{the} \mathrm{middle} \mathrm{of} \mathrm{the}$ river, for certain purposes). This area can be altered under the Local Government Act 1992 and it is to be noted that the physical parameters of the City have undergone many charges over the centuries (including in 1994). The Square Mile is administered by the Corporation of London and has a resident population of c.10,000. It is divided into 25 wards for electoral puposes. See Halsbury, n 1, vol 29(2), para 31.

${ }^{7}$ Greater London comprises the city and 32 London boroughs. It has an area of 607 sq miles and a population of c. 7.7m (2009). It is administered by the Greater London Authority and has a directly elected mayor (not to be confused with the lord mayor of the City of London). See Halsbury, n 1, vol 29(2), para 34.

${ }^{8}$ Anson (1935); Barendt (1998); Bradley \& Ewing (2006); De Smith \& Brazier (1998); Dicey (1948); Phillips \& Jackson (2001); Le Sueur \& Sunkin (1997); Jennings (1959); Marshall (1971); Sunkin \& Payne (1999).

${ }^{9}$ Brougham (1861); Hallam (1897); Jolliffe (1948); Keir \& Lawson (1979), ch 2 (intro); Maitland (1963); Petit-Dutaillis \& Lefebre (1930); Robertson, (1935); Stubbs (1883); Taswell-Langmead (1960); Thomson (1938); Wilkinson (1958). See also Allen (1849).

${ }^{10}$ Brooke (1586); Fitzherbert (1577); Rolle (1668); Statham (c. 1490).

${ }^{11}$ Bacon (1798); Comyns (1822); D’Anvers (1725-37); Hughes (1660-3); Lilley (1765); Nelson (1725-6); Sheppard (1759); Viner (1741-57).

${ }^{12}$ Coke (1824).

${ }^{13}$ See $n 2$.

${ }^{14}$ See $\mathrm{n} 3$. A bibliography of the various Royal Commissions on London may be found in Owen (1982). Of particular note are: (a) RC, vol 18, app 3 (it contains a useful statement on the origin, position, powers, duties and finance of the Corporation of London); (b) RC-54 and; (c) CMC (it contains useful material on the charters, see pp 5-27).
} 
- Miscellaneous. The City obtained the right to bear maces of gold and silver. Also, confirmation of their hunting rights.

The purpose of the article is to consider when the above liberties and customs became obsolete, as well as any others granted to the City.

\section{Liberties of London and Magna Carta}

The liberties and customs of the City are reflected in Magna Carta 1297, chapter (section) 9 which is still extant. ${ }^{15}$ It provides:

The city of London shall have all the old liberties and customs [which it hath been used to have].

Moreover we will and grant that all other cities, boroughs, towns, and the barons of the five ports, ${ }^{16}$ and all other ports, shall have all their liberties and free customs. ${ }^{17}$

The distinction between 'liberties' (franchises) and 'customs' is that the former derives from a Crown grant (whether by charter or patent) whereas the latter is contrary to the common law ${ }^{18}$ and it detracts from the general law. Chapter 9 of Magna Carta 1297 was reflected in the original Magna Carta of 1215, ch 13. ${ }^{19}$ Thus the reference to 'old liberties and customs' was to those prevailing pre-1215.

- What they were is reflected, to some extent, in the charters granted to the City by previous sovereigns beginning with the charter of William I (1066-87) up until 1215 (see Appendix, nos 1-11). These charters make reference to various matters of Anglo-Saxon law such as: the court of Hustings, folkmotes, wardmotes, sokes, withernam, exemption from pleas outside the walls, wager of battle, miskennings, scot and lot, bridtoll (bridgetoll) and danegeld; ${ }^{20}$

- Whether these liberties had also been granted to the citizens of London pre-1066, and exactly what other liberties had been granted prior to that date, is unclear. As it is, the laws of the Anglo-Saxon kings ${ }^{21}$ refer to few liberties being given to London in particular. ${ }^{22}$ This is not unexpected, since the City, pre-1066, had not achieved the significance of being the capital of a unified country that it later achieved. Also, any such other liberties or other customs (which, in any case, would have comprised legal rights similar to those summarised in the Introduction) ${ }^{23}$ will have long been superceded.

In conclusion, Magna Carta confirms that the City shall have all the 'liberties and customs' that it had pre-1297. The question is whether any still exist and - if they do - if they are obsolete or not.

\footnotetext{
${ }^{15}$ For general texts see McKechnie (1914) and Holt (1969).

${ }^{16}$ The Cinque Ports comprised: Dover, Sandwich, Romney, Hastings and Hythe. To these Winchelsea and Rye were added soon after the Norman Conquest (the two 'Ancient Towns'). Strictly, the reference today should be to 'The five Cinque Ports and the Town Ancient Towns' although all seven are invariably referred to as the 'Confederation of the Cinque Ports', despite the misnomer.

${ }^{17}$ Halsbury, Statutes, vol 10. See also Coke, n 12, vol 4, p 20 and CMC, n 14, p 6.

${ }^{18}$ Halsbury, n 1, vol 12(1) para 603 'Liberties and franchises may also be claimed by immemorial usage, and in old charters are sometimes mentioned together with customs [citing Magna Carta, ch 9, see text]. However, a custom is distinguished from a franchise in that a franchise lies in grant, whereas a custom runs contrary to the common law and therefore cannot be derived from a Crown grant'. See also John Spelman's Reading on Quo Warranto, Selden Society, vol 113, p 7 which contains Hervey's Reading on ch 9 (c.1480's) 'Customs are properly usages against common right, which by common presumption cannot begin by patent of the king's forebears...' See also an Anonymous Reading (c. 1500) at $\mathrm{p} 10$.

${ }^{19}$ McKechnie, n 15, p 241 'And the city of London shall have all its ancient liberties and free customs, as well by land as by water.' ('Et civitas Londonie habeat omnes antiquas libertates et liberas consuetudines suas, tam per terram quam per aquas.')

${ }^{20}$ Bohun, $\mathrm{n} 1, \mathrm{p}$ viii 'tis evident, the said city and citizens had and enjoyed most of the liberties and privileges mentioned in the following charters (besides divers others not therein enumerated) by immenorial usage and custom long before the arrival of William I [1066-87].' Also, p x. See also Stenton (1989), p 58 'some of the privileges which the men of London claimed in the twelfth century may have been inherited from the traders whose settlement had founded the Saxon city.'

${ }^{21}$ For texts on Anglo-Sxon law see Attenborough (1922); Robertson (1925); Thorpe (1840); Liebermann (1916). See also Whitelock (1965); O'Brien (1999) and Thomas (1924), p ix.

${ }^{22}$ Anglo-Saxon laws that were London specific comprised: (a) Laws of Ethelstan VI (c.940), see Attenborough, n 21, pp 157-69 and; (b) Laws of Ethelred IV (c 991-1002), see Robertson, n 21, pp 71-9. See also Liebermann, n 21, vol 1, pp 673-5 (a custumal, the Libertas Londoniensis, compiled in the first half of the 12th c, now online see www.earlyenglishlaws.ac.uk, University of London, Institute of Historical Research) and M Bateson, A London Municipal Collection of the Reign of John (1902) vol 17, pp 707-30.

${ }^{23}$ Anglo-Saxon laws were few. Further, such liberties granted were almost invariably linked to taxation (and tolls), judicial jurisdiction and amercements (fines). See 19.1.
} 


\section{Liberty - To Be Law Worthy}

When considering the liberties of the City the primary source are the charters granted to the City over the centuries. The $1^{\text {st }}$ charter of William I (1066-87) to the City - which was in Anglo-Saxon language and which may have been issued in 1067 - provides:

I declare, that I grant you to be all law-worthy, as you were in the days of king Edward [the Confessor $(1042-66)] ;{ }^{24}$ and I grant that every child shall be his father's heir, after his father's days [ie. death]; and I will not suffer any person to do you wrong. ${ }^{25}$

The liberties granted to the citizens of London were the recognition that the citizens were 'law worthy' (legalitas) ${ }^{26}$ and that they had the right to devise their property. In respect of the former, Birch notes there are two possible interpretations of this term:

- Freemen were entitled to the benefit of the law - but not those in servile status to their lords and who received justice from them (ie. serfs or villeins). ${ }^{27}$ Thus, William I recognised the status of the citizens of London as being freemen; and

- Men were law-worthy when they had committed no crime (legales homines). ${ }^{28}$

It is asserted that the charter of William I (1066-87) to the citizens of London may have been intended to cover both interpretations:

- The first, since the other liberty granted is that their children should be their heirs, something which did not happen in the case of those who held their land at the will of their lord. They had no right to devise their property. ${ }^{29}$ 'Law worthy', therefore, distinguished a 'freeman' from a 'villein'. More especially, the charter confirmed that Londoners would continue to have the same rights as they did under Edward the Confessor (1042-66). ${ }^{30}$ Exactly what the laws of Edward the Confessor were is a matter of some conjecture although 39 articles have been (probably wrongfully) ascribed to him. ${ }^{31}$ These laws are no longer of legal effect, nor do they make specific provision for London in any case. However, it has been claimed that the laws of the Confessor provided that - if a person of servile condition (a villein) lived in the City for a year and a day peacefully - they became a free citizen of London. Thus, they were freed

\footnotetext{
${ }^{24}$ Bohun, $\mathrm{n} \mathrm{1,} \mathrm{p} \mathrm{x} \mathrm{'be} \mathrm{lawworthy} \mathrm{as} \mathrm{they} \mathrm{were} \mathrm{in} \mathrm{king} \mathrm{Edward's} \mathrm{days,} \mathrm{do} \mathrm{plainly} \mathrm{imply} \mathrm{the} \mathrm{said} \mathrm{citizens} \mathrm{were} \mathrm{possessed} \mathrm{of} \mathrm{divers} \mathrm{rights;}$ privileges and customs in the confessor's days; so tis apparent, not only London, but the whole nation, was then possessed of the like rights, customs and privileges, as the free election of their sheriffs, aldermen, domesmen, justices, coroners, and particularly of all their heretochs or commanders of military forces, etc.' For the alleged laws of William I including one that every man is to enjoy the laws of Edward the Confessor, see Stubbs (1966), p 99.

${ }^{25}$ Birch, n 3, pp xi \& 1. Cf. Robertson, n 21, p 231. The charter commences with a greeting. 'William the king friendly salutes the bishop, and Godfrey the portreve, and all the burgesses [citizens] within London, both French and English.' For the reference to 'burgesses' (burghers), see Norton, n 3, pp 260-1. RC, n 14, vol 18, p 24 'The charter granted by William I is not a grant to the City of corporate privileges. It only confirms those already in existence. The terms of the charter clearly point to the king's intention not to reduce the citizens to a state of vassalage, but to establish them in all the rights and privileges they had enjoyed since the days of Edward the Confessor.'

For a latin translation of the charter see Riley, n 3, (Munimenta, Liber Custumarum, part 1, p 247 (In particular, 'Et ego vobis notum facio, quod ego volo quod vos sitis omni lege illa digni qua fuistis Edwardi diebus regis'). For a photo, see www.cityof London.gov.uk

${ }^{26}$ Oxford English Dictionary (OED)(law worthy) 'worthy of (ie. entitled to) the laws. a. Of Persons: having a standing in the law courts, possessed of full legal rights.'

${ }^{27}$ Birch, n 3, p x 'By the state and condition of men's persons; so almost all free men had the free benefit of the law. But men of servile condition had not, especially such as were in dominio, in demesne, for they received justice from their lords, were judged by them in most cases, and had not the true benefit of the law; so neither, as to the second observation in this charter, could their children be their heirs, for they held their lands and goods at the will of the lord, and were not sure to enjoy them longer than they pleased him.' Walker (1980)(villein) 'In medieval English law, a composite class of persons, comprising slaves as known in Anglo-Saxon law and free, yet dependent, cultivators of the soil whose tenure was defined by Norman lawyers as unfree because they owed duties to their lords indefinite in nature and extent...[Villeinage] survived, however, to the late sixteenth century before falling in to complete disuse.' On villeinage generally, see Blackstone, n 2, vol 2, p 93 et seq. and Vinogradoff (1892).

${ }^{28}$ Birch, n 3, pp x-xi. Also, Brady, n 5, pp 16-7 and Norton, n 3, p 265 (liber et legalis homo).

${ }^{29}$ See Norton, n 3, p 29 'This class of persons were in a state of absolute dependency on their lord's will.' Cf. freeman. ibid, pp 33, 266.

${ }^{30}$ Robertson, n 21, p 223 'It is an explicit statement of his intention to continue the privileges enjoyed under his predecessor, to pay due regard to the laws of inheritance, and to protect the citizens from injury.' Norton, n 3, p 258 'It merely declares that the Conqueror will not reduce the citizens to a state of dependent and slavish vassalage.' See also Sharpe (1894), p 36 and Birch, n 3, pp xi \& 1. See also Hume (1884), vol 1, App 2, $\mathrm{p} 451$ (that the citizens of London would not be treated as slaves).

${ }^{31}$ See O'Brien, n 21, p 158 et seq.
} 
from their servile status. ${ }^{32}$ In conclusion, the charter of William I recognised that all the citizens of London were freemen; ${ }^{33}$

- The second, since it connoted that the citizens of London possessed their legal rights intact, especially in the courts of justice. ${ }^{34}$ This was important since the citizens of London would not know their status with regard to the new conqueror; it was uncertain whether William I intended to treat them as enemies or as having committed a crime against him, their not having supported his claim to the throne as against king Harold (1066). ${ }^{35}$

Today, regardless of whether this charter should be interpreted in one - or both - of the above senses, it is obsolete. Villeinage became obsolete in the $16^{\text {th }}$ century ${ }^{36}$ and, today, all citizens are freemen (or women) possessing legal rights - including the right to devise their property to their heirs. ${ }^{37} \mathrm{~A}$ second charter of William I which is often linked with the charters of London, is also obsolete. In Anglo-Saxon, it confirms to one Deorman, land of which he had been deprived. ${ }^{38}$

\section{In conclusion, the two charters of William I to the City are obsolete.}

\section{Liberty - To Appoint Sheriffs}

\subsection{Terms of the Charters}

Stubbs noted the lack of municipal organisation in the London of the $11^{\text {th }}$ century, describing the capital as a 'bundle of communities, townships, parishes, and lordships, of which each has its own constitution. ${ }^{39}$ That said, certain Anglo-Saxon institutions persisted into the reign of Henry I (1100-35). Thus, London had, inter alia, a:

- Folkmoot ${ }^{40}$ - a reference to an assembly of all the citizens. Also, to the sheriff's court;

- Hustings - a reference to a council of elders. Also, to the court of hustings; ${ }^{41}$

- Portreeve - a chief officer. Later, replaced by a lord mayor. ${ }^{42}$

Whether William I (1066-87) issued other charters to the City is unknown. ${ }^{43}$ The next charter generally cited in legal texts is one of Henry I (1100-35) issued c. 1132 (see Appendix). It granted certain liberties to the citizens of

\footnotetext{
${ }^{32}$ Bohun, $\mathrm{n} 1, \mathrm{p}$ ix, 'This is indeed said to have been granted to the said city by a charter of Edward the Confessor; but 'tis evident the same custom or privilege was in being in the time of the Britons, particularly in the reign of Dunwallo Molmutius, who began circa AD 480.' Regardless of this right in the time of Edward the Confessor, in the Norman period if a villein resided for a year and a day within the walls of a free borough, unreclaimed, he thereby effected his enfranchisement. See Pulling, n 3, p 380; Stubbs, n 9, p 466; Bateson, n 5, vol 2, p 89 (quoting a London MS of 1135) and Calthrop, n 3, p 116.

${ }^{33}$ Norton, n 3, pp 92, 99.

${ }^{34}$ Ibid, p 264 'the citizens were to enjoy the privileges of freemen in courts of justice; for by the Saxon as well as the feudal system of law, none but freemen were entitled to the privileges of trial according to any recognised judicial form, either in civil or criminal courts.'

${ }^{35}$ William I maintained that king Harold (1066) had usurped his rights to the throne. For examples of people being (or not) law worthy, see O'Brien, n 21, p 81 (a thief lost his 'law worthiness'. So too did traitors and outlaws), p 170 (under the Laws of Edward the Confessor, the wife of a guilty man could clear herself by ordeal and remain 'law worthy' (legales) with her marriage portion and dower unaffected), p 87 'At a basic level, being law worthy meant having the trust of one's neighbours. This trust enabled the person to participate in the administration of justice in various ways...'

${ }^{36}$ See $\mathrm{n} 27$.

${ }^{37}$ The wording in the charter of William I on heirship may also have sought to exempt the citizens of London from the rule of primogeniture which prevailed among the Normans. However, this exemption did not last for long, as observed by Allen, n 3, p 4.

${ }^{38}$ Birch, n 3, p 2 'I have granted to Deorman, my man (homo), the hide of land at Gyddesdune, of which he was deprived, and I will not suffer either the French or the English to hurt him in anything.' As Birch, n 3, points out, p xiii, this is not a city charter as such; rather it is a prívate title deed to land 'which must have passed (the charter itself going with the land) into the possession of the city authorities.' Gyddesdune was probably Gaddesden (Gadsden) in Hertfordshire, when it was part of East Saxony. See also Norton, n 3, p 257 and Luffman, n 3, p 4.

${ }^{39}$ Stubbs, n 9, pp 439, 442. See also McKechnie, n 15, p 241.

${ }^{40}$ OED, n 26, 'A general assembly of the people of a town, city or shire.' Stubbs, n 9, p 133, 'The folkmoot, or popular assembly of the shire.' Walker, n 27 (folkmoot) 'An assembly of the people in medieval times to deal with matters of common concern. Such gatherings included the shire moots, or shire court, the hundred court, and the sheriff's tourn.'

${ }^{41}$ Pulling, n 3, p 170 'The word hustings signifies, in the Saxon language, the house of causes or things, or a general council or court.' OED, $n$ 26 (hustings) '1. An assembly for deliberative purposes, esp. one summoned by a King or other leader: a council. 2. A court held in the Guildhall of London by the lord mayor, recorder, and sheriffs (or aldermen), long the supreme court of the city.'

${ }^{42}$ OED, n 26, (portreeve, portgrave). 'The ruler or chief officer of a town or borough; after the Norman Conquest often identified with the mayor or holding an equivalent position.' O'Brien, n 21, p 100 'the portgerefa, the reeve serving a larger city or market town.' See also Stow, n 3, p 490 .
} 
London. These included the liberty to appoint two sheriffs for the City and Middlesex - both of which lands were leased from the sovereign. Also, the liberty to appoint a justiciar, to handle pleas of the Crown. As to these, the concept of sheriff (shire reeve) derives from Anglo-Saxon times. The sheriff was an executive officer of the Crown responsible for collecting taxes and enforcing the law. ${ }^{44}$ However, prior to the Norman Conquest, the sheriff had ceased to collect rents on behalf of the sovereign. Instead, he became a rent collector or farmer (firmarius), buying the right to such revenues in return for a fixed annual rent or farm (firma comitatus) ${ }^{45}$ which he paid to the exchequer, for the sovereign. ${ }^{46}$ In the case of London, initially, the sheriff was appointed by the sovereign and was a royal official. ${ }^{47}$ However, the charter of Henry I of c. $1132^{48}$ provides (the original was in latin) for the citizens of London to be able to elect their own sheriffs. It states:

I have granted to my citizens of London, to hold Middlesex to farm for [£300], upon accompt to them and their heirs; so that the said citizens shall place as sheriff [vicecomitem] whom they will of themselves;

and shall place whomsoever [justitiarium, a justiciar], or such a one as they will of themselves, for keeping of the pleas of the crown, and of the pleadings of the same, and none other shall be justice over the same men of London... ${ }^{49}$

Thus, for an annual farm (quit rent) of $£ 300$, the citizens of London acquired:

- a lease over the City and the county of Middlesex;

- the right to choose sheriffs both for the City and for Middlesex ${ }^{50}$ - albeit the wording in the charter is unclear since it appears to only refer to the latter, ${ }^{51}$

- the right to choose a justiciar to hold pleas of the crown. As it was, the office of justiciar did not last long, becoming extinct after $1265 .{ }^{52}$

\footnotetext{
${ }^{43}$ Sharpe, n 30, vol 1, pp 36-7 'It is recorded that William granted another charter to the citizens of London, vesting in them the city and sheriffwick of London, and this charter the citizens proferred as evidence of their rights over the cloister and church of St Martin Le Grand, when those rights were challenged in the reign of Henry VI [1422-71]. This charter has since been lost.' One is dubious about the existence of such a charter since, if it existed, it would very likely have been referred to in the many charters granted to the City after William I.

${ }^{44}$ Walker, n 27 (sheriff) 'Originally shire reeve, a person who performs various administrative functions, in a county or district. The office existed before the Norman Conquest, being probably created as part of the reorganisation of local government consequent on the reconquest of the Danelaw. He was a royal official and took over the functions, particularly collection of monies due to the king, formerly performed in the burghal areas by the King's reeve.' Stubbs, n 9, pp 126-7, 'The sheriff...was the king's steward and judicial president of the shire, the administrator of the royal demesne and executor of the law...As a rule he was, as a royal officer, nominated by the King...The sheriff...was entitled to a share of the profits of administration, and possibly had in some cases an endowment in law.' See generally, Blackstone, $\mathrm{n} 2$, vol 1, p 328 et seq. See also Bohun, n 1, pp 39-40 and Anon, n 3, pp 40-1.

${ }^{45}$ For the Anglo-Saxon derivation of the word 'farm' (feorme) see Blackstone, n 2, vol 2, p 318. Also, McKechnie, n 15, p 318. See also Madge (1938), p 33 'This fixed annual payment was called the 'firma comitatus' or 'corpus comitatus', the farm or body of the shire.'

${ }^{46}$ Payments were made at Easter and Michaelmas, see Stubbs, n 9, p 409.

${ }^{47}$ The 1st charter of William I, see 2, refers to Gosfrith (probably Geoffrey de Mandeville), the port reeve who was also sheriff of Middlesex, see COL, n 3, p 3. It seems likely there were two sheriffs at the time of the Conquest, see Inwood, n 3, pp 55-6. The sheriff was also often referred to by the Anglo-Norman term, bailiff.

${ }^{48}$ When this charter was issued is unclear, although a date of 1132 is likely. Also, whether it is genuine. No original of the charter exists, albeit there are a number of copies, many of which are likely corrupt. See Brooke (1973), vol 4, pp 575-6 (not genuine); Hollister (1980), Journal of Medieval History (1980), vol 6, pp 289-306 (genuine), Keene (2008), 6th series, vol 18, pp 69-99 (not genuine). See also Inwood, n 3, p 57.

${ }^{49}$ Robertson, n 21, p 289 gives a clearer translation 'I have granted Middlesex to my citizens of London to be held on lease by them and their heirs of me and my heirs for $£ 300$ paid by tale, upon such terms: that the citizens themselves appoint a sheriff, such as they desire, from among themselves, and a justiciar, such as they desire, from among themselves, to safeguard the pleas of my Crown and to conduct such pleas. And there shall be no other justiciar over the men of London.' See also COL, n 3, p 5. For the difference between the sheriff and the justiciar, see Round (1892), p 106 et seq.

${ }^{50}$ McKechnie, n 15, pp 241, 317-21. See also Norton, n 3, pp 55, 60.

${ }^{51}$ Noted by Pulling, n 3, p 133. Ibid, p 132 'two sheriffs were appointed instead of one, that there might be greater security for the due performance of the office.' That said, often, the sheriff of London and of Middlesex was one and the same. See Round, n 49, p 347 et seq. Also, Stubbs, n 9, p 673. The connection between London and Middlesex was longstanding, see Stenton, n 20, p 54.

${ }_{52}$ Baker (2002), p 15 (not regularly appointed after 1234 and last was Hugh le Despenser who died 1265). See also COL, n 3, p 69 and RC, n 14, vol 18, p 24. A charter of Henry II of c. 1155 (see Birch, n 3, pp 5-6 and Appendix), did not refer to sheriffs or to a justiciar. Further, the reference to a 'justiciar' dropped out of the picture by the time of the charter of John of 1199 (see above text). McKechnie, n 15, p 245 'the liberty to appoint a justiciar of their own, now seemed to be inconsistent with the Crown's centralizing policy, was abandoned.' See also Robertson, n 21, p 373; Stubbs, n 9, p 374 and Norton, n 3, pp 270-7. Sharpe, n 30, vol 1, p 43 thought the justiciar's role, in any case, may have
} 
It has been asserted by Round that this charter of Henry I was cancelled by king Stephen (1135-54) who appointed the Earl of Essex (Geoffrey de Mandeville) as sheriff and justiciar for London and Middlesex in $1141 .{ }^{53}$ Such a thesis is not material to the present article, since it is not disputed that the liberty to the citizens of London to choose their sheriffs was repeated in a subsequent charter, that of king John (1199-1216) of 5 July 1199. It provides:

we have granted, and by this our present writing confirmed, to our citizens of London, the sheriffwicks of London and Middlesex, with all the customs and things to the sheriffwick belonging, within the city and without, by land and by water, to have and to hold, to them and their heirs, of us and our heirs, paying therefore $[£ 300] \ldots$ And further, we have granted to the citizens of London, that they amongst themselves make sheriffs whom they will; and may amove them when they will; and those whom they make sheriffs, they shall present to the justices of our exchequer, of these things which to the said sheriffwick appertain, whereof they ought to answer to us... ${ }^{54}$

The sheriffs were responsible for paying the annual rent of $£ 300$. If they failed it to do so, the charter imposed the obligation on the citizens. ${ }^{55}$ This right of the citizens of London to select their sheriffs is again repeated in a charter of Henry III of 18 February 1227. ${ }^{56}$ Further, the Constitutions for the regular Government of the City granted by Edward II on 8 June 1319 provide that:

sheriffs of the same city be elected by the citizens of the said city, according to the tenor of the charters of our progenitors, heretofore kings of England, made to them thereby, and no[t] otherwise..... ${ }^{57}$

The Constitutions also permits the sheriffs to appoint deputies - something not untoward given the many tax collecting and judicial functions which they exercised at that time. ${ }^{58}$ Finally, a $1^{\text {st }}$ charter of Edward III of 6 March 1327 confirms the right of the citizens of London to hold the sheriffwicks for $£ 300 .^{59}$ It also makes provision for:

- the amercement of the sheriffs (ie. their being fined) for failing to carry out their office properly, such as in permitting the escape of thieves; ${ }^{60}$

been handled by the sheriff transacting business under the king's writ. See also p 58. Petit-Dutailis, $\mathrm{n} 9, \mathrm{p} 95$ 'The office of justiciar, doubtless incompatible with the circuits of the itinerant justices, disappears.' See also Ballard, $\mathrm{n} 5$, p lxxxvii.

${ }^{53}$ Round, n 49, pp 142, 150, 367. For an appraisal of Round's theory, see Geoffrey de Mandeville, see DNB. See also McKechnie, n 15, pp $242-3$.

${ }^{54}$ The charter continues 'we will and steadfastly command, that the citizens of London and their heirs may have and hold the sheriffwick of London and Middlesex, with all things to the said sheriffwick belonging, of us and our heirs, to possess and enjoy hereditarily, freely and quietly, honourably and wholly, by the fee farm of [£300]; and we forbid none to presume to do any damage, impediment or dimishment to the citizens of London of these things, which to the said sheriffwick do or were accustomed to appertain: And we will and command, that if we or our heirs, or any of our justices, shall give or grant to any person any of those things which to the farm of the sheriffwick appertain, the same shall be accounted to the citizens of London, in the acquittal of the said farm at our exchequer.' See Birch, n 3, pp 15-7 and Pulling, n 3, p 133. See also Ballard, n 5, p lxxxv.

${ }^{55}$ 'unless they [the sheriffs] shall sufficiently answer and satisfy, the citizens may answer and satisfy us the amerciaments and farm.' Birch, $\mathrm{n} 3$, p 16. See also Norton, n 3, pp 312-3 and Madox, n 5, pp 164-75.

56 'we have granted, and by these presents do grant and confirm, unto the citizens of London, the sheriffwick of London and Middlesex, with all the customs and things to the same sheriffiwick belonging, within the city and without, by land and by water, to have and to hold, to them and to their heirs, paying... [£300 pa]...And further, we have granted to the citizens of London, that they may among themselves may make sheriffs whom they will, and may amove them when they will; and those whom they may make sheriffs, they shall present to our justices, who may answer to us and our justices in the exchequer of those things which to the sherrifwick appertain, whereof they ought to answer to us. See Birch, n 3, pp 21-3.

${ }^{57}$ Birch, n 3, pp 45-6.

58 'That sheriffs have but two clerks and two sarjeants; and that they take such for whom they will answer... That the sheriffs for the time being commit toll, and other customs belonging to their farm, and other public offices belonging to them, and to be exercised by others, to sufficient men, for whom they will answer, and not commit them to others. And if any deputed by the said sheriffs to any of the aforesaid offices, take undue custom, or carry himself otherwise in that office than he ought and is thereupon convicted at the suit of the complainant, let him be removed from that office, and punished according to his demerits.' See Birch, n 3, pp 45,48 and RC, n 14, vol 18, p 73.

59 The sum had been raised to $£ 400$ in the period 1270-1326 and so this charter provided 'we will..that the said citizens, may henceforth hold the aforesaid sheriffwicks for [£300]... according to the tenor of the aforesaid charters.' See Birch, n 3, p 53; Round, n 49, p 359; Sharpe, n 30, p 104. This charter of 1327 was held to have the force of an Act of Parliament, see Islington Market Bill (1825) 3 Cl \& Fin 513 (6 ER 1530). See also Sharpe, n 30, vol 1, p 160.

${ }^{60}$ This applied when the sheriffs exercised a judicial function. The limit of fine which could be imposed on them was $£ 20$, see $3^{\text {rd }}$ charter of John of 5 July 1199 and Birch, n 3, pp 15-6. See also: (a) $1^{\text {st }}$ charter of Henry III of 18 February 1227 (it confirmed a maximum sum of £20). 
- the sheriffs not being compelled to take an oath at the exchequer, save when handing in the farm of $£ 300 ;{ }^{61}$ and

- the sheriffs to have forfeiture of victuals (ie. receipt of the fines imposed for selling unsound goods). ${ }^{62}$ These appear to be the only references to the sheriffs in charters granted to the City. ${ }^{63}$ Subsequent to these charters, in 1748, an Act was passed to repeal all former acts, orders and ordinances on the election of sheriffs. ${ }^{64}$

\subsection{Declining Role of the Sheriffs}

By the $19^{\text {th }}$ century, the sheriffs had lost most of their role as tax collectors and judges. ${ }^{65}$ Not least since Magna Carta 1215 prohibited sheriffs from hearing pleas of the Crown. ${ }^{66}$ Pulling (in 1854) wrote of the sheriffs of the city of London and Middlesex:

Their authority as criminal judges was taken away by Magna Carta, ${ }^{67}$ the portion of the revenue which they now have to collect is very inconsiderable, the modern system of the police has superceded their ancient duties of assembling the posse comitatus in cases of riot, and the custom of appointing deputies to act for them, both in their judicial and executive capacity, has removed their responsibility in other respects.... ${ }^{68}$

The Local Government Act 1888 provided that the sheriffs of the City should have no authority except in the City. It also ended the right of the mayor, commonality and citizens of the City to elect the sheriff of Middlesex. ${ }^{69}$ Today, the position as to the two sheriffs of the City is as follows:

- Such jurisdiction as they have is limited to the Square Mile. ${ }^{70}$ A high sheriff of Greater London covers London outside the City (this includes parts of several old counties, including Middlesex);

- The sheriffs are officers of the Corporation of the City of London and they are elected annually not by the citizens of London - as envisaged in the charters - but by the liverymen of the livery companies; ${ }^{71}$

See Birch, n 3, pp 21-3; (b) charter of Edward I of 28 May 1298 (it limited the maximum amount of the amercement of the sheriffs of London and Middlesex to the same as other sheriffs). See Birch, n 3, p 44; (c) 1st charter of Edward III of 6 March 1327 (the sheriffs to be amerced for the escape of thieves the same amount as other sheriffs on this side of the Trent, being 100s). See Birch, n 3, p 54. See also Norton, n 3, p 351-4 and Coke, n 12, vol 1, s 194 (nature of amercement).

61 'the sheriffs... shall not be compelled to take any oath at our exchequer, but upon the yielding of their accounts.' See Birch, n $3, \mathrm{p} 56$.

62 'the sheriffs...may lawfully have forfeiture of victuals, and other things and merchandises, according to the tenor of the charter thereof made to the said citizens.' See Birch, n 3, pp 56-7.

${ }^{63}$ See Appendix. There are some incidental references in later charters to the sheriffs such as their providing support to the mayor and aldermen when acting as JP's (see Appendix nos 39 \& 41). However, these references are not relevant today since the mayor and aldermen do not sit as JP's.

${ }^{64}$ An Act of 7 April 1748 for repealing all former Acts, Orders and Ordinances, touching the nomination and election of sheriffs of the City of London and County of Middlesex and for regulating and enforcing such nominations and elections for the future. It begins 'Whereas from time immemorial there have been, and of right ought to be, two sheriffs of this city, which said sheriffs, during all the time aforesaid, have constituted, and of right ought to constitute, one sheriff of the county of Middlesex: and whereas the sheriffwick of this city, and the sheriffwick of the said county of Middlesex have, from time immemorial, belonged and do of right belong, to the mayor and commonalty and citizens of the city of London...'. See Birch, n 3, p 295 et seq. For a prior Act of 1725, see ibid, p 275 et seq.

${ }^{65}$ Over time, the sheriffs of London did not sit as judges, this being left to legally qualified under (or deputy) sheriffs. Further, JP's gradually took over the duties of the sheriff, as did (from Elizabethan times), the Lord Lieutenant. See McKechnie, n 15, pp 311-3. Walker, n 27 (sheriff) 'from the mid-twelfth century, his jurisdiction was limited by the growth of the king's courts and he came to have the functions of conducting preliminary investigations of accused persons, trying minor offences and detaining greater offenders till the itinerant justices came. The development of the offices of coroner, local constable and, particularly of justices of the peace, all took away duties from the sheriffs and, from the time of the Tudors, the office was mainly ceremonial.' See also Pulling, n 3, p 133.

${ }^{66}$ Magna Carta 1215, c 17, 'No sheriff, constable, coroners, or others of our bailiffs, shall hold pleas of the Crown.' See McKechnie, n 15, p 304 and Stubbs, n 9, p 650. Thomas, n 21, p xiv maintained that, even before 1215, there no evidence that sheriffs ever dealt with pleas of the Crown such as their fellows did in the shire and that '[their] jurisdiction seems to have been of a minor character.'

${ }^{67}$ See $\mathrm{n} 66$.

${ }^{68}$ See Pulling, n 3, p 133. McKechnie, n 15, p 313 wrote (in 1914), 'The fall of the sheriff was thus gradual...From presiding...over all the business of the district - financial, administrative, military, and judicial - the sheriff has become, in England at the present day, a mere honorary figure-head of the county executive... The real duties of his office are now performed by subordinates. What really remains to him is an empty and expensive honour, usually shunned rather than courted.'

${ }^{69}$ See 51 \& 52 Vict c 41 (1888), ss 41(8) 'The sheriff of the City of London shall not have any authority except in the City.' Also, s 46 (6), the 'right of the mayor, commonalty, and citizens of the city of London to elect the sheriff of Middlesex shall cease.'

${ }^{70}$ The sheriffs are elected annually by acclamation unless a ballot is demanded. It is a requirement for the Lord Mayor of London to have served as sheriff (this was stipulated by an Act of Common Council in 1385). See also COL, n 3, p 11. 
- The duties of the two sheriffs are wholly ceremonial (as noted in 1837); all their legal duties are performed by the Secondary. ${ }^{72}$ Thus, the sheriffs: (a) assist the mayor; (b) present petitions to Parliament - the latter last being exercised in 1948 (so it seems) $;^{73}$ and (c) attend the judges at the Central Criminal Court also called the Old Bailey - it being the court for the City and Middlesex. However, they do not take part in cases or pass judgment. ${ }^{74}$

Given this, it is asserted that the provisions of the above charters in so far as they relate to the sheriffs are obsolete, for the following reasons:

- The City and Middlesex is no longer farmed to the sheriffs of the City and Middlesex for $£ 300{ }^{75}$ with the result that the absolute estate, and interest, in the office of sheriff is not held by the sovereign but by the City. ${ }^{76}$ Further, Middlesex is no longer part of the Square Mile; the sheriffs having had no jurisdiction there since $1888 ;{ }^{77}$

- The sheriffs no longer perform a judicial function and have long not done so. The sheriff's courts in the City and Middlesex ceased operating in 1977 (see 4). Without a judicial, or tax gathering function, the sheriffs no longer collect fines for unsound victuals; nor are they liable for amercement up to $£ 20$, as mentioned in the charters. ${ }^{78}$ These provisions in the charters are obsolete $;^{79}$

- The election of the sheriffs today, is not made pursuant to any charter and has not been since 1725 . The sheriffs are not elected by the citizens of London (as envisaged by the charters) but by liverymen. ${ }^{80}$ Nor do they appoint deputies for tax collecting or judicial purposes, which was what the original purpose of having deputies was; ${ }^{81}$

- The charter of king John of $1199^{82}$ made the sheriffs responsible to the barons of the exchequer. This applied when the sheriffs collected taxes. However, they no longer do so, and barons of the exchequer no longer exist - their court being amalgamated with the Queen's Bench in $1875 .{ }^{83}$

In conclusion, the wording in the charters of the City of London concerning sheriffs is obsolete. ${ }^{84}$

\footnotetext{
${ }^{71}$ Halsbury, n 1, vol 29(2), para 58. An Act of Common Council of 2 May 1878 repealed all former acts etc relating to the office of shrievalty and vested the right of election in the liveryman in Common Hall. See RC, n 14, vol 18, p 194.

${ }^{72}$ See CMC, n 14, pp 81, 86. The full title of the secondary is 'The Secondary and Under Sheriff and High Bailiff of Southwark.' He is appointed by the Common Council. See Halsbury, n 1, vol 29(2), para 58, n 60. Also, RC, n 14, vol 18, p 73. See also Halsbury, n 1, vol 42, para 1109 and Sheriffs Act 1887, s 33(4)(the Act applies to the sheriffs of London in the same way as it applies to high sheriffs of counties).

${ }^{73} \mathrm{COL}, \mathrm{n} 3$, pp 24, 26 (the sheriffs attend at the bar of the Commons accompanied by the City Remembrancer). There is no particular good reason why the sheriffs have this function since the mayor can also petition the sovereign and he is the more senior officer, ibid, pp 23-4.

${ }^{74}$ They sheriffs are resident for their year of office in the court complex of the Old Bailey. In Court no. 1 of the Old Bailey the principal chairs on the bench are reserved for them. See also Senior Courts Act 1981, s 8 (3) (Lord Mayor and alderman shall be entitled to sit as judges of the Central Criminal Court).

${ }^{75}$ Thus, they have to make no oath to the exchequer, see $\mathrm{n} 61$.

${ }^{76}$ The farm of $£ 300$ was redeemed by the City in 1929. See COL, n 3, p 25 'the absolute estate and interest in the office of sheriff now belongs to the Corporation [of London].' See also ibid, p 79; Pulling, n 3, p 539 and RC, n 14, vol 2, p 188. See also Halsbury, n 1, vol 42 para 1109 'The office is held of the Corporation, which is answerable to the Crown for its due execution on the part of the sheriffs and their officers.' The election of the sheriffs is approved by the Crown signified by warrants under the seal of the Chancellor of the Exchequer. Ibid, para 1110 and Sheriffs Act 1887, s 33(2).

${ }^{77}$ See n 69.

${ }^{78}$ Both are obsolete anyway. Norton, n 3, p 354 (in 1869) '[amercements have] entirely sunk into neglect.'

${ }^{79}$ See ns $62 \& 60$.

${ }^{80}$ Norton, n 3, pp 114, $126 \& 310$. In 1376, a change was made when the mayor elected one sheriff and the commonalty another. This gave rise to endless disputes, see Sharpe, n 30, vol 2, p 470 et seq, which were not resolved until 1725, see n 64.

${ }^{81}$ See $\mathrm{n} 58$. Despite the provision on two deputies in the charter of John of 1199, their number was regulated early on by way of civic ordinance and increased from two, see Norton, n 3, p 338. Also, Riley, n 3 (Munimenta, Liber Albus III), p 64.

${ }^{82}$ viz. "we have granted...to our citizens of London, the sheriffwicks of London and Middlesex, with all the customs and things to the sheriffwick belonging, within the city and without, by land and by water...that they amongst themselves make sheriffs whom they will; and may amove them when they will; and those whom they make sheriffs, they shall present to the justices of our exchequer, of these things which to the said sheriffwick appertain, whereof they ought to answer to us.' (italics supplied in respect of obsolete wording). See text to n 54 .

${ }^{83}$ Norton, n 3, p 312. See also Baker (2002), n 52, p 51.

${ }^{84}$ The only wording which is, possibly, not obsolete is that which relates to the liberty to elect sheriffs granted by the Crown, see n 82 above. If necessary, the Sheriffs Act 1887 s 33 could be amended to provide that 'The Corporation of London shall continue to elect two sheriffs annually.' How they elect and remove them is an internal matter which can be regulated by Act of Common Council. Cf. n 76 .
} 


\section{Liberty - Court of Hustings and Sheriff's Court}

After Magna Carta 1215 prohibited sheriffs from trying pleas of the Crown, ${ }^{85}$ the City sheriffs were restricted to being judges in the two principle London courts existing at that time - the court of Hustings and the sheriff's court (folkmote). A charter of Henry I of c. 1155 refers to these courts when it provides that there:

shall be no more miskenning in the hustings, nor in the folkmote [sheriff's court], nor in any other pleas within the city; and the hustings may sit once a week, that is to say, on Monday. ${ }^{86}$

Miskenning (mis-counting) was the change in a plea or count such as when a person left off his first plea, or declaration, and gave another. ${ }^{87}$ More particularly, it referred to a court fine that was required to be paid when a mistake was made in the set formula of Anglo-Saxon pleading - these accrued to the sheriffs of the City and Middlesex. ${ }^{88}$ Subsequent charters to London also refer to miskenning. ${ }^{89}$ Thus, this charter abolished miskenning in the London courts where it had, doubtless, been used as a money-making device. ${ }^{90}$ As to the courts referred to in respect of miskenning - the court of hustings and the sheriffs court - they no longer operate today. The position is as follows:

- Court of Hustings. ${ }^{91}$ Hustings probably derived from the Anglo-Saxon word, house (hus) the composite word meaning a 'house thing', being an assembly of the retainers of the king with 'thing' being a reference to a cause or law suit. This court was the highest court of the city. Existing at least from the $10^{\text {th }}$ century, ${ }^{92}$ it comprised a court of record held at the Guildhall with the mayor, sheriffs and aldermen as judges. ${ }^{93}$ The court of Hustings dealt with all pleas within the City which were not pleas of the Crown. It met in two forms: (a) Hustings of pleas of land (which handled writs of right patent directed to the sheriff of London); and (b) Hustings of common pleas (which handled other writs). As this court developed historically, the judges became the mayor, the sheriffs and the recorder - with the recorder directing the mayor and sheriffs on points of law and delivering judgment. ${ }^{94}$ Thus, the first two became only,

${ }^{85}$ See $\mathrm{n} 66$.

${ }^{86}$ Birch, n 3, p 4. Cf. Robertson, n 21, p 291 (alternative translation) 'And further there shall be no 'miskenning' in a husting or a public meeting or in any other courts inside the city. And the hustings shall sit once a week, namely on Monday.'

${ }^{87}$ OED n 26 (miskenning), 'A miskenning or variation in pleading before a court. Also, a fine exacted for this.' Robertson, n 21, p 374 'The meaning is that advantage is no longer to be taken of a mistake in pleading. Formerly, if detected, it might lead to the infliction of a heavy fine by the court or might be used by the pleader's opponent to gain a judgment in his own favor.' Downer (1972), p 337 'the fine payable for permission to amend, hence a source of revenue.' See also Norton, n 3, pp 294-7 and Riley, n 3 (Munimenta, Liber Custumarum, pt 2), p 743. See also Ballard, $\mathrm{n} 5$, p lxiii who notes that a number of boroughs were granted freedom from this (see pp 146-8).

${ }^{88}$ Bateson, n 5, vol 21, p cl, 'It was an ancient principle that the word once uttered in court could not be withdrawn. Whoever said the wrong thing, or failed to observe the forms precisely, could not recall what he had said or seek to improve upon his statement. His opponent, or the judge, or any member of the court could use against him his 'mislocutio', his 'stultiloquium,' his 'miskenning.' ... The mistake made in the plea, if detected by a member of the court, was on his challenge submitted to judgment, to give the court an amercement; or the opponent himself could take the speaker at his word, and secure for himself a judgment thereon.' See also Ibid, pp 1, 4.

${ }^{89}$ (a) charter of Henry II ('there shall be no miskenning in any plea within the city: and that the hustings shall be kept once a week'). See Birch, n 3, p 5; (b) $1^{\text {st }}$ charter of Richard I of 23 April 1194 ('there be no miskenning in any place within the city; and that the hustings be kept only once a week.'). See Birch, n 3, p 7; (c) $1^{\text {st }}$ charter of John of 17 June 1199 ('there shall be no miskenning in any plea in the city: And that the hustings shall be kept once a week'). See Birch, n 3, p 11; (d) $4^{\text {th }}$ Charter of Henry III of 16 March 1227 ('no miskenning be in any pleading in the city; and that the hustings be kept only once a week.'). See Birch, n 3, p 28; (c) $8^{\text {th }}$ charter of Henry III of 26 March 1268 ('We have also granted to them, that the hustings might be kept in every week once the week, and that only for one day; or as notwithstanding that those things within the same day cannot be determined, may continue till the next morning, and no longer...and they may not be questioned as miskenning in any their pleas; that is to say if they have not declared altogether well.)' See Birch, n 3, p 40.

${ }^{90}$ The court of Hustings still had other severe rules of pleading, as noted by Bateson, $\mathrm{n} 5, \mathrm{vol} 2, \mathrm{p}$ cli. These rules were abolished long before the court itself became obsolete.

${ }^{91}$ Husting is sometimes in the singular and sometimes in the plural.For this court, see generally, Bohun, n 1, pp 228-50; Jacob, n 3, pp 55-8, Anon, n 3, pp 143-61; Pulling, n 3, pp 170-77. See also Thomas, n 21, pp xiii-iv (who discusses the relationship of this court with the sheriff's court and mayor's court). See also Riley, n 3 (Munimenta, Liber Albus III), p 17.

92 Thomas, n 21, p xiii. See also Stenton, n 20, p 539-40 and Coke, n 12, vol 4, p 327.

${ }^{93}$ The aldermen met weekly in the court of Hustings and, probably, the court of Alderman developed from the administrative side of this court. This gave rise to the Court of Aldermen having an inner and an outer court, which expression continues today.

${ }^{94}$ Pulling, n 3, p 170 (in 1854), 'The presiding judges are the lord mayor and sheriffs...The recorder, however, although not technically considered a judge of the court, always attends as assessor to the presiding judges, to examine the witnesess and deliver the judgments; and...is exclusively empowered to pronounce the judgment.' Also, p 118. 
nominally, judges. This court also served as a court of probate and of registry of wills (albeit no wills were registered since 1688) and as a registry of deeds (enrolment in the same was sufficient evidence in a court of law of title to property in the case of a lost deed and it had the same force and effect as a fine at common law). The court of Hustings was obsolete even by $1858,{ }^{95}$ although it last sat (as such) in 1965 (for the recording of land deeds). Although not formerly abolished, it can no longer sit after 1977 and it is effectively obsolete; ${ }^{96}$

- Sheriff's Court ${ }^{97}$ A court of record at the Guildhall, this court was presided over by the sheriffs of London and Middlesex. It tried: actions of debt, case, trespass, account, covenant and all personal actions, attachments and sequestrations. The court of Hustings being a superior court, it could reverse erroneous judgments of the sheriff's courts (this was abolished in 1852). ${ }^{98}$ There were still two sheriffs courts (treated as one) when Pulling wrote in $1854 .{ }^{99}$ In 1867 , the sheriff's court was united with the mayor's court (see below) under the new title of the City of London Court of Husting and Sheriff's Court (City of London court). ${ }^{100}$ No judges were appointed to them after 1929 and, although they have not been formerly abolished, after 1977 it can no longer sit and are obsolete, ${ }^{101}$

- Folkmoot (Folkmote). In the case of London, the folkmote comprised a general assembly of all the citizens. It met three times a year, assembling on land on the east side of old St Paul's - the citizens being summoned by the great bell in the Tower of St Pauls. ${ }^{102}$ When the last London folkmoot met is unclear but it was likely in the reign of Edward III (1327-77). ${ }^{103}$ However, the folkmote was also a court - the regular tribunal for determining of all felonies - it later became the sheriff's court, for which see above. ${ }^{104}$ As for other courts in the City besides the above, over the centuries there had been many courts (or quasi-courts, since the appellation of 'court' in the title did not mean a legal court but a gathering of people) existing in London at one time and another, viz

- Mayor's court ${ }^{105}$

- Court of orphans abolished in 1971; ${ }^{106}$

it became obsolete after $1724 ;{ }^{107}$

95 'Allen, n 3, p 25 ' [it] does not now sit, and all the business formerly transacted at it is transferred to the Lord Mayor Court and the City Small Debts Court.' RC, n 14, vol 18, p 373 (in 1894) 'practically obsolete.' RC-54, n 14, p xxxvii (should be abolished).

${ }^{96}$ Halsbury, n 1, vol 10, para 855 n 4. The Administration of Justice Act 1977, s 23(1) provides that the court of Hustings shall cease to have jurisdiction to hear and determine legal proceedings but can still continue to sit and transact such other business, if any, as was customary for it immediately before the coming into force of that section (ie the enrolment of wills and title deeds to land). This latter function is now also obsolete. See generally, McBain (2012a) for this court and the sheriff's court.

${ }^{97}$ See generally, Thomas, $\mathrm{n} 21$, p xiv et seq; Bohun, n 1, pp 300-12; Jacob, n 3, pp 52-3; Anon, n 3, pp 170-3 and Pulling, n 3, pp 200-3. The sheriffs were represented by under (or deputy) sheriffs, skilled in law. See Harrison (1860).

${ }^{98}$ COL, n 3, p 82 and London (City) Small Debts Act 1852. See also RC, n 14, vol 18, p 54.

99 Pulling, n 3, pp 200-3 'The two sheriffs of London have nominally each a court of record under them....and which are now called compters, probably like the word county from comes...The courts are holden separately at different places and designated as 'the sheriffs' court, holden for the Giltspur Street or the Poultry Compter,' as the case may be... at present one judge [ie. a district judge or deputy sheriff appointed by the court of common council] acts for both divisions... Though the sheriffs are the nominal judges...they never at this day preside.' At this stage the sheriff's court handled small debts. See also Allen, n 3, p 25 (in 1858).

${ }^{100}$ COL, n 3, p 85. See also RC, n 14, vol 18, p 52.

${ }^{101}$ Halsbury, n 1, vol 10, para 855, fn 4. See also Administration of Justice Act 1977, s 23(1).

${ }^{102}$ See Stubbs, n 3, p 313 (Londoners were fined 40s for failing to attend any of the annual folkmoots). See also Gomme, n 3 , p 354.

${ }^{103}$ For meetings of the London folkmoot in 1257, 1259, 1271, see Riley, n 3 (Chronicles), pp 33, 37, 45. Also, Sharpe, n 30, vol 1, p 90 and Norton, n 3, p 74 .

${ }^{104}$ Pulling, n 3, p 170 'The two courts in existence in each county in the time of the Saxons were the folkmote for criminal causes, now called the sheriff's tourn or leet, and the sciremote [shire moot] for civil suits, and similar courts, under the name of the hustings and folkmote, are mentioned in the earliest of the London charters.' Also, p 208 'The folkmote...was the regular tribunal for inquiring and determining of all felonies.' See also RC, n 14, vol 18, p 41.

${ }^{105}$ This was a court of record and of law and equity held daily at the Guildhall. It was also called the court of Aldermen of the outer chamber. From the 14th century, the recorder of the City was the sole presiding judge (although the mayor and aldermen could, technically, sit as judges but did not do so). All manner of actions to any value could be tried for any matters arising within the City. See generally, Anon, n 3, pp 161-70; Bohun, n 1, p 250 et seq; Jacob, n 3, pp 47-51; Pulling, n 3, pp 177-200; RC n 14, vol 2, p 47 and COL, n 3, p 88. See also Daly (1861) and Glyn (1910).

106 The court was amalgamated with the City of London court (sheriff's court) in 1921 pursuant to the Mayor's and City of London Courts Act 1920 which court was abolished by the Courts Act 1971, s 42 and replaced by a county court that retained, in part, its old name (it is called the Mayor's and City of London Court). See RC, n 14, vol 18, p 373 and COL, n 3, p 85. 
- Chamberlain's court

- Court of Common Council

- Inner court of Aldermen

- Court of wardmote

- Court of the Thames

- Court of requests

- Court of hallmote

- Court of the coroner;

- Court of the Tower of London;

- Court of St Martin's-le-Grand

- Court of the Escheator. this court still exists, but is long obsolete; ${ }^{108}$

a legislative body, not a court; ${ }^{109}$

the outer court was the court of Hustings; ${ }^{110}$

a court leet, defunct from $1977 ;^{111}$

superceded by the Thames Conservancy in $1867 ;^{112}$

superceded by the county courts in $1864 ;^{113}$

not a court as such, a meeting of livery companies; ${ }^{114}$

obsolete, legislation now applies; ${ }^{115}$

obsolete; ${ }^{116}$

abolished, in effect, in $1857 ;^{117}$

obsolete $^{118}$

${ }^{107}$ This was a court held before the mayor and aldermen of the City. They were guardians to the children of all freemen under 21 years at the time of their father's death. The court met once a year to hear the names of all securities that stood bound for orphans' portions called over. See generally, Coke, n 12, vol 4, p 248; Bohun, n 1, pp 313-36; Jacob, n 3, pp 65-6 \& 121-5; Anon, n 3, pp 174-8. Pulling, n 3, p 196 described this court (in 1854) as being in disuse, mainly as a result of 5 Will \& M c 10 (1694). Its functions were taken over by Chancery.

${ }^{108}$ This court (it is also described as an office) was administered by the Chamberlain for hearing, and determining, disputes between apprentices and their masters. See Bohun, n 1, pp 337-76, LL, n 3, pp 250-7; Jacob, n 3, p 64; Anon, n 3, pp 192- 3; Pulling, n 3, p 124. Also, Halsbury, n 1, vol 10, para 858; RC, n 14, vol 18, pp 375-6 and COL, n 3, pp 90-2. In 1894, it was recommended that this court be abolished, see RC, n 14, vol 18, p 541. See also McBain (2012), pp 35-6.

${ }^{109}$ This still exists as the legislative and executive body of the City. See Halsbury, n 1, vol 29(2), paras 51- 5. See also CMC, n 14, p 69.

${ }^{110}$ This still exists as a court of record and it exercises jurisdiction over the livery companies. See Halsbury, n 1, vol 29(2), para 47-50. The inner court is called the Court of the Mayor and Aldermen of the Inner Chamber. See also CMC, n 14, p 67.

${ }^{111}$ A court of record, like a court leet, it was held by the aldermen of the several wards of the City. Derived from the Lord Mayor's court it corrected defects and disorders, remove annoyances and promote the common interest. Pulling, n 3, p 219 noted that, the criminal jurisdiction of the wardmote court having been taken away by Magna Carta (see n 66), 'henceforth the wardmote court had only power to inquire into offences, and present them to superior tribunals - a power which it nominally exercises at the present day, under the ancient articles of wardmote inquest...' See generally, Bohun, n 1, pp 383-92; Jacob, n 3, p 63; Anon, n 3, pp 185-92; Pulling, n 3, pp 218-21. Courts leet no longer operate (with limited exceptions) pursuant to the Administration of Justice Act 1977, s 23(1). Wardmotes inquests were abolished in 1856, see Halsbury, n 1, (3rd ed, 1952), vol 9, para 1133. Wardmotes still meet but are limited to electoral matters. See Halsbury, n 1, vol 29(2), para 51.

112 This court (Court of Conservancy for the river Thames) was held before the mayor (accompanied by the recorder) within the respective counties near adjacent to the cities of London and Westminster and adjoining to the Thames. It punished encroachments on the river. See generally, Bohun, n 1, pp 393-427; Jacob, n 3, p 66-7; Anon, n 3, pp 180-2; Pulling, n 3, pp 325-6. In 1857, jurisdiction over the Thames was transferred to the Thames Conservancy. Today, the Thames is managed by the Environment Agency.

113 This court determined matters between citizens in cases where the debt, or damage, did not exceed 40s (later increased to $£ 10$ ). A $1^{\text {st }}$ charter of Charles I of 18 October 1638 (see Appendix, no 41) constitutes a clerk and a beadle to this court. See generally, Bohun, n 1, pp 428-37; Jacob, n 3, pp 58-60; Anon, n 3, pp 182-5 and Pulling, n 3, p 203-7.

${ }^{114}$ See Halsbury, n 1, vol 29(2), para 56. Bohun, n 1, p 438, 'The Halmote, or Court of the Hall, is that court which every company in London keep in their halls, which was anciently called the halmote or folkmote.' See generally, Coke, n 12, p 249; Jacob, n 3, p 64; Anon, n 3 , p 193 and Pulling, n 3, p 388.

${ }^{115}$ The mayor (in theory) presided over this court. However, when Pulling wrote (in 1854), it was presided over by a coroner elected by the Common Council. See generally, Bohun, n 1, p 438; Jacob, n 3, p 66; Anon, n 3, pp 179-80 and Pulling, n 3, pp 128-9.

116 This court was held within the verge of the Tower of London before the steward, by prescription, for debt, trespass, and other actions of any sum greater or lesser. See generally, Coke, n 12, vol 4, p 250; Bohun, n 1, p 438; Jacob, n 3, p 67 and Anon, n 3, p 196. It is not mentioned by Pulling (in 1854).

117 This court was originally subject to the liberty of the deanery of Westminster. Parties dissatisfied with a decision of the court of Hustings could have a writ returnable before this court before certain commissioners (usually 5 of the judges of the superior courts) from whose judgment a writ of error lay to the House of Lords, as a last resort. Pulling, n 3, pp 173-4 (in 1854), 'The proceedings upon this commission being extremely expensive, it has rarely been resorted to in modern times.' See also Bohun, n 1, p 439; Anon, n 3, p 195; Jacob, n 3, p 67, and COL, n 3, p 83, 87. Appeal from the court of Hustings was later transferred to the Exchequer Chamber (and later, to the Queen's Bench division). See the Mayor's Court of London Procedure Act 1857, s 4. See also RC, n 14, vol 18, pp 47 \& 195; CMC, n 14, p 135 and COL, n 3 , p 87. In 1854, the Commissioners recommended that it be abolished, see RC-54, n 14, p xxxvii.

${ }^{118}$ This court was held before the mayor. The escheator was the officer who looked after the lands or profits that fell to the sovereign by forfeiture or death. The mayor is perpetual escheator within the city and Southwark, see 8.2. See generally, Jacob, n 3, p 66; Anon, n 3, p 180 and Pulling, n 3, p 19. 
All the above courts have now been abolished or are obsolete ${ }^{119}$ apart from the courts of Common Council, the court of Hallmote (Common Hall) and the court of Aldermen (inner court) - all of which do not sit as judicial courts.

In conclusion, the wording in the charters relating to the folkmote (ie.to the sheriff's court) and the court of hustings are obsolete since these courts no longer operate. Nor does the Anglo-Saxon fine for miskenning.

\section{Liberty - To Be Tried within the City Walls}

As a result of their freedom to elect sheriffs - and the presence in London of the sheriff's court and court of hustings - the citizens of London secured the liberty to be tried 'within the walls' of the City. This liberty was, in effect, an exemption from external jurisdiction in respect of civil and criminal matters. ${ }^{120}$ At that time this liberty was secured, the reference to the 'walls' was apposite, since London was enclosed by defensive walls of some 2 miles in circumference as well as by a moat. ${ }^{121}$ The charter of Henry I of 1132 provides:

the citizens of London shall not plead without the walls of London for any plea....if any one of the citizens shall be impleaded concerning the pleas of the crown, the man of London shall discharge himself by his oath, which shall be adjudged within the city. ${ }^{122}$

This reference to citizens discharging (purging) themselves by oath (that is, by wager of law) was that they did not have to undergo trial by battle, see $6 .{ }^{123}$ Similarly, a charter of Henry II of c. 1155 provides:

I have granted to my citizens of London, that none of them shall plead without the walls of the city of London, upon any pleas, except only pleas of foreign tenures (my moneyers and officers excepted)... And of the pleas of the Crown they may discharge themselves, according to the old usage of the city [ie. by oath see charter of Henry I above]. ${ }^{124}$

Thus, the citizens of London were entitled to be tried by their own courts except in: (a) cases relating to land outside the City; (b) cases relating to the king's own officers or officials of the mint ('moneyers'). This liberty was confirmed in subsequent charters ${ }^{125}$ although the number of exceptions was also expanded. Thus, an $8^{\text {th }}$ Charter of Henry III of 26 March 1268 provides:

none of them be compelled to plead out of the walls of the said city, for anything except foreign tenures, and except our moneyers and officers, and except those things which shall happen to be done against our peace, which according to the common law of our realm, are wont to be determined in the parts where those trespasses were done; and except pleas concerning merchandises, which are wont to be determined according to the law merchant in boroughs and fairs [ie. by courts of piepowder], so yet notwithstanding that those plaints be determined in the boroughs and fairs, by four or five of the said citizens of London, ${ }^{126}$ who shall be present; saving to us the amerciaments in any wise coming, which they shall faithfully answer us and our heirs, upon pain of grevious forfeitures.

\footnotetext{
${ }^{119}$ For the nature of these courts in their prime see Emerson (1794). Also, Brandon (1876).

${ }^{120}$ Stubbs, n 3, p 46 'exemption from external judicature...and protection for the lands and rights of the citizens, who were entitled to the benefit of their local customary law, even if they were appealed to the king's court.' Also, $p 439$.

${ }^{121}$ In 1132, London was a walled city with a population of c. 18,000 people. For a map of how London looked like in the 13th century, see Green (1893). For one c.1381 see Bird (1949), Appendix. For one in Tudor times, see Gomme, n 3, p 369 and for one c. 1598, see Stow, n 3. For one in 1884, see Owen, n 14, pp 34-5. For details of the limits of the City in 1837, see CMC, n 14, pp 1-4.

${ }^{122}$ Birch, n 3, p 3. For the oaths by wager of law, see Bateson, n 5, vol 1, pp 39, 45, 47.

${ }^{123}$ Noted by Sharpe, n 30, vol 1, p 41. See also Norton, n 3, pp 285-6 (who notes that only those who were freemen and 'law worthy' could wage law).Wager of law became obsolete by the 17th century and was finally abolished by the Civil Procedure Act 1833 , s 13.

${ }^{124}$ Birch, n 3, p 5. See also Gomme, n 3, p 258. For foreign tenures and moneyers, see Norton, n 3, p 302.

${ }^{125}$ (a) $1^{\text {st }}$ charter of Richard I of 23 April 1194, ('none of them may plead without the walls of the city of London, for any pleas, saving pleas of foreign tenures, except our moneyers and ministers... and that they may discharge themselves of pleas belonging to the Crown according to the ancient custom of the city').[ie by oath]. See Birch, n 3, pp 7-8. (b) $1^{\text {st }}$ charter of John of 17 June 1199, ('none of them shall plead without the walls of the city of London, any pleas, saving the pleas of foreign tenures, our moneyers and ministers excepted...and of pleas belonging to the Crown they may discharge themselves according to the ancient custom of the city'). See Birch, n 3, p 11; (c) $4^{\text {th }}$ Charter of Henry III of 16 March 1227 ('none of them shall plead without the walls of the city of London, saving the pleas of foreign tenures, our moneyers and ministers excepted'). See Birch, n 3, p 28.

${ }^{126}$ See also Bateson, n 5, vol 2, p 185. A 1st charter of Charles I of 18 October 1638 provides, 'And forasmuch as the citizens, in all good fairs of England, were wont to have among themselves keepers to hold the pleas touching the citizens of the city assembling at the said fairs: we will and grant, as much as in us, that the same citizens may have such like keepers, to hold such pleas of their covenants, as of ancient time they had, except the pleas of land and of the crown.' See Birch, n 3, p 187.
} 
Also,

and that for the pleas belonging to the Crown, chiefly those which may chance within the said city and suburbs thereof, they may discharge themselves according to the ancient custom of the said city. [ie. by oath]. ${ }^{127}$

Caselaw may be found in 1258, 1260, 1273 where London citizens successfully resisted being impleaded outside London. ${ }^{128} \mathrm{~A} 1^{\text {st }}$ charter of Edward III of 6 March 1327 provides that:

no summons, attachments, or executions be made by any of the officers whatsoever of us or our heirs [ie, by Crown officers], by writ, or without writ, within the liberty of the said city; but only the ministers of the said city [ie. by officers of the City]. ${ }^{129}$

This liberty - which was also given to other towns and cities - was directly linked to the fact that the City possessed its own specialised courts with their own distinct procedure. In particular, the sheriff's court and court of hustings. As it is, the City substantially expanded beyond its walls in Tudor times. Also, the specialised courts to handle the pleas of citizens have been superceded (see 4). ${ }^{130}$ Today, the Square Mile is not bounded by walls. Nor do the specialised courts exist. Thus, this liberty has no meaningful effect, or benefit. ${ }^{131}$

In conclusion, this liberty to be tried 'within the walls' is long obsolete.

\section{Liberties - Penalties and Fines}

As well as the liberty of being tried 'within the walls', the citizens of London secured - by charter - the liberty of being free from a criminal fine levied on the community arising from the unsolved murder of non-Englishmen (murdrum). Further, they were not forced to wage battle (a Norman invention) as a means of resolving legal disputes. Thus, the charter of Henry I of 1132 provides that the citizens:

shall be free... of all murder; and none of them shall wage battle. ${ }^{132}$

As to these,

- Murdrum. This was also called 'acquittal of murder'. As Maitland notes, under the law of William I (1066-87), the hundred paid a fine when a foreigner (ie. a non-Englishman) was slain and the slayer was not produced. ${ }^{133}$ This fine, and the cause were, alike, known as 'murdrum. ${ }^{134}$ This form of punishment likely derived from Anglo-Saxon law. ${ }^{135}$ Thus, citizens of London were exempted from this fine. A $1^{\text {st }}$ charter of Richard of 23 April 1194 extends the freedom from murdrum to the 'Portsoken' ${ }^{136}$ which

\footnotetext{
${ }^{127}$ See Birch, n 3, pp 38-9 and Riley, n 3, (Chronicles), pp 107-9.

${ }^{128}$ Riley, n 3, (Chronicles) p 42 (men of Southwark and Surrey complained to the justiciars at St Saviour's of tolls imposed on them on London Bridge. The citizens of London contended that no one but the sheriffs could hold pleadings in the City as to trespasses there committed) See also, pp 49-51 (London citizens involved in an affray were seized by bailiffs of the town of Northampton). Also, p 167 (the prosecution of a London sheriff for bribery). See also Letterbook D, n 3, p iii (a London citizen accused of felony in 1309) and p 290 (an escheat of a tenement in 1312).

${ }^{129}$ See Birch, n 3, p 56. It continues, 'none of the freemen of the said city shall be impleaded or troubled at our exchequer, or elsewhere by bill, except it be by those things which touch us or our heirs.' Also, 'the marshal, steward or clerk of the market of our household, may not sit from henceforth within the liberty of the aforesaid city, nor exercise any office there, nor any way draw any citizen of the said city to plead without the liberties of the said city, of any thing that may happen within the liberties of the said city.' See Birch, n 3, p 55.

See also a Proclamation made on 11 September 1383 cited by Birch, n 3, p 71.

${ }^{130} 11 \mathrm{Geo} 1 \mathrm{c} 18$, s 19 (1724) provided for the oath of freedmen to exclude the words 'Ye shall implead or sue no freeman out of the city whilst ye may have right and law within the same city.' See Birch, n 3, p 289. See also Norton, n 3, p 278.

${ }^{131}$ Norton, n 3, p 277 (in 1869) 'under the present administration of the law, it happily no longer confers any advantage.' Bacon, n 11, vol 2, p 247 (in 1798) noted that, despite the liberty, a writ of certiorari lay to remove any indictment from London.

132 Birch, n 3, p 3.

${ }^{133}$ Pollock (1984), vol 1, p 89. See also Blackstone, n 2, vol 4, p 195 and Norton, n 3, pp 283-4.

${ }^{134}$ Ibid, n 133, vol 2, p 487 'This fine and its cause were alike known as a murdrum: it was a fine occasioned by a secret homicide, a homicide secret in this sense that no one was brought to justice as its author...The original murdrum was a sum of 46 marks, of which 40 went to the king, 6 to the kinsfolk of the slain; but our earliest rolls show us that this must have been a crushing penalty, for the sums actually demanded are much smaller; no part of them, so far as we can see, goes to the kinsfolk.' See also Bohun, n 1, p 36.

${ }^{135}$ O’Brien, n 21, pp 77-8, 175.

${ }^{136}$ Birch , n 3, p 7, 'acquittal of murder within the city, and in [the] portsoken.' See also: (a) $1^{\text {st }}$ charter of John of 17 June 1199 ('acquittal of murder, within the city and portsoken'). See Birch, n 3, p 11; (b) $4^{\text {th }}$ charter of Henry III of 16 March 1227 ('acquittal of all murder within the city and portsoken'). See Birch, n 3, p 28; (c) $8^{\text {th }}$ Charter of Henry III of 26 March 1268 ('acquittal of murder in the said city and in
} 
refers to the extended jurisdiction of the City from outside the gates of the City in the vicinity of Aldgate. ${ }^{137}$ Murdrum was abolished in 1340, although it was obsolete, in any case, by the time of Henry II $(1154-89) ;{ }^{138}$

- 'Trial by battle' or 'Wager by battle'. Judicial duel was introduced into England by the Normans as a means of resolving certain civil cases. ${ }^{139}$ More particularly, it was used in criminal cases when a person made an accusation against another by way of an appeal of murder, treason or felony. ${ }^{140}$ The battle occurred in the presence of the robed judges of the Queen's Bench or Common Pleas and it continued until one of the parties was killed or surrendered. If the party defeated was the accused, he stood convicted of the crime. If the accuser, the accused was adjudged innocent. This freedom of the citizens of London from trial by battle was repeated in later charters. ${ }^{141}$ Trial by battle was condemned at the Fourth Lateran Council in 1215 and it was practically obsolete by the end of the $13^{\text {th }}$ century, although it was not formally abolished until $1819 .^{142}$

These were not the only liberties. A charter of Henry II of c. 1155 provides that the citizens:

shall be free and quit of bridtoll, childwite, jeresgive, and scotale; so as the sheriff of London, or any other bailiff may take no scotale. ${ }^{143}$

In respect of these:

- Bridtoll (Bridgetoll). This was the obligation to repair a bridge. ${ }^{144}$ In the case of London, the only bridge over the Thames in medieval times was London Bridge (built of stone in 1209). The Anglo-Saxon 'bridtol' was superceded by the Norman 'pontage' now, itself, obsolete, ${ }^{145}$

- Childwite (Childwit). This was a fine paid by a man to his lord for unlawfully impregnating his bond women. ${ }^{146}$ It was also called letherwite (leirwite). ${ }^{147}$ It is long obsolete (as is the status of villeinage), although precisely when childwite ended is unclear, ${ }^{148}$

portsoken.'). See Birch, n 3, p 39. Also, Bohun, n 1, p 37.

${ }^{137}$ The Portsoken (soke of the Port) comprised land occupied by the soke of the Cnichtengild (an anglo-saxon guild of knights) which merged with that of the priory of Holy Trinity, Aldgate (the guild was extinguisehd as a result, see Ballard, $\mathrm{n} 5, \mathrm{p}$ lviii). This area of land later became the Portsoken Ward without Aldgate. See Stow, n 3, p 110; Riley, n 3 (Chronicles), p 107; LetterBook C, n 3, p xxv et seq; Jacob, n 3, p 100 and Norton, n 3, pp 291, 302-3. See also Riley, n 3 (Munimenta, Liber Custumarum, pt 2), p 821. For sokens in London, see Ballard, n 5, pp 126-9. ${ }^{138}$ See 14 Edw III st 1 c 4 (1340). Walker, n 27 (murdrum), 'In medieval English law, secret homicide. Legislation of William I [1066-87] required the hundred to pay the murder fine of whenever a dead body was found within its limits which could not be proved to be that of an Englishman and the delinquent was not produced. In 1340, the murder fine was abolished and the term reverted to meaning the most serious form of homicide, killing with malice afterthought.' Stubbs, $\mathrm{n} 9, \mathrm{p} 413$ 'The commixture of the populations had so far proceeded in the time of Henry II [1154-89] that it was imposible to decide the question of nationality, and all murders were punished alike.' See also Bateson, $\mathrm{n} 5$, vol 1, p 33-4 and Maitland, n 3, vol 2, p 482

${ }^{139}$ Blackstone, $\mathrm{n} 2$, vol 3, p 337 et seq (he asserts the last occasion of trial by battle in a civil case was in 1571). See also Baker, n $52, \mathrm{p} 74$.

${ }_{140}$ Walker, n 27, (trial by battle). See also Blackstone, n 2, vol 4, pp 340-2; Robertson, n 21, p 374; Stubbs, n 9, p 299 and Norton, n 3, pp $284-5$. ${ }^{141}$ (a) $1^{\text {st }}$ charter of Richard I of 23 April 1194 ('that none of them may wage battle'). See Birch, n 3, p 7; (b) 1st charter of John of 17 June 1199 ('none of them shall wage battle'). See Birch, n 3, p 11, (c) $4^{\text {th }}$ charter of Henry III of 16 March 1227 ('none of them shall wage battle'). See Birch, p 28; (d) $8^{\text {th }}$ Charter of Henry III of 26 March 1268 ('none of the said citizens may wage battle'). See Birch, n 3, p 39.

14259 Geo III c 46 (1819). This was subsequent to Ashford v Thornton (1819) 1 B \& Ald 405 (106 ER 149) (appeal of felony).

${ }^{143}$ See Birch, n 3, p 6. See also: (a) $1^{\text {st }}$ charter of Richard I of 23 April 1194 ('they shall be free and quit of bridtoll, childwite, jeresgive, and scotale; so as the sheriff of London, or any other bailiff may take no scotale.'). See Birch, n 3, p 8; (b) $2^{\text {nd }}$ charter of John of 17 June 1199 ('free and quit of all bridtoll and childwite, and of jeresgive and scotale, so that neither the sheriff of London, nor any other bailiff, may make any scotale.'). See Birch, n 3, p 12; (c) 4th charter of Henry III of 16 March 1227 ('quit from bridtoll, childwhite, jeresgive, and of all scotale, so that our sheriff of London, or any other bailiff, shall not make scotale.') See Birch, n 3, p 29; (d) 8th charter of Henry III of 26 March 1268 ('quit of childwite and jeresgive, and from scotale; so that our sheriffs of London, nor any other bailiff, shall not make any scotale.') See Birch, n 3, p 40.

${ }^{144}$ For the form of bridge toll in Anglo-Saxon times see Robertson, n 21, p 73 who refers to the Laws of Ethelred (978-1016) (a merchant who came to a bridge with a boat containing fish paid $1 / 2 \mathrm{~d}$ as toll and for larger ships $1 \mathrm{~d}$ ). For quittance of this obligation see Fleta (c 1290), Selden Society reports, vol 72, p 102 'Bridgebot, quittance of the duty of repairing a bridge.' See also Stubbs, n 3, p 509 (pontage); Bohun, n 1, p 34 and Norton, n 3, p 303. Also, Riley, n 3 (Munimenta, Liber Custumarum, pt 2), p 704.

${ }^{145}$ See McBain, n 4. Old London Bridge (1309-1832) was freed from toll in 1767 (see RC, n 14, vol 18, p 62) and Southwark Bridge (built 1815 ) in 1862. See COL, n 3, pp 131-2. For the removal of tolls on other London bridges, see Owen, n 14, pp 119-23, 243-4.

${ }^{146}$ Stubbs, n 3, p 511 'a penalty paid to the lord for impregnating his female villein.' OED, n 26 (childwite), 'a fine paid to the lord for getting one of his bondswomen with child.' See also Coke, n 12, vol 4, p 205; Riley, n 3 (Chronicles), p 109 and Norton, n 3, p 303. 
- Jeresgive (Yeresgive or Gieresgieve). This was a fine taken by the king's officers (mainly the sheriffs) on a person's entering into an office. ${ }^{149}$ Or, as Bohun points out, it was, rather, a sum of money (or bribe) given to them to connive at extortion or other offence in him who gave it; ${ }^{150}$

- Scotale. The meaning of this word is obscure. However, it likely signified a tax levied with reference to the sale of ale. ${ }^{151}$ Stubbs identified it as a form of forced contribution levied by unscrupulous officials, particularly sheriffs, ${ }^{152}$ and Bohun alleged it was a practice of the king's officers who kept alehouses (or who brewed liquors) which they forced men to come to their taverns and pay contributions (called scotales) for fear of displeasure..$^{153}$

Finally, citizens of London were granted the rights of infangthef and outfangthef, ${ }^{154}$ both now long obsolete.

- Infangthef was the right of a lord to seize (fangen being to seize) and try a thief, one of his own men, caught in his jurisdiction (manor) and to take the money payment - or penalty - imposed for the crime. Outfangthef was the right to do the same to a stranger caught in the lord's jurisdiction. The benefit of this right was the forfeiture of the thief's goods after his execution. ${ }^{155}$ A $1^{\text {st }}$ Charter of Edward III of 6 March 1327 provides for the citizens of London to have infangthef and outfangthef as well as the chattels of felons. ${ }^{156}$ These liberties were generally obsolete by the reign of Edward III (1327-77). ${ }^{157}$ In any case, forfeiture was abolished in 1870, the distinction between felonies and misdemeanours was abolished in 1967 and the death penalty no longer exists since $1998 .{ }^{158}$

In conclusion, murdrum, trial by battle, bridtol, childwite, jeresgive, scotale, infangthef and outfangthef are all long obsolete.

\footnotetext{
${ }^{147}$ Bohun, $\mathrm{n} 1, \mathrm{p} 34$. There were a number of variants in the spelling. Coke, n 12, vol 4, p 205 suggests that letherwite may have applied to fornication and adultery generally. See also, Riley, n 3 (Munimenta, Liber Custumarum, pt 2), pp 710, 738 and Luffman, n 3, p 12.

148 On villeinage, see $\mathrm{n} 27$. Jacob, $\mathrm{n} 3$, (in 1723) does not mention childwite.

${ }^{149}$ OED, n 26, 'Yeresgift (year's gift) 'A gift voluntarily given or exacted at the new year, or at the beginning of a year in office.' Stubbs, n 3 , p 516 'a payment made by burgesses to a royal oficial.' See also Riley, n 3 (Munimenta, Liber Custumarum, pt 2), p 777.

${ }^{150}$ Bohun, n 1, p 35. See also Riley, n 3, (Chronicles) p 109; Norton, n 3, pp 303-4 and Luffman, n 3, p 12.

${ }^{151}$ OED, n 26, 'An 'ale' or festival at which ale was drunk at the invitation of the lord of the manor of of a forester or other bailiff, for which ale a forced contribution was made.' See also Blount (1784), p 282 and Coke, n 12, vol 4, p 307. For charters referring to scotale, see Ballard, n 5 , pp 84-6.

${ }^{152}$ Stubbs, $\mathrm{n} 9$, vol 1, p 672 'The nature of this exaction is very obscure. It was however levied by the sheriff for his own emolument, probably as a reward for his services in maintaining the peace; and was raised by a process similar to that by which the guilds raised their common funds. Whether the sheriff could compel the burghers to make offerings of malt from which a 'scotale' was brewed, the proceeds of which went into his purse; or the name simply means a gathering of the burghers at which they were compelled to promise contributions to the same end, or at which heavy fines for non-attendance were inflicted, it is difficult to say.' See also Norton, n 3, pp 304-5.

${ }^{153}$ Ibid, p 37. See also Riley, n 3 (Chronicles), p 109 (probably compulsory payments for licence to brew or sell ale). See also Capitula Itineris (temp incert), Statutes of the Realm (1225-1713, 11 vols, pub 1828 under the authority of the Record Commissioners) ('SR'), vol 1, p 234 'Of inferior bailiffs which make the ale which is called scotale...that they may extort money from the suitors of the hundred and those subject to them.' See also Riley, n 3 (Munimenta, Liber Custumarum, pt 2), p 761 and Luffman, n 3, p 12.

${ }^{154}$ This is spelt a variety of ways including infangenthef, infangenthoef etc.

${ }^{155}$ Birch, $\mathrm{n} 3$, p xxv. 'the right to try a robber taken within the city, and the latter a privilege of bringing a citizen apprehended for a felony committed in any part of the kingdom into the city, in order to his being tried there for his offense.' Fleta, n 144, p 101. 'Infangthief, which means a thief, taken on someone's land, in seisin [possession] of stolen property, who is one of his own men. Outfangthief, which means a strange thief, coming thither from the land of another, who is arrested on the land of the possessor of these franchises.' Walker, n 27 (definitions of infangthef and outfangthef) 'Words used in grants of jurisdiction in early medieval law. The former is the right to hang a thief under one's own jurisdiction caught redhanded on one's land, the latter the right to do so whether or not the capture is made on one's own land.' Holdsworth (2009), vol 1, p 17 'Infangenetheof implied the right to try a thief taken on the property and at least a share in the profits (arising from the forfeiture of chattels after hanging). Also, vol 2, p 102 (he states that, until the middle of the $17^{\text {th }}$ century the Halifax Gibbet Law was a surviving instance of the franchise of infangthef). That Gibbet Law was last carried out in 1650, see Bateson, $\mathrm{n} 5, \mathrm{p}$ xxii and Blount, $\mathrm{n}$ 151, pp 323-7. See generally Bohun, n 1, p 36; Thomas, n 21, pp xi-xiii (who notes that most of the sokes of London appear to have had the right of infangthef, but they had disclaimed or resigned it) and O'Brien, $n$ 21, pp 74, 181-2.

156 'the said citizens may have infangthef and outfangthef, and chattels of felons of all those which shall be adjudged before them within the liberties of the same city, and of all being of the liberty aforesaid, at the aforesaid goal to be adjudged [ie. Newgate]'. See Birch, n 3, p 53.

${ }^{157}$ Norton, n 3, p 349 thinks they were obsolete even earlier. For cases of infangthef in 1337, 1339, 1341 and 1345 see Riley, n 3, (Memorials), pp 196, 206, 211, 221. See also Seyer (1812), p 46.

${ }^{158}$ See the Forfeiture Act 1870, the Criminal Law Act 1967, s 1 and the Crime and Disorder Act 1998, s 36.
} 


\section{Liberties - Taxes, Tallages and Aids}

Since the citizens of London were an easy target for sovereigns to raise money, it is not surprising they would seek to be free of such taxes as they could.

\subsection{Taxes - Scot and Lot and Danegeld}

A charter of Henry I (1100-35) of 1132 provides that the citizens:

shall be free from scot [eschot] and lot [hlote] and danegeld... ${ }^{159}$

As to these:

- Scot and Lot. 'Scot' was an Anglo-Saxon customary tax or contribution and 'lot' was a share (the reference to ' lot' does not appear in all versions of the charter of Henry I). ${ }^{160}$ Thus, reference to 'scot and lot' in the charter of Henry I likely refers to exemption from various taxes imposed by him and previous sovereigns. ${ }^{161}$ By the time of Edward II (1307-27), however, 'scot and lot' seems to have become linked to contributions to the up-keep of the City since the Constitutions of Edward II of 8 June 1319 required 'scot and lot' to be paid by freemen ${ }^{162}$ as well as non-resident freemen in respect of their goods. ${ }^{163}$ Thus, it seems to have become a form of municipal taxation which repealed - in effect the exemption contained in the charter of Henry I, since citizens (freemen) were no longer free of it. However it may have been interpreted in medieval times, an Act of 1725 provided that aldermen (and common councilmen) for the wards of the city of London were to be elected by freemen 'being householders, paying scot... and bearing lot, when required in their respective wards ${ }^{.}{ }^{164}$ The paying of 'scot' in this case was expressly linked to the payment of parish taxes - notably church rates, poor rates, payments to scavengers or for cleaning the City, payments to the London orphan's fund as well as other annual rates. ${ }^{165}$ And, bearing 'lot' was linked to performing civic services. ${ }^{166}$ By 1854, Pulling noted that municipal taxes levied by statute provided for the up-keep of the City. ${ }^{167}$ Therefore, by then - and certainly today - scot and lot no longer exists as a form of local municipal tax imposed by the City authorities but has long been replaced by statutory taxation;

\footnotetext{
${ }^{159}$ Birch, n 3, p 3.

${ }^{160}$ Bateson, $\mathrm{n} 5$, vol 2, p lxix 'the burgess's 'lot', or right to share was the proper accompaniment of the 'scot' or duty of payment to common charges.' Robertson, n 21, p 373 'The phrase scot and lot is generally used of the burdens shared in common by the members of the township'. See also Norton, n 3, pp 100-1, 281-3 (on the obscure nature of scot and lot).

${ }^{161}$ Robertson, n 21, p 289 interprets the reference to 'scot and lot' in the charter of Henry I to 'State taxes.' So too does Dowell (1888) vol 1, pp 11-2, 29-30. Gross (1967), vol 1, p 54 interpreted being in 'scot and lot' as meaning to 'participate in assessments or pecuniary charges.'

${ }^{162}$ 'That all and every one being in the liberty of the said city, and that would enjoy the liberties and free customs of the said city, be in lot and scot, and partake of all the burthens for maintaining the state of the said city, and the freedom thereof, according to the oath they have taken, when they were admitted into their freedom; and whose will not, to lose his freedom...' See Birch, n 3, p 47. Pulling, n 3, p 97 'being in scot and lot, or paying according to one's ability towards the common expenses.'

163 'And that all and every one, being of the freedom of the city, and living without the city, and that either by themselves, or by their servants, exercise their merchandises within the city, be in lot and scot with the commoners of the said city, for their merchandises, or else to be removed from their freedom.' This requirement to pay taxes also applied to 'common harbourers' in the city, see Birch, n 3, pp 47, 49.

${ }^{164} 11$ Geo 1 c 18 s 7 (1724) cited in Birch, n 3, p 283. See also Jacob, n 3, pp 77-9. Also, Sharpe, n 30, vol 3, pp 15-6 (the council of alderman determined that 'scot' comprised a reference to 'a general contribution of [to] all public taxes.')

${ }^{165} \mathrm{Ibid}, \mathrm{s} 8$. 'for the better ascertaining what are the rates and taxes, to which such householders ought to contribute and pay their scot, the same are hereby declared and enacted to be a rate to the church, to the poor, to the scavenger, to the orphans, and to the rates in lieu of or for the watch and ward, and to such other annual rates, as the citizens of London, inhabiting therein, shall hereafter be liable unto, other than and except annual aids granted or to be granted by parliament, and in case any such householder, within the space aforesaid, shall have been rated and charged, and contributed and paid his scot to all the said rates or taxes, or [30s] a year to all, or some of them, except as aforesaid; every such person shall be deemed and taken to be a person paying of scot.' See also Birch, n 3, pp 283-4. Jacob, n 3, p 140 'this scot and lot signifies a customary contribution laid upon all subjects, according to their ability. It is now attributed to all parish taxes, as such a one pays scot and lot to the church, poor, scavenger's rates etc. See stat[ute] 11 Geo 1[1725].'

${ }^{166} \mathrm{COL}, \mathrm{n} 3, \mathrm{p} 125$ 'Each householder was required to repair and sweep from his frontage to the kennel in the centre of the road...to hang out a light during the dark evenings, to provide a bucket of water at his door during the dry season, and to act in turn with the other householders as scavenger, beadle, and constable. The performance of such duties was called 'bearing lot.' The payment of rates in lieu of personal service, whereby permanent employees could be engaged, was termed 'paying scot."

${ }^{167}$ Pulling, n 3, p 97.
} 
- Danegeld. Originally, this was a form of land tax, an annual tax of 2 shillings imposed on every hide of land (about 120 acres) by Ethelred II (978-1016) in 991 in order to raise money for tribute demanded by the Danes. ${ }^{168}$ Later, danegeld became a tax for national defence which was levied from time to time. It was abolished in $1163 .{ }^{169}$

Thus, the charter of Henry I is obsolete in so far as it refers to 'scot and lot' and to 'danegeld.'

\subsection{Tallage and Aids}

After danegeld was abolished in 1163, it was replaced by 'tallage.' This was a tax on the royal demesne usually collected by the sovereign to raise money for military expeditions. Although the City was not (strictly) part of the royal demesne, ${ }^{170}$ it seems clear that it was tallaged from time to time. Its burden was probably especially heavy ${ }^{171}$ since the Constitutions of Edward II of 8 June 1319 provide:

That tallages or aids ${ }^{172}$ henceforth to be assessed for the king's business, or for the state and benefit of the City, after they shall be assessed by the men of the wards elected and deputed for this, be not increased nor heightened but by the common consent of the mayor and commonalty. ${ }^{173}$

Later, a $1^{\text {st }}$ charter of Edward III of 6 March 1327 provides:

We have also granted, for us and our heirs, that the same citizens, from henceforth, in and towards subsidies, grants and contributions whatsoever, ${ }^{174}$ to be made to the use of us or our heirs, shall be taxed and contributory with the commonalty of our realm, as common persons, and not as men of the City. And that they be quit of all other tallages. ${ }^{175}$

Thus, citizens of London were to be taxed no differently from other Englishmen. ${ }^{176}$ A $2^{\text {nd }}$ charter of James I of 20 September 1608 provides that non-freemen in the City are to be taxed equally with the citizens in all tallages, aids etc. ${ }^{177}$ The effect of all this was that - by 1608 - all persons living in the City paid the same Crown taxes as others. As it is, tallages and aids have long been obsolete. The last time tallage was levied (but not collected) was in 1334;

\footnotetext{
${ }^{168}$ Walker, $\mathrm{n} 27$ (danegeld) 'A tax of [2s] on every hide of land, originally imposed under Ethelred II of England in 991 to raise money for tribute exacted by the Danes, repeated several times later, and turned into a permanent levy for national defence by the Norman kings. It is usually applied to payments made between 991 and 1016. After 1162 it dropped out of use, but was revived as donum or hidage. The exaction was revived by Richard I [1189-99] under the name of carucage, a tax on all holders of land of whatever tenure.' See also Bohun, n 1, p 34; Stubbs, n 9, p 411 and Norton, n 3, p 283.

${ }^{169}$ Dowell, n 161, vol 1, pp 11-2, 29-30.

${ }^{170}$ Sharpe, $\mathrm{n} 30$, vol 1, p 2 '[The City] never formed a portion of the king's demesne (dominium), but has ever been held by its burgesses as tenants in capite by burbage (free socage) tenure.'

${ }^{171}$ See Letterbook D, n 3, p xxviii \& 305. See also Dowell, n 161, pp 41-3,60-7 and McKechnie, n 15, pp 231- 40.

172 Aids' were collected by the sovereign (and other lords) for: (a) knighting his eldest son; (b) marrying off his eldest daughter; (c) ransoming the sovereign. See Magna Carta 1225, ch 12. They were abolished by the Tenures Abolition Act 1660. See McBain (2010), p 541. Also, McKechnie, n 15, pp 231-40. For Anglo-Norman taxation see Stubbs, n 9, p 618 et seq.

${ }^{173}$ It continues 'And that the money coming from these tallages and aids be delivered into the custody of four honest men, commoners of the city, to be chosen by the commonalty, to be further delivered by the testimony of the said four men; so that they may inform the commonalty to what profit and for what uses, those moneys go.' See Birch, n 3, p 46.

${ }^{174}$ As well as tallage and aids, sovereigns collected tax using a variety of descriptions gifts, benevolences, loans, grants etc. See McBain, n 172, pp 535-48 and McKechnie, n 15, pp 234-40.

175 Birch, n 3, p 57.

${ }^{176}$ A 1 st charter of Edward IV of 9 November 1462 provides for all the inhabitants of the city to be liable to be assessed in all taxes. It states: 'all and singular merchants, as well denizens and aliens, abiding within the said city, and the liberties and suburbs of the same, and exercising merchandising or occupations there by any means, by themselves or others, though they be not of the liberty of the same city, shall be partakers, shall be taxed and contribute according to their faculties in subsidies, tallages, grants, and other contributions whatsoever by any means to be assessed for the need of us, or of our heirs, or of the said city, for the maintenance of the state, and profit of the same, with the citizens of the same city'. See Birch, n 3, pp 78-9. A derogation was made for merchants of Almaine (also called merchants of the Steelyard since their headquarters were in the Steelyard at Dowgate). See Pulling, n 3, p 383 and Norton, n 3, p 374.

177 'for the better and common profit of our city of London, and for the accommodation and support of the charges and expenses of the said city...all and singular persons, though they be not free of the same city, who now are, or hereafter shall be dwelling within the said city, the liberties or precincts of the same...in whatsoever aids, tallages, grants, and other contributions whatsoever to the use and service of us...or to the use of the said city, for maintaining the state, good or benefit of the said city, howsoever to be assessed, shall reasonably be taxed and contribute.' See Birch, n 3, p 145.
} 
and it was surrendered by Edward III in 1340 being superceded by parliamentary taxation. ${ }^{178}$ Aids were abolished by the Tenures Abolition Act $1660 .{ }^{179}$

In conclusion, the liberties of the citizens of London in respect of 'scot and lot', danegeld, tallage and aids are all obsolete.

\section{Liberty - To Elect a Mayor}

\subsection{Election of the Mayor}

The word 'mayor' 180 comes from the French 'maire' and, in London, the mayor likely replaced the Anglo-Saxon portreeve (or portgrave) who was the chief civil magistrate elected by the sovereign. ${ }^{181}$ The first mayor of London is said to have been Henry Fitz-ailwin appointed by the sovereign in 1189 (or 1192). ${ }^{182}$ Up to 1215, the mayor was likely elected by the sovereign. However, a charter of king John of 9 May 1215 provides that the citizens (the 'barons'):

may choose to themselves every year a mayor, who to us may be faithful, discreet, and fit for government of the city, so as, when he shall be chosen, to be presented unto us, or our justice[s] (if we shall not be present); and he shall swear to be faithful to us; and that it shall be lawful to them [ie. the citizens], at the end of the year, to amove him, and substitute another, if they will, or the same to retain, so as he be presented unto us, or our justice[s], if we shall not be present.... Wherefore we will and strictly command, that our aforesaid barons of our aforesaid city of London may choose unto themselves a mayor of themselves, in manner and form aforesaid. ${ }^{183}$

Similar wording is contained in a $2^{\text {nd }}$ Charter of Henry III of 18 February $1227 .{ }^{184}$ A $6^{\text {th }}$ Charter of Henry III of 12 June 1253 makes direct reference to the barons of the exchequer, who were the 'justices' referred to in the charter of king John. It states:

we have granted to the said citizens, that every mayor whom they shall choose in our city of London, (we being not at Westminster) they may yearly present to the barons of the exchequer, that he be admitted by them as mayor, so, notwithstanding, at the next coming of us or our heirs to Westminster or London, he be presented to us or our heirs, and so admitted mayor. ${ }^{185}$

Certain Constitutions for the regular Government of the City granted by Edward II on 8 June 1319 provide:

That the mayor ...be elected by the citizens of the said city, according to the tenor of the charters of our progenitors, heretofore kings of England, made to them thereby, and no otherwise. That the mayor remain only one year together in his mayoralty...That the mayor have no other office belonging to the city, but the office of mayoralty; nor draw to himself the sheriff's plea in the chamber of London, nor hold other pleas than those the mayor, according to ancient custom, ought to hold. ${ }^{186}$

Thus, in summary, these charters provide for the:

\footnotetext{
${ }^{178}$ McBain, n 172, p 537. See also Dowell, n 161, pp 60-7 and McKechnie, n 15, p 238.

${ }^{179}$ Ibid, p 541. As from 1688, the Bill of Rights 1688 (still extant) prevents the sovereign imposing taxes (whether tallage, aid, benevolence etc) without the consent of Parliament. Ibid, pp 536-48.

${ }^{180}$ As Halsbury, n 1, vol 29(2), para 44 notes, the 'title' of mayor dates from the 12th century and that of 'Lord Mayor' from the 13th; further, these titles evolved and were not bestowed by any prior commitment. See also Pulling, n 3, p 17. In this article, for the sake of brevity, the title 'mayor' is used.

${ }^{181}$ See Anon, n 3, p 34 and Pulling, n 3, p 18. Sharpe, n 30, vol 1, p 65 'The head of the city was no longer a Saxon 'port-reeve' but a French 'mayor', the former officer continuing in all probablility to perform the duties of a port-reeve or sheriff of a town in modified form.' See also OED, n 26 (mayor) 'The head or chief officer of the municipal corporation of a city or borough.'

${ }^{182}$ See Bohun, n 1, p 40 et seq. Whether mayors were elected prior to 1215 is unclear. See also COL, n 3, p 16.

${ }^{183}$ Birch, n 3, p 19. See also Stubbs, n 9, p 382 and Norton, n 3, pp 315-7. Also, Ballard, n 5, p lxxxvii.

184 'they may choose to themselves a mayor of themselves, every year, who may be to us faithful, discreet, and fit for the government of the city, so as, when he is chosen, he may be presented unto us, or our justices, if we be not present, and shall swear to be faithful to us: And that it shall be lawful for them in the end of the year to amove him, and to substitute, or, if they will, to retain him still, so as always that he be presented to us, or to our justices, if we be not present.' See Birch, n 3, p 24.

${ }^{185}$ See Birch, n 3, pp 34-5 \& p xviii. A charter of Edward I of 28 May 1298 provides for the mayor to be presented to the constable of the Tower if the sovereign or his barons of the exchequer were not present in London, viz the mayor 'may or shall be presented or admitted to and by the constable of our Tower of London yearly, in such sort as before they were wont to be presented and admitted; so as nevertheless, that, at the next coming of us or our heirs to Westminster or London, the said mayor be presented to us or our heirs, and admitted for mayor.' See Birch, n 3, pp 43 \& xxi-ii. Also, Pulling, n 3, p 17.

${ }^{186}$ See Birch, n 3, pp 45-6.
} 
- citizens to elect a mayor 'faithful, discreet and fit for government of the city' (since 1215);

- the mayor is to be presented to: the sovereign or (if absent) the barons of exchequer or (if absent) to the constable of the Tower of London (since 1215);

- the mayor will swear to be faithful to the sovereign (since 1215);

- the mayor is subject to annual election (since 1319);

- the mayor is to hold no other office belonging to the City (since 1319);

- the mayor is not to draw to himself the sheriff's pleas in the chamber of London nor hold pleas other than as mayor (since 1319).

A number of these provisions have altered over time:

- Today, the mayor is not elected by the citizens of London; he is elected by the liverymen. ${ }^{187}$ Nor he is ' $f$ it for government of the city' meaning the entire city of London, rather, his 'fitness' relates only to the Square Mile. Royal approval is no longer given directly but by the Lord Chancellor; ${ }^{188}$

- The barons of the exchequer no longer exist. ${ }^{189}$ Thus, the presentation, and swearing, of the mayor - as laid down in the City of London (Various Powers) Act 1959, s 5 - takes place in the Queen's bench division of the High Court or before the judges of that division; ${ }^{190}$

- Despite the injunction in the Constitutions of 1319, the mayor has acquired many offices (see 8.2 below);

- Finally, the mayor no longer sits in the sheriffs' court, or court of Hustings, since they no longer operate (see 4).

Given this, the terms of the charters have been effectively superceded by legislation and it would be more appropriate for legislation to now clarify the matter. That, is for the City of London (Various Powers) Act 1959, s 5 to be replaced by wording which provides for the mayor:

- to be elected annually by the liverymen;

- to give an oath to the sovereign in the presence of the court of Queen's bench.

Since the mayor's also being presented to the Lord Chancellor was a later innovation - and since it duplicates the ancient presentation to the barons of the exchequer (now judges of the Queen's bench) representing the sovereign - this presentation to the Lord Chancellor would seem unnecessary (it is also wholly formal). Consideration, therefore, should be given to reversion to the older form (ie. presentation before the Queen's bench only) .

In conclusion, since the wording in the charters of London relating to the election of the mayor is almost wholly obsolete it should now be contained in modern legislation - recognising the current position.

\subsection{Offices of the Mayor}

The mayor - as mayor - had certain offices assigned to him by the London charters viz.

- Justice of Oyer and Terminer and JP's. A $1^{\text {st }}$ Charter of Edward III of 6 March 1327 provides for the mayor to be one of the judges assigned to the goal delivery of Newgate prison. ${ }^{191}$ A $1^{\text {st }}$ charter of Edward III of 9 November 1462 provides for the mayor and the recorder (as well aldermen who have been past mayors) to be Justices of the Peace (JP's) and justices of oyer and terminer. ${ }^{192}$ So does a $2^{\text {nd }}$ charter of

\footnotetext{
${ }^{187}$ Halsbury, n 1, vol 29(2), para 44 'The election of the Lord Mayor of London takes place in Guildhall on Michaelmas day in each year, unless that day falls on a Saturday or Sunday, in which case the election is held on the following Monday. The liverymen of the City of London in Common Hall assembled choose, from among the aldermen who have filled the office of sheriff, two candidates, and of these the Court of Aldermen appoints one to the office of Lord Mayor for the next ensuing year. Royal approval to the appointment is received from the Lord Chancelllor, usually early in October.' The election of the mayor by the liverymen was established in 1724 (11 Geo I c 18), there having been much confusion prior to this. See RC, n 14, vol 18, p 364.

${ }^{188}$ Ibid. 'Royal approval to the appointment is received from the Lord Chancellor.' As Norton notes, n 3, p 317 (in 1869) this was a new practice not provided for in a charter. This practice was occuring before 1732 since it is referred to in Jacob, n 3, p 107. CMC, n 14, p 30 'the act of the chancellor... since the reign of Edw III [1327-77], at least, has been merely formal.'

${ }^{189}$ See $\mathrm{n} 83$.

${ }^{190}$ City of London (Various Powers) Act 1959 s 5(1) 'The presentation and swearing of the lord mayor shall take place in the Queen's bench división of the High Court or before the judges of that division on the second Saturday in November in every year and in the same manner as was formerly accustomed in the Court of Exchequer.' See also Halsbury, n 1, vol 29(2), para 44; RC, n 14, vol 18, p 367 and COL, n 3, pp 16-7. 191 'the mayor...shall be one of the justices assigned of the goal delivery of Newgate, and to be named in every commission thereof.' See Birch, n 3, p 53. See also Pulling, n 3, pp 22-3 and Norton, n 3, p 360-1.

${ }^{192}$ See Birch, n 3, pp 74-6. Also, Pulling, n 3, pp 208-17. A charter of Henry VIII of 16 June 1518 provides that 'all inquisitions from henceforth to be taken by the justices, and other the ministers of the men of the said city, should be taken at Great St Martin's in London, and not
} 
James I of 20 September $1608^{193}$ as well as a $1^{\text {st }}$ charter of Charles I of 18 October $1638 .{ }^{194}$ The latter also provides for the mayor to name a JP for Middlesex and one for Surrey. ${ }^{195}$ Finally, a charter of George II of 25 August 1741 constitutes all aldermen of the City (including the mayor) to be JP's. ${ }^{196}$ This last charter of 1741 superceded previous charters as to the mayor and aldermen being JP's. ${ }^{197}$ Today, justices of goal delivery and oyer and terminer no longer exist. ${ }^{198}$ Nor does Newgate prison. ${ }^{199}$ Further, the mayor and aldermen no longer sit as JPs for the City ${ }^{200}$ and it is most unlikely they would be appointed as such by the Lord Chancellor in modern times. ${ }^{201}$ Although, by custom, the Lord Mayor is declared to be the chief magistrate of the city, ${ }^{202}$ this title is obsolete since the lord mayor does not now sit as a magistrate. The mayor is also entitled (as are the aldermen and sheriffs) to sit as a judge of the Central Criminal Court with any judge of the high court (or any circuit judge, recorder or district judge) ${ }^{203}$ However, the mayor does not presently sit qua judge ${ }^{204}$ and it would not seem appropriate for him to continue to sit with the other judges in modern times; ${ }^{205}$

- Escheator of the City A $1^{\text {st }}$ Charter of Edward III of 6 March 1327 provides for the mayor to be perpetual escheator of the City and Southwark. ${ }^{206}$ Land reverted (escheated) to the lord if the tenant died without heirs or if he committed a gross breach of the feudal bond, such as by committing treason or felony. In London, the escheator looked after the lands or profits that reverted to the sovereign in this fashion. ${ }^{207}$ Escheat on death was abolished in 1925 and escheat for breach of the feudal bond having been abolished in $1870 .{ }^{208}$ Thus, this title is obsolete; ${ }^{209}$

elsewhere, except inquisitions to be taken in circuits in the Tower of London, and for the goal delivery of Newgate.' See Birch, n 3, p 97. Both inquisitions, and the courts of St Martin-le-Grand and of the Tower, are obsolete. See 4.

${ }^{193}$ See Birch, n 3, pp 146-9 (the sheriffs to assist them in that office).

194 Ibid, pp 169-71.

195 Ibid, pp 187-8.

${ }^{196}$ Ibid, p 293 'mayor, recorder, and all the aldermen of the said city of London...be... a justice and justices of the peace.' See also a charter of William and Mary of 28 July 1692 (see Appendix, no 44). Also. Norton, n 3, p 407.

${ }^{197}$ Noted in COL, n 3, p 60.

198 Justices of eyre (itinerant justices sent on circuit every 7 years) became redundant in the 14th century. Justices of assize (including those assigned to goal delivery) and justice of 'oyer and terminer' (ie. those appointed in special cases, the commission given to them being to hear, and determine, the offences specified) no longer exist, the assise system being abolished in 1971. See Courts Act 1971, s 1(2) and Baker, 52, pp 17,22 .

${ }^{199}$ Newgate was a prison built (or enlarged) in 1188, situated at the corner of Newgate Street and the Old Bailey, just inside the City of London. It was demolished in 1904 and the Central Criminal Court (the new Old Bailey) now stands on the site. See generally, Pugh (1968) and Stow, n $3, \mathrm{p} 34$.

${ }^{200}$ Halsbury, n 1, vol 29(2), para 45 'the Lord Mayor and Aldermen of the City of London may not now be [JPs] unless appointed by the Lord Chancellor in accordance with the Justices of the Peace Act 1997.' See now Access to Justice Act 1999, s 76(1).

${ }^{201}$ The mayor and alderman hold, in effect, quasi-political positions. Thus, any suggestion of bias, or political interference, should be avoided.The mayor and aldermen are also very busy on matters concerned with the Corporation of London.

${ }^{202}$ This title does not appear to derive from any charter. RC, n 14, vol 18, p 25 suggests it derives from the 4th charter of Edward III in 1354 (see Appendix, no 27). This seems incorrect. This title was preserved by the Justice of the Peace Act 1968 s 1(2) and the Justices of the Peace Act 1997 s 23 (repealed). See Halsbury, n 1, vol 29(2), para 46. Also, RC, n 14, vol 17, p 74.

${ }^{203}$ Halsbury, n 1, vol 29(2), para 46 and Supreme Court Act 1981, s 8(3). Pulling, n 3, p 210 (in 1854) 'He attends at the opening of the sessions at the Old Bailey, and is supposed to be always present there, his sword remaining in court, and his seat being supposed to be unoccupied except by himself during the sessions.'

${ }^{204}$ COL, n 3, p 73 (in 1953) 'The mayor takes no part in the legal proceedings.'

205 See $n 201$.

206 'no, escheator, or other officers, may, from henceforth, exercise the office of escheator within the liberties of the said city: but that the mayor of the said city for the time being may do the office of escheator within the said liberty; so as always he take his oath that he exercise the said office, and that he answer thereof to us and our heirs, as he ought to do.' See Birch, n 3, p 55; Pulling, n 3, p 19 and Halsbury, n 1, vol 29(2), para 46. See also Chew (1943), pp 319-30 and RC, n 14, vol 18, p 367.

${ }^{207}$ See Coke, n 12, vol 4, p 225. Blackstone, n 2, p 244 'escheat...denotes an obstruction of the course of descent, and a consequent determination of the tenure, by some unforeseen contingency: in which case the land naturally reverts back, by a kind of reversion, to the original grantor or lord of the fee.' In the City, there was no escheat except to the sovereign, see Bateson, n 5, vol 2, p 161.

${ }^{208}$ Walker, n 27 (escheat). See also COL, n 3, p 20 and Norton, n 3, pp 356-7.

${ }^{209}$ Pulling, n 3, p 19 (in 1854) noted 'No escheat has fallen in London or Southwark for many years.' RC, n 18, vol 2, p 367 'The Commissioners of 1837 reported that no escheat had fallen in the City for 30 years.' See also CMC, n 14, p 77. 
- Bailiff of the Thames. A charter of Richard I of 14 July 1197 orders all weirs in the Thames to be removed. ${ }^{210}$ A $1^{\text {st }}$ charter of James of 20 August 1605 grants to the mayor the office of bailiff and conservator of the Thames up to Staines bridge (westward) and Kendal (eastward) and in the Medway and the Port of London (including wharfs), with the fees and profits there belonging. ${ }^{211}$ These charters no longer apply since the jurisdiction which the City enjoyed as conservators of the Thames passed to the Thames Conservancy in $1857 .{ }^{212}$ Since 1996, the Thames has been under the jurisdiction of the Environment Agency. ${ }^{213}$ Thus, this title is obsolete;

- Admiral of the Port of London. The mayor was declared to be an admiral of the port of London although this office or appointment did not arise by virtue of any charter. ${ }^{214}$ This claim, as Pulling noted in 1854 , is dubious in nature and, as noted in 1837 , no courts of admiralty were held under the authority of the Corporation of London. ${ }^{215}$ Today, although the mayor is still declared to be an admiral of the Port of London, he has no legal jurisdiction, or role, there. ${ }^{216}$ Thus, this title is obsolete;

- Clerk of the Market. A $1^{\text {st }}$ charter of Edward III of 6 March 1327 excludes the royal clerk of the market from exercising his office in the City. ${ }^{217}$ The effect was to make the mayor clerk of the City markets to the exclusion of the Crown appointed clerk. ${ }^{218}$ The purpose of the clerk was to check weights and measures and fine those whose weights and measures were defective. ${ }^{219}$ However, when Blackstone wrote in

210 'all wears that are in the Thames be removed, wheresoever they shall be within the Thames: Also we have quitclaimed all that which the keeper of our Tower of London was wont yearly to receive of the said wears.' See Birch, n 3, pp 9-10. See also: (a) 2nd charter of John of 17 June 1199 ('all the wears which are in the Thames or in the Medway be amoved; wheresoever they shall be within the Thames and Medway; and that no wears from henceforth be put any where in the Thames or Medway, upon forfeiture of [£10].' See Birch, n 3, p 13; (b) $3^{\text {rd }}$ charter of Henry III of 18 February 1227 ('all the wears which are in the Thames or in the Medway shall be amoved; and that no wears from henceforth be put anywhere in the Thames, or the Medway, upon forfeiture of [£10].' See Birch, n 3, p 26; (c) $1^{\text {st }}$ charter of Edward III of 6 March 1327 ('the said citizens may remove and take away all the wears in the waters of Thames and Medway, and may have the punishments thereof to us belonging.'). See Birch, n 3, pp 54 \& xiv. See also Magna Carta (1215), ch 33 (removal of all fish weirs from the Thames); McKechnie, n 15, pp 343-6 and Norton, n 3, pp 305-6.

211 'the said office of bailiff and conservation of the water of Thames.' See Birch, n 3, p 135. See also Bohun, n 1, p 50 and Pulling, n 3 , p 125 et seq. The Constitutions for the regular Government of the City granted by Edward III of 8 June 1319 also made provision in respect of the old London Bridge (demolished in 1832), 'That the keeping the bridge of the said city, and the rents and profits belonging to that bridge, be committed to be kept to two honest and sufficient men of the city, other than the aldermen, to be chosen to this by the commonalty, at the will of the said commonalty, and not to others; and who may answer thereupon to the said commonalty. See Birch, $\mathrm{n} 3$, p 49. This wording is obsolete, tolls being abolished on the bridge in 1767, see $\mathrm{n} 145$.

${ }^{212}$ See $\mathrm{n}$ 112. For the Act of 1393 giving the Mayor of London authority to 'conserve the Thames' see McKechnie, $\mathrm{n} 15, \mathrm{p} 343, \mathrm{n} 2$.

${ }^{213}$ Halsbury, n 1, vol 29(2), para 46, 'He is, by custom...Admiral of the Port of London.' See also vol 49(2), para 771.

${ }^{214}$ Pulling, n 3, p 21 'The lord mayor is admiral of the port of London, but no courts of admiralty are now held under the authority of the corporation. Nor has any one of the privileges attached to this function been exercised by the lord mayor in person, since the reign of Elizabeth [1558-1603], with the exception of a claim to royal fish caught in the river, occasionally enforced on behalf of the lord mayor.' The reference to royal fish is incorrect. The claim to royal fish derived not from the mayor being an admiral but from his being bailiff and conservator of the Thames, a post now obsolete. In any case, royal fish, being a European protected species, cannot now be claimed. See McBain, $\mathrm{n} 172$, pp 548-51 and RC, n 14, vol 18, p 367 ('no privileges of the office [of admiral] have been exercised since the reign of Elizabeth I ).' See also Pulling, n 3, pp 323-4 and Halsbury, n 1, vol 29(2), para 46.

${ }^{215}$ Pulling, n 3, p 323 'it may...safely be inferred that the lord mayor has no powers, as admiral, within the port of London, any more than the high court of admiralty have in other rivers.' See also COL, n 3, p 21 and CMC, n 14, p 78.

${ }^{216}$ The mayor is not an admiral employed by the Ministry of Defence. Nor is the Port of London part of the City and, were the mayor to actually try and assert authority, qua admiral (to direct ships etc), he would (justifiably) be ignored. Glasspool (1924), pp 3-4, 'By compliment the Lord Mayor is an admiral of the port of London, though I have never seen his lordship wearing the uniform of an admiral carry out this duty. He is quite content with the compliment.'

217 'we will and grant...that the marshal, steward or clerk of the market of our household, may not sit from henceforth within the liberty of the... city, nor exercise any office there' See Birch, n 3, p 55. See also 27 Hen VIII (1536) c 24 s 12 . For the grant of clerk of the market in Southwark, see Appendix, n 30 (1462). See generally, Eboranos (1737).

${ }^{218}$ Pulling, n 3, pp 19-20. When the City acquired the office of clerk of the markets is uncertain. Norton, n 3, p 377 thought it was in the reign of Edward II (1307-27). See also O'Keefe (1978), vol 1, para 248 and Pease (1899), pp 10-3.

${ }^{219}$ Blackstone, n 2, vol 4, p 272 'The court of the clerk of the market is incident to every fair and market in the kingdom, to punish misdemeanours therein... The object of this jurisdiction is principally the cognizance of weights and measures, to try whether they be according to the true standard thereof, or no...If they be not...besides the punishment of the party by fine, the weights and measures themselves ought to be burnt.' 
1766 about clerks of the market they were almost obsolete (because justices of the peace, sheriff's tourns and court leets all had the power to inquire into false weights and measures) and, in 1854, Pulling noted that this office in the City was actually performed by the committee of City lands. ${ }^{220}$ The Markets and Fairs Clauses Act 1847 required the owners of markets to provide proper weights and measures for commodities sold at fairs, obviating the clerk's job. ${ }^{221}$ Thus, the office of clerk of the market is obsolete. ${ }^{222}$ Courts of clerks of the market no longer operate after $1977 ;^{223}$

- Keeper of the Great Beam. From early times in the City there was a great beam (also called the king's beam or tron) for weighing wool and other coarse goods by the hundredweight. ${ }^{224}$ The office of keeper together with the right to charge for its use (called tronage) ${ }^{225}$ - was often farmed out by the mayor, the person selected often being at the request of the sovereign. ${ }^{226}$ In the time of Henry VIII (1509-47) the office of keeper was farmed out - by patent - to Sir William Sidney in 1521. However, a charter of Henry VIII of 13 April 1531 restores the office of keeper of the great beam to the mayor, commonalty and citizens of London ${ }^{227}$ and a $1^{\text {st }}$ charter of Charles I of 18 October 1638 confirms the grant to the mayor the right to be the keeper of the great beam, together with all fees. ${ }^{228}$ The great beam (as well as the common beam and small beam) no longer exists. ${ }^{229}$ Pulling (in 1854) noted that - when the system of selling by wholesale out of the markets came to be established - this system of public weighing came into disuse, although he noted that a weigh house had existed 'until a comparatively recent period' but was 'now abolished.' ${ }^{230}$ Thus, the office of keeper of the great beam is obsolete, ${ }^{231}$

- Guager/Measurer of Merchandise. A $4^{\text {th }}$ charter of Edward III of 20 June 1478 grants to the mayor and commonalty the offices of: (a) package, ${ }^{232}$ (b) scavage (also called shewage, searching or surveying), ${ }^{233}$

\footnotetext{
${ }^{220}$ See Pease, n 218, pp 12-3 and Pulling, n 3, p 20. The latter was also noted in 1837, see CMC, n 14, p 78.

${ }^{221}$ Ibid, p 156. Pulling notes that the clerk of the market (an officer of the king's household) had a general responsibility to check weights and measures until 5 Geo IV c 74, s 23 (1824, rep). See also Norton, n 3, p 356 and Seyer, n 157, p 94.

${ }^{222}$ Ibid, p 13, 'It has been stated recently that one of the latest recorded instances of a clerk of the market exercising powers as a king's officer was in Middlesex, in 1738, when such an officer was authorised by letters patent to inspect all weights and measures within the "little virge." The office of clerk of the market never seems to have been abolished, however. At Oxford there are still two clerks of the market although these are (academic) ceremonial positions. The Weights and Measures Acts 1878-1897 provided for the use of the same weights and measures throughout the UK and for county and borough councils to appoint inspectors of weights and measures. See also Pease, n 218, pp 98-100.

${ }^{223}$ Administration of Justice Act 1977, s 23 and Sch 4, pt 1.

${ }^{224}$ The king's beam was located in the churchyard of St Mary in Walbrook. There was also a small beam (balance) for weighing silks and spices by the pound weight. See Letterbook D, n 3, p xvii. Like the position in respect of the great beam, the office of keeper of the small beam was often farmed out, see eg. Sharpe, n 30, vol 1, pp 124 \& 133. See generally Kingdon (1901). For a reference to the farm of the great beam in 1189 see Petit-Dutaillis, n 9, p 106.

${ }^{225}$ Bohun, n 1, p 37 'Tronage is a duty paid at the city beam for weighing lead, wax, pepper, allom etc.' An Act of 11 Hen 6 c 8 (1433, rep) charged the mayor of London to keep and execute the statutes on weights and measures. The office of tronour (tronator) was set out in 17 Ric 2 c 5 (1393).

${ }^{226}$ Letterbook D, n 3, pp xvii \& p 297.

${ }^{227}$ See Birch, n 3, pp 99-105 \& xxxiv. See also Jacob, n 3, p 21; Gomme, n 3, p 381; Sharpe, n 30, pp 387-8 and Norton, n 3, pp 385-6.

228 'the office of keeper of the great balance or weight within the said city.' See Birch, n 3, p 183.

${ }^{229}$ An Act of 8 Hen VI c 5 (1429, rep) required a common balance to be kept in every town. See Pulling, n 3, pp 391-2 and Norton, n 3, pp 376-8.

${ }^{230}$ Pulling, n 3, pp 391-2. See also O'Keefe, n 218, vol 1, para 263.

${ }^{231} \mathrm{COL}, \mathrm{n} 3, \mathrm{p} 119$ (in 1953) 'In past centuries considerable sums were received from tolls and fees connected with trade, for measuring, weighing, and sorting, for package, baillage, and scavage, and for numerous other checks and duties performed by the Corporation through officers known by such name as meters and guagers...all these remunerative functions have been abolished, purchased by the Crown, or incorporated into the duties of modern statutory inspectors.' In respect of weighing and measuring, the authority in the metropolitan area was transferred to the London County Council in 1885 and the mayor and aldermen were no longer involved.' Ibid, p 176.

232 'packing of all manner of woollen cloths, sheep skins, calves-skins, goat skins, vessels of amber, and of all other merchandises whatsoever, to be packed, tunned, piped, barrelled, or anywise to be inclosed, with the oversight of opening all manner of customable merchandises arriving at the port of safety, as well by land as by water, within the liberties and franchises of the said city and suburbs of the same etc.' See Birch, n 3 , p 91 \& xxxii. Also, Norton, n 3, p 379.

${ }^{233}$ Basically, scavage was the inspecting of goods of foreigners on which import customs were to be paid. See Norton, n 3, p 380. OED, n 26 'A toll formerly levied by the mayor, sheriff, or corporation of London and other towns on merchant strangers, on goods offered for sale within their precincts.' It was abolished by 19 Hen VII c 8 (1503-4), with a saving for London. See also 24 Geo III sess 2 c 16 (1784). See also Norton,
} 
(c) portage (also called carriage or cartage); ${ }^{234}$ (c) garbling; ${ }^{235}$ (d) guaging (including wines); ${ }^{236}$ and (e) wine drawing. ${ }^{237}$ The offices of garbling and guaging are confirmed in a 2 nd charter of Charles I of 18 October $1638^{238}$ and the offices of package, portage, scavage and water bailliage are confirmed in a $2^{\text {nd }}$ charter of Charles 1 of 5 September $1640 .{ }^{239}$ A $1^{\text {st }}$ charter of James of 20 August 1605 grants to the mayor the office of measurer of all coals, grain and other merchandise ${ }^{240}$ and a $2^{\text {nd }}$ charter of 20 September 1608 confirms the scavage of oil and other things brought to the port of the City as well as the metage of coal, corn etc. ${ }^{241} \mathrm{~A} 3^{\text {rd }}$ charter of James I of 15 September 1614 grants and confirms to the City the measuring and weighing of all coals in the port of London from Yenleet to Staines Bridge. ${ }^{242}$ All of these offices were intimately connected with the carrying of goods from the port of London, as well as the imposition of fees (port customs) on foreign importers and, in the case of water baillage, exporters. In 1833 , the Treasury paid the City the sum of $£ 160,000$ to abolish the duties of package, scavage, baillage and portage. ${ }^{243}$ Coal and wine duties were abolished in 1889 and the metage of grain in 1902. ${ }^{244}$ As for the office of guager, on the building of the London docks, there was dispute whether they could be gauged by the City. ${ }^{245}$ An Act of 1817 compensated for the loss of this right and others in respect of the London docks. ${ }^{246}$ The office of gauging was preserved by the Weights and Measures Act 1824, s 25 (still extant). It provides that all tuns of wine, oil, honey and other liquors imported into the port of London are liable to be gauged by the mayor (or his deputy). ${ }^{247}$ This section has long been obsolete as has the office of the mayor as guager. Thus, section 25 should be abolished, as should the office of guager; ${ }^{248}$

n 3, p 382; Riley, n 3 (Chronicles), p 22; COL, n 3, p 140; Riley, n 3 (Munimenta, Liber Albus III), p 64; Selden Society Reports, vol 25, pp 120-1 (Browne v Busshell (1517)), $\mathrm{n} 8$ and vol 16, pp 71-7 (Hewyt et al $v$ Mayor of London etc (1500)).

234 'office of carriage and portage of all wools, sheep-skins, tynn-bails, and other merchandises whatsoever, which shall be carried into London from the water of Thames unto the houses of strangers, and contrarywise from the same houses to the said water, or of other merchandises which ought to be carried, being in any house for a time.' See Birch, n 3, p 91.

235 'office of occupation of garbling of all manner of spices, and other merchandises coming to the said city at any time, which ought to be garbled.' See Birch, n 3, p 91. Garbling was the sorting of goods in terms of quality. See also Coke, n 12, vol 4, pp 263-5.

236 'office of guager within the said city.' See Birch, n 3, p 91. This office was confirmed in letters patent of Henry VII issued on 23 July 1485 and referred to in Regulations of 22 August 1585 cited by Birch, n 3, p 94 (see Appendix, no 34). See also Norton, n 3, p 384.

237 'the office of wine-drawers, to provide for the carrying of wines brought to the port of the said city, and laid on land wheresoever it be, and elsewhere to be carried.' See Birch, n 3, p 91.

${ }^{238}$ Ibid, n 3, pp 180-2.

${ }^{239}$ Ibid, p 201 et seq. See also Norton, n 3, pp 404-6 (water baillage comprised scavage for exported goods).

240 'measurer of all and singular coals, and grain of what sort soever, and all kinds of apples, pears, plums, and other fruit whatsoever, and all roots to be eaten of what sort soever: And also of onions, and other merchandises, wares and things measurable, and the measuring of them, whatsoever, in or to the port of the city of London, coming, carried, or brought, in whatsoever ship, boat, barge, or other vessel, floating, laden, remaining or being in any part of the same river of Thames, and upon any bank, or shore, or wharf of the same water of Thames.' See Birch, $n$ 3, pp 135-6 \& xxxvi; Pulling, n 3, p 20 and Norton, n 3, p 392.

${ }^{241}$ See Birch, n 3, p 142 and Norton, n 3, p 396.

${ }^{242}$ Ibid, pp 152-8.

${ }^{243}$ Duties of Packing etc London Act 1833. See also Allen, n 3, p 48

${ }^{244} \mathrm{RC}, \mathrm{n}$ 14, vol 18, p 379 and COL, n 3, pp 150, 176. It had already been commuted to a fixed rate in 1872, see Owen, n 14, p 228.

${ }^{245}$ The Mayor of London etc of London v Long (1807) 1 Campbell's Reports 22 (170 ER 862). See also 170 ER 920-1 (1808) and the Annual Register 1809, p 283.

24657 Geo III c 60 (1817).

247 'all tuns, Provided always...that...all tuns, pipes, tertians, hogsheads, or other vessels of wine, oil, honey, and other guageable liquors, imported or brought into the port of the city of London, and landed within the said city and the liberties thereof, shall be subject and liable to be gauged, as heretofore have been of right accustomed, by the lord mayor of the said city for the time being, by virtue of his office of gauger, or by his sufficient deputies, lawfully appointed, ... and that all such tuns, pipes, tertians, hogsheads, or other vessels that shall be found wanting of the true contents which such tuns, pipes, tertians, hogsheads, or other vessels ought to be of, to be ascertained as aforesaid, together with the wine and other liquids therein contained, shall be subject and liable to the like seizures and forfeitures as is or are provided by any Act or Acts of Parliament heretofore made for ascertaining the true contents of tuns, pipes, tertians, hogsheads, and other vessels of wine, oil, honey, and other guageable liquors; and that the moieties of such forfeitures due to his majesty, shall be, in like manner as heretofore hath been accustomed, accounted for by the lord mayor for the time being, as such gauger, and his deputies, to his majesty, in his court of exchequer at Westminster.' This section was preserved by Weights and Measures Act 1985, s 90(1). Entitled 'Saving for certain rights in City of London' it provides that '...nothing in this Act shall affect any rights of the mayor and commonality and citizens of the City of London or of the Lord Mayor of the City of London for the time being with respect to the stamping or sealing of weights and measures, or 
- Outroper. A $1^{\text {st }}$ charter of Charles I of 18 October 1638 grants to the mayor the office of outroper (or common crier) in London and Southwark and to exercise the same by means of a deputy. ${ }^{249}$ It should be noted that the outroper is not the same as the modern common crier (including the City's common cryer and sargeant-at-arms). The outroper sold goods by open claim and outcry ${ }^{250}$ and no one else was permitted to sell any other goods by outcry in the City. The office of outroper is now obsolete;

- Coroner of the City. A $4^{\text {th }}$ charter of Edward III of 20 June 1478 grants to the mayor the office of coroner. ${ }^{251}$ The mayor also became coroner in Southwark. ${ }^{252}$ The mayor is no longer able to be a coroner and this title, anyway, is said to be unfounded. ${ }^{253}$ Thus, this title is obsolete;

- Registrar of Pawns. A $1^{\text {st }}$ charter of Charles I of 18 October 1638 establishes a register of pawns and for the mayor, commonalty and citizens to execute the office of broker of pawns etc. ${ }^{254}$ This register no longer exists, as noted by Norton in $1869 .{ }^{255}$ Thus, this office is obsolete;

- Custody of Bedlam. A $1^{\text {st }}$ charter of Charles I of 18 October 1638 confirms the grant of the custody of the mental asylum of Bedlam (ie. St Mary of Bethlem without Bishopsgate which was located within the City and founded in 1246) to the mayor. ${ }^{256}$ Bedlam still exists. However (as the Bethlem Royal Hospital) it is now located in Bromley and is part of the South London and Maudsley NHS. ${ }^{257}$ Thus, the mayor no longer controls Bedlam;

- Butler. From long standing custom, the mayor acted as an assistant to the chief butler at the coronation banquet of the sovereign for which he received a gold tankard or cup for his fee. ${ }^{258}$ This office is in abeyance since such banquets have not been held since 1821 and are very unlikely to be held again. ${ }^{259}$

with respect to the gauging of wine or oil or other gaugeable liquors.' The Common Council of London is a local weights and measures authority under the Weights and Measures Act 1985, s 69(1)(b).

${ }^{248} \mathrm{RC}, \mathrm{n} 14$, vol 18, p 379 'the [Corporation's] rights of guaging guageable articles have never been taken away; but as far as wine is concerned they have practically been lost, because nearly all the wine that comes into the port of London goes to the docks, which are not under the control of the Corporation. The Corporation attempted to assert the right to act as guagers in the docks, but it was determined in 1817 that the right of guaging did not extend to the site of the docks.' COL, n 3, p 176 (in 1953) 'With the passage of centuries and the development of new methods of trade, the exercise by the corporation of the right to guage, meter, measure, and weigh fell into disuse or was made redundant by statutes.' The mayor may also have been concerned in the assize of bread and other victuals and liquors in the City and Southwark (although this was often handled by way of proclamation. The assize of bread etc was abolished in 1836. See Pulling, n 3, p 20.

${ }^{249}$ See Birch, n 3, pp 184-5.

250 'outroper, or common crier, to and for the selling of household stuff, apparel, leases of houses, jewels, goods, chattels, and other things of all persons who shall be willing that the said officers shall make sale of the same things by public and open claim, commonly called outcry.' See Birch, n 3, pp 184-5. Norton, n 3, p 401(in 1869) 'the legality of this exclusive grant by charter of such an office may be reasonably doubted.'

251 'mayor...may have full power and authority to exercise and do all and singular things, which to the office of coroner within the said city, and suburbs of the same, do pertain to be exercised and done.' See Birch, n 3, p 92.

${ }^{252} \mathrm{COL}, \mathrm{n} 3, \mathrm{p} 18$. See also a charter of Edward VI of 23 April 1550 in which the mayor and commonalty had the right to choose two coroners for Southwark, see Birch, n 3, p 121. For the coroner's court, see n 115.

${ }^{253}$ Halsbury, n 1, vol 29(2) para 44 notes that a person was disqualified from holding office as lord mayor so long as he was a coroner or deputy coroner for the City. See City of London Municipal Elections Act 1849 s 8A (added by the Coroners Act 1988 s 36(1), sch 3 para 1). Both these Acts have been repealed. CMC, n 14, p 77 (title unfounded).

${ }^{254}$ ' within the said city of London, and the liberties of the same, there be and shall be a certain office of register [sic] of all and for all sales and pawns, made or to be made to retailing brokers within the said city and liberties of the same; and for any goods, jewels, apparel, household stuff and other things so to be sold or pawned by any persons.' See Birch, n 3, pp 191-2.

${ }^{255}$ Norton, n 3, p 403.

${ }^{256}$ See Birch, n 3, pp 192-5. By letters patent of 13 January 1537, Henry VIII (1509-47) granted the hospital, lands and tenements to the mayor - and the mayor and aldermen were made governors of the same. See also Stow, n 3, pp 439, 448 and Pulling, n 3, p 243.

${ }^{257}$ See Wikipedia article on the same. The connection of the alderman with the governorship of the Bethlehem Hospital was severed in 1948 by the National Health Sevice Act 1946. See COL, n 3, p 48.

${ }^{258}$ This right did not arise from a charter and is a coronation custom. See Riley, n 3 (Munimenta, Liber Custumarum, pt 2), p 467; Bohun, n 1, pp 49-50 and Pulling, n 3, p 19. See also 1 Rolle's Reports 145 (81 ER 391). For occasions when the mayor exercised this right (or tried to do so) see Sharpe, n 30, vol 1, pp 88, 213, 275 and vol 2, pp 390, 508, 520, 540. See also Calthrop, n 3, p 118. For the tactless remarks of Bealknap CJ in 1377 to Londoners about the office of butler, see Preest (2005), p 37.

${ }^{259}$ COL, n 3, p 23 'Since the accession of King William IV [in 1830] there has been no coronation banquet, and the services in connection therewith have been dispensed with.' The attendance of the mayor at the coronation itself, and any duties of his in respect of the same, are not customs of the City as such, but coronation customs which are adjudged in the Court of Claims which meets prior to coronations. 
- Lord Lieutenant. The mayor is Lord Lieutenant of the City. ${ }^{260}$ When the sovereign desires to enter the City the mayor awaits her at the City boundary. The mayor surrenders the City sword (point downwards). On receiving it back, he bears it erect in processions before the sovereign. ${ }^{261}$ Further, no troops may pass through the City without the mayor's permission. ${ }^{262}$ These latter customs are customs not liberties (since there appears to be no grant by way of charter in respect of them). Also, one would assert they are 'ceremonial' customs only and not ones which have a legal effect that could be enforced in a court of law.

Today, the mayor nominally holds the above offices. However, all are now obsolete - apart from that of lord lieutenant. In particular, legislation should confirm the abolition of the following mayorial offices:
(a) chief magistrate;
(b) escheator;
(c) bailiff;
(d) admiral of the port of London;
(e) clerk of the market;
(f) keeper of the great beam;
(g) guager;
(h) outroper;
(i) coroner;
(j) registrar of pawns;
(k) custodian of Bedlam;
(i) butler at the coronation banquet of the sovereign. ${ }^{264}$

Further, it would not seem appropriate in modern times for the mayor (or aldermen) to act as JP's or for the mayor (or aldermen or sheriffs of the City) to sit as judges - in order to avoid any suggestion of undue influence.

In conclusion, legislation should provide for the abolition of certain obsolete offices held by the mayor, as well as confirm that the mayor (as well as the aldermen and sheriffs) shall no longer sit as a judge nor the mayor (and aldermen) as JPs.

\section{Liberty - To Elect Aldermen and Officials}

\subsection{Election of Aldermen}

Alderman likely derive from the Anglo-Saxon ealdorman (oldman) - itself deriving from the latin senex, being a reference to the Roman senator. ${ }^{265}$ The Constitutions of Edward II of 8 June 1319 provide that:

\footnotetext{
${ }^{260}$ Pulling, n 3, p 19 (in 1854) 'a position which has at various periods imposed very arduous and responsable duties upon him, though happily at the present day, he is not very likely to be called upon to act as head of the lieutenancy of the city in a military capacity.' See also COL, n 3 , pp 213-6 (lieutenancy of the City). The first commission of lieutenancy granted appears to have been in 1617, see Sharpe, n 30, vol 2, p 67. See also RC, n 14, vol 17, pp 188-9 \& vol 18, p 77.

${ }^{261}$ Calthrop, n 3, pp 124-5 'The mayors of London....are accustomed to have their sword bourn upright before them within the said City, and without the putting the same down in the presence of any, except the king, and that sword is called the king's sword.' In the case of Elizabeth II, the sword surrendered was the Pearl sword. This custom is said to date from 1215 and, thus, within the time of legal memory and not a legally enforceable custom which requires its origination prior to 1189. See Halsbury, n 1, vol 12(1), para 606.

${ }^{262}$ This custom would not appear to have originated prior to 1189 (see fn 261 above). COL, n 3, p 20 (in 1953) 'Subject to the permission, certain regiments, considered to have been recruited originally within the city, have the right to march with fixed bayonets and colours flying.' See Sharpe, n 30, vol 2, p 219 (position in 1895). It used to be a custom that a password to the Tower of London was sent, quarterly, to the mayor under the sovereign's sign manual. See RC, n 14, vol 18, p 25. This no longer occurs.

${ }^{263} \mathrm{eg}$. if the government needed to march troops through the City (during wartime for example), the mayor could not sustain in the courts a legal right (custom) to refuse them.

${ }^{264}$ The office of clerk of the market and any office relating to the coronation banquet should be cancelled generally, since others also hold such offices.

${ }^{265}$ See Anon, n 3, p 38 and Pulling, n 3, ch 3. The first mention of an alderman by name was in 1111, see COL, n 3, p 36. Also, CMC, n 14, pp $7-8$
} 
aldermen [shall] be removed from year to year, on the day of St Gregory the Pope [ie.12 March], and not re-elected; and others chosen by the same wards. ${ }^{266}$

These Constitutions also provide that alderman are to be taxed the same as other citizens. ${ }^{267}$ And, that the

aldermen are in charge of the common seal, viz:

that the common seal of the city remain in the custody of two aldermen and two others, commoners, to be chosen for this purpose by the commoners; and that that seal be not denied, neither to poor nor rich commoners, when they shall need it; yet so that they reasonably prove the cause of their demand: and that for the putting to of the seal nothing be taken. ${ }^{268}$

Finally, a $1^{\text {st }}$ charter of Edward IV of 9 November 1462 provides that aldermen (because of the great cost and trouble of being aldermen) are not to be put to any 'assizes, juries, attaints, recognizances or inquisitions out of the said city' nor be made a 'collector, assessor, taxer, overseer, or comptroller of the tenths, fifteenths, taxes, tallages, subsidies, or other charges or impositions ${ }^{269}$ Thus, the provisions in the charters in respect of aldermen are that:

- aldermen are to be elected annually and not re-elected;

- the common seal of the City is to remain in the custody of two aldermen and two commoners;

- aldermen are not to be put on any 'assizes, juries, attaints, recognizances or inquisitions' outside the City;

- aldermen are not to be made tax collectors.

In respect of these, the provision for the annual election of aldermen was repealed by an Act of $1393 .{ }^{270}$ The present position in respect of aldermen is that (theoretically) they hold office for life - unless they resign or are removed from office for just and reasonable cause. ${ }^{271}$ However, in practice, an alderman - on election - engages to resign his office on reaching 75 years old. Further, a convention has developed for aldermen to surrender their office after 6 years (in such circumstances they may stand for re-election in their wards). ${ }^{272}$ Thus, the provisions of the charters do not, in practice, apply. Further, alderman are no longer in charge of the common seal and they do not act as tax collectors. Also, assizes, attaints, inquisitions etc. are all obsolete.

In conclusion, the provisions in the charters of London relating to aldermen are obsolete.

\footnotetext{
${ }^{266}$ See Birch, $n$ 3, p 46. This wording was clarified in the $5^{\text {th }}$ charter of Edward III of 12 November 1376 to mean that 'every alderman of the said city, every year, for ever, on the feast of St Gregory the Pope, from the office of an alderman utterly and precisely shall cease, and shall not be chosen again; but that, instead of those removed, other aldermen shall be chosen every year, for ever, out of the discreet citizens of good fame, by the said wards from which the said aldermen were removed.' See also Birch, n 3, pp 66 \& xxviii.

267 'That the goods of the aldermen, in aids, tallages, and other contributions, concerning the said city, be taxed by the men of the wards in which those aldermen abide, as the goods of other citizens, by the said wards...that the mayor, aldermen, citizens and commonalty of the commoners of the city, and their heirs and successors, for the necessities and profits of the same city, may, among themselves of their common assent assess tallages upon their own goods within that city, as well upon the rents as other things, and as well upon the mysteries [trades] as any other way, as they shall see expedient, and levy them, without incurring the danger of us or our heirs, or our ministers whomsoever. And that the money coming from such tallages remain in the custody of four honest and lawful men of the city, to be chosen to this by the commonalty, and be laid out, of their custody, for the necessities and profits of the said city, and not otherwise.' See Birch, n 3, pp 49-50.

${ }^{268}$ Birch, n 3, p 48. Previously, the common seal had been in the hands of the mayor, see Sharpe, n 30, p 107. See also Pulling, n 3, pp 89-90. In 1778, the Common Council resolved that the common seal should only be applied with the authority of the Court of Common Council. By 1854 , three keys were kept in respect of the chest containing the common seal; they were held by the mayor, the chamberlain and a commoner. For the position in 1894, see RC, n 14, vol 18, p 38. See also COL, n 3, pp 7, 44, 51.

${ }^{269}$ Birch, n 3, pp 79-80. See also Norton, n 3, p 374 and Halsbury, n 1, vol 29(2), para 46.

${ }^{270}$ This process of annual election ended in 1355 and this was confirmed in 17 Ric II c 11 (1393, rep)(aldermen were to continue in office until removed for just and reasonable cause). See CMC, n 14, p 16; Norton, n 3, p 340 and RC, n 14, vol 18, pp 26-7. As to who elects aldermen, this was established by legislation in 1724 (11 Geo 1 c 18). See also RC, n 14, vol 18, p 364 and Coke, n 12, vol 4, p 253.

${ }^{271}$ Halsbury, n 1, vol 29(2), para 48. See also COL, n 3, p 39. The requirements as to an alderman being a freeman of the City and a British subject, as well as a suitable person to be a magistrate, are not laid down in any charter but in Acts of Common Council or ordinances. Ibid. ${ }^{272}$ Ibid.
} 


\subsection{Election of Chamberlain, Town Clerk and Common Sarjeant}

In respect of other City officials, although a charter of king John of 9 May 1215 reserved to the sovereign the right to appoint the chamberlain of the City, ${ }^{273}$ the Constitutions of Edward III of 8 June 1319 provide that:

the chamberlain, common clerk and common sarjeant [shall] be chosen by the commonalty of the city, and be removed according to the will of the same city... ${ }^{274}$

Today, the position is as follows:

- The chamberlain is elected by the Court of Common Hall; this appears to have been since $1492 ;{ }^{275}$

- The town clerk is elected by the Common Council; ${ }^{276}$

- The common serjeant is appointed by the Crown. ${ }^{277}$

In conclusion, the provisions of the charters in relation to the chamberlain, town clerk and common sarjeant are obsolete.

\subsection{Mayor's Sarjeants and the Mace}

A $4^{\text {th }}$ charter of Edward III of 10 June 1354 provides that:

the [mayor's] serjeants appointed to bear the maces in our said city may lawfully carry them of gold and silver, or silvered and garnished with the sign of our arms, or others, everywhere in the said city, and in the suburbs of the same, and in the county of Middlesex, and other places to the liberties of the said city appertaining. ${ }^{278}$ (italics supplied)

The bearing of these maces occured when greeting the sovereign ${ }^{279}$ and the right to bear maces of gold and silver was a great privilege when other maces were of copper. However, as Norton notes, it had no other import. ${ }^{280}$ As it was, many other towns soon carried silver (or silvered) maces - such as Exeter (in 1387), York (in 1396) and Norwich (in 1403). ${ }^{281}$ Further, since the $16^{\text {th }}$ century, it was almost universal practice for town and borough maces to be of silver or silvered. Today, there is no law preventing anyone from having a mace of any metal (the charter refers to 'lawfully'). Also, the words in italics are obsolete, no longer being within the Square Mile.

In conclusion, the provisions of the charters in respect of aldermen, other officers of the City and the metal of the sarjeants' maces are obsolete.

\footnotetext{
${ }^{273}$ viz. 'saving to us our chamberlainship.' See Birch, n 3, p 19. This is repeated in a 2nd charter of Henry III. See Birch, n 3, p 24. See also Stubbs, n 9, p 382; Petit-Dutaillis, n 9, p 101 ('These last words signify that the purveyors of the king's household shall have the right of making their choice, first of all, from the goods brought in by foreign merchants'). See also COL, n 3, p 109-13; Norton, n 3, p 318 and Ballard, n 5, p 5 .

${ }^{274}$ It also provides 'And the mayor and recorder, and the foresaid chamberlain and common clerk, be content with their fees anciently appointed and paid on account of their offices, and take not other fees for the abovesaid offices.' Also, 'That no sarjeant of the chamber of Guyhald [Guildhall] take fee of the commonalty of the city, or do execution, unless one chosen for this by the commonalty of the city.' These provisions are no longer relevant. See also Riley, n 3 (Munimenta, Liber Albus III), p 7.

${ }^{275}$ Halsbury, n 1, vol 29(2), para 57 and Norton, n 3, pp 343-4. The chamberlain, today, is treasurer of the funds of the City and keeps the accounts. He also maintains the roll of freemen and admits persons to the freedom of the City. See also CMC, n 14, p 51.

${ }^{276}$ Ibid, para 58. See also RC, n 14, vol 18, pp 70-1 and CMC, n 14, p 39.

${ }^{277}$ He was formerly appointed by the Common Council but this was changed by the Local Government Act 1888. Such a person is a circuit judge, see Courts Act 1971, sch 2 para 2(2). See also Halsbury, n 1, vol 29(2), para 57. Thus, he is no longer a City official. Cf. CMC, n 14, p 38. ${ }^{278}$ See Birch, n 3, p xxvii (all other cities and towns could only use copper maces, by royal precept). See also Pulling, n 3, p 17 and Coke, n 12 , vol 4, p 252.

279 'to meet with us, our mother, consort, or the children of us or our heirs, or other royal persons, when we or any of us shall come to the said city, and also in going forth with us, or any of us, when we shall depart from the said city; as also in the presence of us, our mother, or consort, or our children, when the said mayor, or sheriffs, or aldermen of the said city, or any of them, shall come to us or our heirs, at or without the command or warning of us, or of any of us; and as often as it shall happen any of the said serjeants to be sent to foreign places, and without the city, to do their offices at the command of us, or of the mayor and sheriffs aforesaid, they may lawfully carry, going and coming publicly, as our own sarjeants at arms, attending our presence, do carry their maces; any ordinance or commandment made to the contrary notwithstanding.' See Birch, n 3, pp 63-4.

${ }^{280}$ Norton, n 3, p 366.

${ }^{281}$ For a useful article, see wikipedia (maces). Maces were generally a sign of royal authority in England. Also, macebearers may have originally been executors of legal process. Hence, there may have been some legal restriction.
} 


\section{Grants of Land to the Citizens of London}

The original 'City of London' which received liberties from sovereigns was small. ${ }^{282}$ The geographical ambits of the City later expanded as more land was acquired by the City. This is reflected in the charters. Thus,

- in 1132, Henry I (1100-35) granted the farm of Middlesex to the citizens of London for $£ 300$;

- in 1227, the brother of Henry III (1216-72) granted the farm of Queenhithe to the citizens for $£ 50$;

- in 1327, Edward III (1327-77) granted the farm of part of Southwark (the Guildable Manor) to the citizens for $£ 10$ and, in 1550 , the mayor and commonalty purchased the manor of Southwark, which comprised almost all the rest of it;

- in 1444, Henry VI (1422-71) confirmed to the citizens (by patent) all the soils, streets etc of the City.

This position, reflected in the charters in more detail, is as follows:

- Middlesex. A $1^{\text {st }}$ charter of Henry I of 1132 granted to the citizens the farm of Middlesex for $£ 300 .{ }^{283}$ This rent owed to the Crown was later alienated. By 1854, it was in the hands of Sir William Rush and the rent was paid to him by the sheriffs. However, by 1929, it had been redeemed. ${ }^{284}$ Today, the Square Mile does not contain Middlesex;

- Liberty of St Pauls. A $6^{\text {th }}$ Charter of Henry III of 12 June 1253 provides that, out of the farm of London and Middlesex, there is to be allowed a reduction of $£ 7$ for the liberty of St Paul's London. ${ }^{285}$ This soke (exclusive jurisdiction) no longer exists;

- Queenhithe. A charter of Henry III of 26 February 1247 confirms a grant between Richard, Earl of Cornwall (his brother) and the mayor and commonality of the city of London in which the Earl grants to them 'Queenhithe, with all their liberties, customs, and other things to the same belonging, in fee farm' with the City paying $£ 50$ annually to the Earl and his heirs and assigns. ${ }^{286}$ This is no longer paid. Presently, Queenhithe is one of the wards of the City;

- Southwark. A $2^{\text {nd }}$ charter of Edward III of 6 March 1327 notes that the village of Southwark was an area notorious for harbouring felons, thieves and other malefactors. At the petition of the City, and 'for the confirmation of our peace within the city, bridling the wickedness of the said malefactors', Edward III (1327-77) grants the village to the citizens at a farm of $£ 10 .{ }^{287}$ This village was nearest to the south side of London Bridge and was known as the Guildable Manor (Southwark comprising, at the time, this manor, the King's Manor and the Great Liberty Manor). ${ }^{288} \mathrm{~A} 1^{\text {st }}$ charter of Edward IV of 9 November 1462 confirms this grant as well as various franchises to the mayor and commonalty of the City in respect of Southwark, viz. waif, estray, treasure, goods and chattels of traitors, felons and outlaws, all disclaimed and found goods, escheats, forfeitures, assize of bread and other victuals, all that relates to the clerk of the market or to the king's house, and all trades and forfeitures, fines and amercements relating to the same. ${ }^{289}$ Also, the execution of writs, the right to hold a fair and court of piepowder for 3 days; and the right to take thieves to Newgate. ${ }^{290}$ Also, all franchises, liberties etc which the sovereign would have had, had the

282 See n 121

283 'I have granted to my citizens of London, to hold Middlesex to farm for [£300], upon accompt to them and their heirs.' See Birch, $\mathrm{n} 3$, pp

$3-4$.

284 See $n 76$.

285 'we will and command, for us and our heirs, that, out of the farm of our city of London, there be allowed to our sheriff of the said city yearly, in his said account, [£7], at our exchequer .for the liberty of St Paul's, London.' See Birch, n 3, pp 34-5 \& p xviii. See also Riley, n 3, (Chronicles), p 21. For the purchase of St Paul's churchyard in 1878, see COL, n 3, p 189.

${ }^{286}$ Birch, n 3, pp 32-3; Riley, n 3, (Chronicles) pp 13 \& 21 and Pulling, n 3, p 354. Queenhithe is situated on the Thames to the south of St Paul's (the Millenium bridge crosses into the City at Queenhithe). The dock was used for bringing corn, and fur, into the City but is now dis-used. See also Norton, n 3, pp 321-2 and Page, n 3, p 38.

287 'we.would grant unto them the said village, to have to them...for ever, for the farm and rent therefor yearly due to us, to be yearly paid at our exchequer.' See Birch, n 3, pp 59-60. The sum of $£ 10$ rent was redeemed in 1929, see COL, n 3, p 79. Also, n 76.

${ }^{288}$ Sharpe, n 30, vol 1, p 441. See also COL, n 3, p 79. As Norton, n 3, p 363 notes, this charter of 1327 simply grants bailiff's jurisdiction over the village of Southwark. It was not until the later charter of 1462 (see text above) that judicial and seignorial rights were granted. Inwood, $\mathrm{n}$, p 129 'The taxable area was small, extending about 500 yards along the riverfront, and 100 yards southwards from the bridge. This was the borough proper, the 'Guidable Manor', controlled by the Earls of Surrey and the king's bailiff.'

${ }^{289}$ Birch, n 3, pp 81-2.

${ }^{290}$ Ibid, pp 82-3. Also a 'view of frankpledge, and whatsoever thereto pertaineth.' Views of frankpledge and courts of pie powder (pie poudre) held at fairs were suspended by the Administration of Justice Act, s 23. Newgate was closed in 1904, see n 199. The fair at Southwark was suppressed in 1762, see CMC, n 14, p 19. 
town remained in the sovereign's hands. ${ }^{291}$ A charter of Edward VI of 23 April 1550 grants the manor of Southwark to the City together with liberties similar to those cited in respect of the above charter of $1462 .{ }^{292}$ After this charter of 1550 , the City now had all of Southwark apart from: (a) the King's Place (called Southwark Place or Suffolk House, formerly the Duke of Suffolk's mansion) and; (b) the prisons of King's Bench and Marshalsea (both no longer exist). Southwark then became a ward of the City (the ward of Bridge Without). However, the inhabitants never had any part in electing an alderman because of disputes and their refusal to take up the freedom of the City and bear the burdens of citizenship. ${ }^{293}$ As a result of successive boundary changes, Southwark is not part of the Square Mile today; ${ }^{294}$

- Blackfriars etc. A $2^{\text {nd }}$ charter of James I of 20 September 1608 extends the liberties of the City through the parish of Trinity near Aldgate or Duke's Place, St Bartholomew (Great and Little), Blackfriars, Whitefriars and Cold Harbour - together with their inhabitants; ${ }^{295}$

- Moorfields and West Smithfield. A $1^{\text {st }}$ charter of Charles I of 18 October 1638 grants to the mayor the fields of Moorfields and West Smithfield, together with the liberty to hold fairs and markets in those fields and all tolls, profits etc ${ }^{296}$ Today, there is no longer a market in Moorfields and Smithfield market is outside the Square Mile (albeit the Corporation of London runs it);

- Other Lands. In a $3^{\text {rd }}$ charter of Edward III of 20 June 1478, the king grants to the mayor, commonalty and citizens the right to purchase lands in mortmain to the annual value of 200 marks. ${ }^{297} \mathrm{~A} 1^{\text {st }}$ charter of Charles I of 18 October 1638 grants a licence to the mayor, commonalty and citizens the right to purchase 5 acres in the parish of St Giles-in-the-Fields in the county of Middlesex; ${ }^{298}$

- Streets of the City. Henry VI (1422-71), in letters patent of 26 October 1444, grants to the citizens all soils, streets etc of the City. ${ }^{299}$ Although an Act of 1449 voided all grants of lands and tenements by Henry VI, making the status of this patent uncertain, it was confirmed in letters patent of Henry VII (1485-1509) of 23 July $1505 .{ }^{300}$ Doubts still existing, the grant is confirmed in a $1^{\text {st }}$ charter of Charles I of 18 October $1638^{301}$ which confirms to the mayor and commonalty all messuages and houses erected on void grounds within the City and liberties. ${ }^{302}$ Today, these charters are limited by the fact that the City

\footnotetext{
${ }^{291}$ Ibid, p 84 (reserving the rights of the archbishop of Canterbury, which were extinguished by 1538, see note below).

${ }^{292}$ Ibid, pp 110-27 \& xxxv. In 1536, Henry VIII (1509-47) acquired the priory of Bermondsey (Great Liberty Manor) and in 1538 the property of the Archbishop of Canterbury in Southwark (King's Manor). See also Norton, n 3, pp 386-9 and Inwood, n 3, p 187-91.

${ }^{293}$ Sharpe, n 30, p 443. See also Norton, n 3, p 389; RC, n 14, vol 18, pp 359-61 (in 1894) and COL, n 3, p 26 (in 1953).

${ }^{294}$ See a useful article on Southwark in wikipedia.

${ }^{295}$ See Birch, n 3, pp 143-4.

296 'the said mayor and commonalty and citizens... may have, hold and enjoy all those fields, called or known by the name Inward Moor and Outward Moor, in the parish of St Giles without Cripplegate, London; St Stephen, in Coleman Street, London; and St Botolph without Bishopsgate, London; or in some or any of them; and also all that field called West Smithfield, in the parish of St Sepulchre's, St Bartholemew the Great, St Bartholemew the Less, in the suburbs of London, or in some of them, to the uses, intents and purposes after expressed; and that the same mayor and commonalty and citizens, and their successors, may be able to hold in the said field called Smithfield, fairs and markets there to be and used to be held, and to take, receive, and have pickage, stallage, tolls, and profits appertaining, happening, belonging, or arising out of the fairs and markets there, to such uses as the same mayor and commonalty of citizens...' See Birch, n 3, pp 177-80 \& xxvii. Stow, n 3, p 380 (writing in 1603) noted that Moorfields was a great fen (or moor) which was waste ground until a gate was opened onto it in 1415. See also Jacob, n 3, p 82.

${ }^{297}$ See Birch, n 3, pp 87-9 \& xxv. Also, Norton, n 3, p 379. Mortmain was the the alienation of lands and tenements to any guild, corporate body or fraternity, and their successors. The Mortmain Acts were abolished in 1960.

${ }^{298}$ Ibid, pp 195-7.

299 'all soils, commons, purprestures and improvements in all wastes, commons, streets, ways and other places in the city and suburbs aforesaid, and in the water of the Thames within the limits of the same city, together with the profits of the same purprestures and improvements, and that they may improve, and enjoy the rents of them, and their successors for ever.' See Birch, n 3, p 167; Norton, n 3, p 372 and COL, n 3 , p 54.

${ }^{300}$ See Birch, n 3, p 168.

${ }^{301}$ See Norton, n 3, pp 372-3 and Birch, n 3, pp 166 \& 176-7.

302 'grant and confirm to the said mayor and commonalty, and citizens of the said city, all messuages, houses, edifices, cottages, buildings, courts, yards, gardens, conduits and cisterns, shops, sheds, porches, benches, cellars, doors of cellars, staples, stalls, stages, pales, posts, jutties, and penthouses, signposts, props of signs, and the ground and foundation of them, shores, watercourses, gutters and easements, with their appurtenances, which now are, or at any time hereafter shall have been erected, built, taken, enclosed, obtained, increased, possessed or enjoyed by the said mayor and commonalty and citizens and their successors, or any person or persons whatsoever of, in, upon or under all or any void grounds, wastes, commons, streets, ways and other common places within the said city, and the liberties of the same, and in the river or water of Thames, or ports, Banks, creeks, or shores of the same, within the liberties of the said city.' See Birch, n 3, pp 176-7. See also COL, n 3, p 54.
} 
now only comprises the Square Mile. Further, the City is no longer farmed for $£ 3000^{303}$ Given this, as Norton noted in 1869, it would seem that land in the City is held by the residents as freehold owners of their properties. Further, the streets and waste would not belong to the sovereign, save as lord paramount. $^{304}$

None of these charters are applicable today since the City (for the purpose of any liberties) encompasses only the Square Mile. Further, its geographical limits have been fixed by statute, with a number of boundary changes.

\section{Liberty - Hunting}

A charter of Henry I of 1132 provides:

the citizens of London may have their chaces [chases] to hunt, as well and fully as their ancestors have had, that is to say, in Chiltre, and in Middlesex and Surrey ${ }^{305}$

Chiltre (or Ciltre) is thought to be a reference to the Chilterns. ${ }^{306}$ This right of hunting was confirmed in later charters. ${ }^{307}$ A $5^{\text {th }}$ Charter of Henry III of 18 August 1227 provides:

we have granted, and by this present charter confirmed...unto our archbishops, bishops, abbots, priors, earls, barons, knights, freeholders, and to all the county of Middlesex, that all the Warren of Staines, with the appurtenances, be unwarrened and disforested for ever, so that all the aforesaid, and their heirs and successors, may have all liberties and benefit of warren and forest, in the aforesaid warren, wherein they may till or plough all their lands, and cut all their woods, and dispose of the same at their will, without the view or contradiction of our warreners or foresters, and all their ministers, and within the which no warrener or forester, or justice of our forest, shall or may in any wise meddle with their lands and woods etc. $^{308}$

As noted by Norton, this is not really a City charter as such. ${ }^{309}$ In respect of hunting, until 1723 , there was a common huntsman (called Common Hunt) who's responsibility it was to take care of the pack of hounds belonging to the mayor and citizens. ${ }^{310}$ This office was abolished in 1807 by order of the Common Council. ${ }^{311}$ Today, no common hunt exists. Nor does the City have jurisdiction over the hunting areas referred to in the charters. ${ }^{312}$ Finally, franchises of free warrens, free chases and free parks were abolished by the Wild Creatures and Forest Laws Act 1971. ${ }^{313}$

In conclusion, this liberty in respect of hunting is obsolete.

${ }^{303}$ See $\mathrm{n} 76$.

${ }^{304}$ Norton, n 3, p 400.

${ }^{305}$ See Birch, n 3, p 4. Cf. Robertson, n 21, p 293 (alternative translation) 'the citizens shall enjoy as good and full hunting rights as their ancestors ever did, namely, in the Chilterns, Middlesex and Surrey.' See also Ballard, n 5, p 83.

${ }^{306}$ Bohun, n 1, p 34. Cf. Fitzstephen (1173), 'The citizens have the right of hunting in Middlesex, Hertfordshire, all the Chilterns and Kent, as far as the river Cray.' See also Stow, n 3, p 509 and Stenton, n 20, p 58.

307 (a) charter of Henry II of c. 1155 ('I do grant to them, that they may have their huntings wheresoever they had the same in the time of [Henry I]).' See Birch, n 3, p 6; (b) $1^{\text {st }}$ charter of Richard I of 23 April 1194, ('we have granted to them, that they may have their huntings wheresoever they had the same in the time of [Henry I]).' See Birch, n 3, p 8; (c) $1^{\text {st }}$ charter of John of 17 June 1199 ('and we do grant unto them, that they may have their huntings, wheresoever they had the same in the time of [Henry I]. See Birch, n 3, p 12; (d) $4^{\text {th }}$ Charter of Henry III of 16 March 1227 ('they may have hunting wheresoever they had in the time of [Henry I]'). See Birch, n 3, p 29. Also, Gomme, n $3, \mathrm{p} 254$.

${ }^{308}$ See Birch, n 3, pp 30-1. See also Stow, n 3, p 374.

${ }^{309}$ Norton, n 3, p 320 'it is granted to all the free tenants of the county of Middlesex of every rank, and does not specify the citizens of London by name.'

${ }^{310}$ Bohun, n 1, p 70 .

${ }^{311}$ Sharpe, n 30, vol 1, p 332. See also COL, n 3, p 5.

${ }^{312}$ For the Warren of Staines, see Page (1911), pp 253-8. In 1545, Henry VIII (1509-47), by proclamation, forbade public hunting and hawking in the suburbs of London, see Sharpe, n 30, vol 2, pp 403-4.

${ }^{313}$ See $\mathrm{s} 1$. 


\section{Liberties - Billeting and War}

\subsection{Billeting}

In early times, sovereigns - using the king's marshall ${ }^{314}$ - would billet troops, members of the royal household and foreign dignatories in the homes of citizens when adequate accommodation could not otherwise be found. This was particularly so in respect of events such as coronations. ${ }^{315}$ Naturally, this was bitterly resented by citizens who were not compensated. ${ }^{316}$ A charter of Henry I (1100-35) of 1132 provides:

none shall lodge within the walls, neither of my household, nor any other, nor lodging delivered by force. ${ }^{317}$

This provision is obsolete. The Petition of Right 1627 prevents the billeting of troops on the general public ${ }^{318}$ and billeting is now regulated by legislation (with compensation being payable; also it no longer applies to private residences). ${ }^{319}$ As for the king's household, it is much depleted and there are seven royal palaces available for their accommodation as well as for foreign dignatories. ${ }^{320}$ Further, any form of purveyance was abolished by the Tenures Abolition Act 1660. ${ }^{321}$

\section{$12.2 \mathrm{War}$}

A charter of Edward II of 12 December 1321 exempts London citizens from levies of men for carrying on war outside the City - though the wording is opaque. ${ }^{322}$ More specifically, a $1^{\text {st }}$ charter of Edward III of 6 March 1327 provides:

citizens, from henceforth shall not be compelled to go or send to war out of the said city. ${ }^{323}$

As Pulling notes, the reason for this is likely that - since the City was held in free burbage - the citizens were bound only to defend their own walls. ${ }^{324}$ As it was, this liberty of the citizens of London being free from impressments in

\footnotetext{
314 The marshal of the king's household helped manage the royal household and (with the Steward of the King's household) sat in judgment in the court of Marshalsea (a court abolished in 1849). See Walker, n 27 (marshal of the king's household) and Norton, n 3, p 287.

${ }^{315}$ See, eg. Letterbook C, n 3, xciii (also in Riley, n 3, (Memorials), pp 64-5)) 'The hostels in the City of London, which were taken by the marshals of Lord King Edward [Edward II] ...for lodging the great folks, native and foreign, who had come to the coronation [on 24 February 1308] ...were by award of him, our lord the King, and his council, given up on the Thursday following; it being understood that if the parties occupying the them should wish to make any further stay, they were to make recompense to the owner of the house for the same, etc'. See also Riley, ibid, pp 125-6 (in 1317).

${ }^{316}$ Indeed, it was a rule in London that, if a citizen killed someone who had entered his house, he might acquit himself with [6] kinsmen if he swore he had killed the man because he had been billeted on him without his consent. See Bateson, n 5, vol 2, p xxviii \& vol 1, p 47. Also, Riley, n 3 (Munimenta, Liber Albus), pp lviii-lix.

317 See also: (a) charter of Henry II ('no man shall take lodging by force, or by delivery of the [king's] marshall.'). See Birch, n 3, p 5; (b) $1^{\text {st }}$ charter of Richard I of 23 April 1194 ('none may take any lodgings within the walls of the city by force, or by delivery of the marshall.'). See Birch, n 3, p 7; (c) $1^{\text {st }}$ charter of John of 17 June 1199 ('within the walls of the city or portsoken, no man shall take lodging by force, or delivery of the marshall.'). See Birch, n 3, p 11; (d) $4^{\text {th }}$ Charter of Henry III of 16 March 1227 ('within the walls of the city and portsoken, no man may take any lodging by force, or by delivery of the marshal.'). See Birch, n 3, p 28; (e) $8^{\text {th }}$ Charter of Henry III of 26 March 1268 ('within the walls of the city and in portsoken none may taken lodgings by force, or delivery of the marshal.'). See Birch, n 3, p 39. See also Seyer, $\mathrm{n}$ 157, p 6 (charter of Bristol with similar provision).

${ }^{318}$ See Petition of Right 1627, s 8 and McBain (2011b), pp 96-100.

${ }^{319}$ See the terms of the Army Act 1955 and Air Force Act 1955. See Halsbury, n 1, vol 2 (2), para 126 and McBain, n 318, p 98. This liberty granted to the citizens of London was not always observed and they had troops billeted on them during the Civil War, for example. See Sharpe, n 30, vol 2, pp 294, 297 and Inwood, n 3, p 235 (occupation of the City in December 1648 and February 1660).

${ }^{320}$ London had few hostels (common inns) in medieval times. The position is the reverse in modern times. In any case, the Square Mile has virtually no residential accommodation.

${ }^{321}$ See $\mathrm{n} 172$.

322 'whereas the mayor and the good men of the city of London have of late thankfully done us aid of armed footmen at our castle at Leeds...and also aid of like armed men now going with us through divers parts of our realm for divers causes: we, willing to provide for the indemnity of the said mayor and men of our city of London in this behalf, have granted to them for us and our heirs, that the said aids, to us so thankfully done, shall not be prejudicial to the said mayor and good men, their heirs and successors, nor shall they be drawn into consequent[ce] for time to come.' See Birch, n 3, pp xxv \& 51 and Sharpe, n 30, vol 1, p 151. London supplied 500 men to besiege Leeds castle the wife of whose owner (Bartholemew Badlesmere) had refused admission to the wife of Edward II. See generally, Haines (2003), pp 32-3 and Phillips (2010), p 398. ${ }^{323}$ See Birch, n 3, p 55. This right may have derived from an older Anglo-Saxon right of fyrdfare which was quittance of going with the host (army). See Fleta, n 144, p 102. See also Ballard, n 5, p xlviii.

${ }^{324}$ Pulling, n 3, p 68.
} 
the army or navy was often ignored by sovereigns. ${ }^{325}$ Impressment for the army - which was by legislation ended in 1780 and impressment for the navy was abandoned in $1814 .{ }^{326}$ Impressment for the navy by order of the Crown is still (technically) possible. However, it is long obsolete ${ }^{327}$ and, today, any forcible conscription of civilians into the armed forces would require legislation.

In conclusion, liberties in respect of billeting and war are obsolete - these matters being regulated by statute.

\section{Liberty - Freedom from Tolls ${ }^{328}$}

In medieval times, the imposition of tolls was very common. It was the means by which lords of the manor and boroughs financed themselves - and tolls were often onerous. Pollock and Maitland, writing in respect of the reign of Edward I (1272-1307), ${ }^{329}$ stated:

Powers of taxation are not expressly conceded by the charters of this age, and they must have been confined within narrow limits. If the burgesses wished to repair their walls, their bridges, their streets, they had to apply to the king for a grant of murage, pontage or pavage; and such grants were not to be had as matters of course. In Edward I's day the petition came before the royal council in parliament, and the 'local rate', we may say, was frequently a 'parliamentary tax'; but as the king had not yet lost the right to tallage his boroughs, he could permit them to tallage [ie. tax] themselves...A large part of the borough's revenue was derived from tolls, if we use the term in its largest sense to include 'passage, pontage, lastage, stallage, bothage [sic], ewage, tronage, scavage' and the like. Naturally a borough community intrusted with the farm of tolls was tempted to impose a stringent and protective tariff: its ideal of a perfectly 'free' trade was an unlimited power to tax other people. Nevertheless we may doubt whether it had any right to create new tolls.

A full list of all medieval tolls would be difficult to compile. However, they include the following:

(a) Market Tolls

- stallage

- $\quad$ piccage (pickage)

- $\quad$ tronage (pesage);

- scavage (showage);

- lastage (lestage)

- for erecting (or having) a stall in a fair or market; ${ }^{330}$

- for breaking the ground to erect a stall, ${ }^{331}$

- for weighing goods on a public scale; ${ }^{332}$

- toll on goods offered for sale; ${ }^{333}$

- toll on traders at fairs, to carry goods; ${ }^{334}$

\footnotetext{
${ }^{325}$ Demands on the City to provide men for wars in France were frequent although they did, sometimes, protest. See eg. Sharpe, vol 1, n 30, pp 371, 411 \& 479 and vol 2, p 103. See also Norton, n 3, p 153, CMC, n 14, p 120 and Pulling, n 3, pp 22, 68.

${ }^{326}$ See McBain (2011c), pp 14-37. See also McBain (2012b), pp 55-7.

${ }^{327}$ Ibid, pp 18-20.

${ }^{328}$ For texts on tolls, see Forbes (1902); Gunning (1833); Woolrych (1829).

${ }^{329}$ Pollock, n 133, vol 1, pp 661-3.

${ }^{330}$ Halsbury, n 1, vol 29(2) para 1036, 'Stallage is the appropriate term for payment for the liberty of placing a stall on the soil or for standing room for cattle or goods within the market or fair.' OED, n 26, 'A tax or toll levied for the liberty of erecting a stall in a fair or market.' Gunning, $\mathrm{n} 328, \mathrm{p} 85$ 'Stallage is a duty for the liberty of having stalls in a fair or market, or for removing them from one place to another.' See also Pease, n 218 , ch 4 .

${ }^{331}$ Ibid 'When the soil is broken, the payment is often called piccage.' There is also pennage 'a sum payable for the liberty to erect pens. However, piccage and pennage are merely names for particular varieties of stallage.' OED, n 26, 'A toll paid for breaking the ground in setting up booths, stalls, tents etc at fairs.' Gunning, n 328, p 85 'Pickage is a duty for picking holes in the lord's ground, for the posts of the stalls.'

${ }^{332}$ To prevent the selling of goods at underweight, from early times there was established in London the king's beam (or tron), the common beam and the small beam, see n 224. A king's beam (tron) had been established in London, at least, from 1245, see Riley, n 3 (Chronicles), pp 13-4 (prior and canons of St Bartholomew's sought to set up a new tron). See also, pp 27, 37 (1256, method of weighing) and p 123 (foreigners fined for trying to avoid using the tron in 1269). Pesage seems to have been a toll for weighing less heavy commodities, where the term tronage was applied. See Pease, n 218, p 56.

${ }^{333}$ See n 233. See also Riley, n 3 (Munimenta, Liber Custumarum, pt 2), p 722 and Pease, n 218, p 56 'Scavage or shewage: toll paid for a licence to show or expose wares.' There was also sumage (summage), a toll paid for carrying goods on horseback and toll turn, a toll paid for cattle or goods on their return from a fair or market, ibid, $\mathrm{p} 56$.

${ }^{334}$ OED, n 26, 'A toll payable by traders attending fairs and markets.' Pease, n 218, p 56 'Lastage or Lestage: a toll paid for liberty for persons to carry their goods up and down to markets and fairs.' The 'last' (from the Anglo-Saxon, last, a burden) was a measure by which several kinds of solid goods were sold. See Norton, n 3, p 287. It is also spelt 'lestage.' However, lastage (lestage) was also a port toll (duty). OED, n 26, a 'payment for liberty to load a ship; a port duty.' See also Riley, n 3 (Munimenta, Liber Custumarum, pt 2), pp 737, 811-2. See also Hargrave (1787), p 75 'lestage, that were port duties of goods unladen.' Seyer, n 157, p 6 (lastage is what we now call porterage).
} 
(b) Water Related Tolls ${ }^{335}$

\begin{tabular}{|c|c|}
\hline $\begin{array}{l}- \\
- \\
- \\
- \\
- \\
-\end{array}$ & $\begin{array}{l}\text { - for using a crane; }{ }^{336} \\
\text { - for using a wharf; } ; 37 \\
\text { - for the anchoring of ships;,;38 } \\
\text { - for the loading of ships, } ;^{339} \\
\text { - ships' pilot dues, levied on goods; }{ }^{340} \\
\text { - levied on vessels lying on shore or entering a port; }{ }^{341} \\
\text { - for ferrying over water; }{ }^{342}\end{array}$ \\
\hline
\end{tabular}

It should be noted that 'passage' - although first used in the case of traversing water - became, in time, a generic term to also refer to the passage of persons along roads and across bridges. Passage was divided into and toll through and toll traverse. The former applied to public ferries, highway and bridges, ${ }^{343}$ the latter to ones in private ownership over which the public was allowed access over. ${ }^{344}$

(c) Road and Bridge Tolls

- pontage (pontagium)

- passage;

(d) City Wall and Paving Tolls

- murage (muragium)

- pavage (pavagium)

(e) Forest and Animal Tolls

- for building (or repairing) bridges; ${ }^{345}$

- for building (or repairing) roads, bridges and ferries; ${ }^{346}$

- for building (or repairing) city (or town) walls; 347

- for paving highways and streets; ${ }^{348}$

${ }^{335}$ See generally, Forbes, n 328, ch 9. Tolls for harbours, lighthouses, docks, piers and canals have long been statutory. See also Moore (1888), pp 356-7 quoting Hale's treatises on Ports and Customs.

${ }^{336}$ OED, n 26 'Dues paid for the use of a crane.' See also Forbes, n 238, p 571; Gunning, n 328, p 122 and Hargrave, n 334, p 76 'Cranage, or duty for the taking up or lading on a ship any goods or merchandise by that engine.'

${ }^{337}$ Ibid, 'The charge or dues exacted for the use of a wharf.' Forbes, n 238, p 571 'Wharfage is a toll or duty for the pitching or lodging of goods upon a wharf, or 'money for landing goods on a wharf or quay, or for shipping or taking goods into a boat from thence.' See also Hargrave, $\mathrm{n}$ 334, p 76 and Jeake (1728), p 57 (kaiage or keyage).

${ }^{338}$ Ibid, 'A toll or charge for anchoring; anchorage- dues.' Forbes, n 238, p 562 'A toll for anchoring a vessel in the port.' Forbes, p 562 also mentions ballastage (taking ballast from the bottom of the port); busselage (a toll claimed at the port of Hull); keelage (for vessels coming within ports), petty loading and petty customs (customs on merchandise at Exeter port) - all long obsolete. See also Hargrave, n 334, pp 74-6 who also mentions moreage (mooring ships), terrage or tenage (unloading goods before they come up to the quay), hostellage (use of a warehouse), pesage (weighing of merchandise), tronage (weighing of wool), measurage (measuring dry or wet imported goods). There is also porterage (for carrying goods), lighterage (unloading goods from a ship by means of a lighter) and cooperage (making, and repairing, storage casks).

${ }^{339}$ Ibid, 'A toll or due for loading.'

${ }^{340}$ Ibid, 'A small duty formerly paid to a local society of pilots, as at Newcastle-on-Tyne.' The latter duty ended in 1865 . See also Forbes, $\mathrm{n}$ 328, p 569 and Hargrave, n 334, p 74. Primage was also payment to the ship's captain for the use of cables and ropes and to the mariners for working them.

${ }^{341}$ Ibid, 'A duty levied on vessels lying upon a shore or beach, or entering a port.' Also, called (it seems) terrage, see Jeake, n 337 , p 57.

${ }^{342}$ Ibid. 'A charge or custom levied upon passengers, a toll'. Webb's Case (1612) 8 Coke's Reports 46b (77 ER 541) ('passagium, that is properly a ferry for the passage of men and cattle over water, for which the owner has a toll.'). See also Norton, $n$ 3, p 287. See also Seyer, $n$ 157, pp 1-2 'Passage signifies money paid for crossing a river or (as it is sometimes used) for crossing the sea. It is over water, as way is over land; see 4 Edw 3 cap 8.' Ewage (acquage) was also used to describe a toll for passage across wáter. OED (ewage) 'ewagium, the same with acquage which is a toll paid for water passage.' See also Forbes, $\mathrm{n} 328$, pp 501-15.

${ }^{343}$ See Gunning, n 328, ch 2 and Forbes, n 328, p 547. Also, Pease, n 218, p 56.

${ }^{344}$ Ibid, ch 3. See also Forbes, n 328, p 547

${ }^{345}$ OED, n 26, 'A toll paid for the use of a bridge; a tax paid for the maintenance and repair of a bridge or bridges, bridge-toll.' See McBain, $\mathrm{n}$ 4 , for the contention that this is obsolete. This toll was called 'bridgetol' (bridtol) and quittance from it 'bridgebot.' See n 144. See also Forbes, n 328, pp 516 et seq.

${ }^{346}$ Turnpike trusts which charged road tolls and were initiated by an Act of Parliament in 1706, were no more by the end of the 19th century. See HW Woolrych, n 238, ch 7. London street tolls were abolished in 1856 by an Act of Common Council. See RC, n 14, vol 18, p 196 and Allen, n 3, pp 42, 48.

${ }^{347}$ OED 'A toll or tax levied for the building or repairing of the walls of a town.' Freedom from this toll was called by the Anglo-Saxons, burghbot. See Fleta, n 144, p 102 and Coke, n 12, vol 1, s 109a. Also, McBain, n 4.

${ }^{348}$ Also spelt paviage. OED 'A tax or toll towards the paving of highways and streets.' See also C Welch, History of the Worshipful Company of Paviors (published by the same, 1909). 


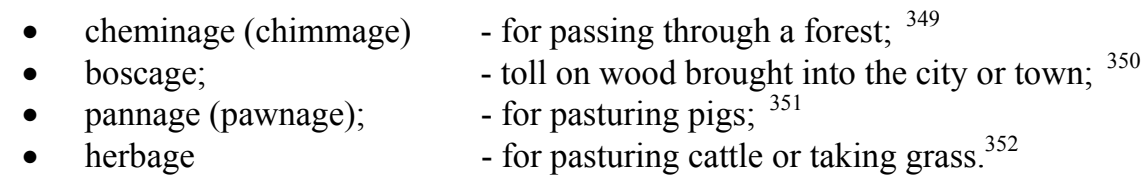

In the case of the city of London, from an early date, its citizens sought to be free (quit) of all tolls. Thus, a charter of Henry I (1100-35) of 1132 provides that:

all the men of London shall be quit and free, and all their goods, throughout England, and the ports of the sea, of and from all toll and passage and lestage [lastage], ${ }^{353}$ and all other customs... And if any shall take toll or custom of any citizen of London, the citizens of London in the city shall take of the borough or town, where toll or custom was so taken, so much as the man of London gave for toll, as he received damage thereby. ${ }^{354}$

The second paragraph refers to withernam, from the Anglo-Saxon words 'wither' and 'nam'. It signified a right to seize chattels in lieu of those unjustly taken or detained (ie. reprisal or retaliation). ${ }^{355}$ This liberty to be exempt from tolls was later expanded to cover the dominions of the sovereign beyond the seas. ${ }^{356}$ Thus, an $8^{\text {th }}$ charter of Henry III of 26 March 1268 provides that

we have also granted to our said citizens throughout all our dominions, wheresoever they come to dwell with their merchandises and things, and also throughout all the sea-ports, as well on this side as beyond the seas, they shall be free of all toll and lastage, and of all customs, except everywhere our due and ancient custom and prices [prises] of wines... and if any in any of our lands, on this side or beyond the seas, or in the ports of the said sea, on this side or beyond the seas, shall take of the men of London toll, or any custom, contrary to this

\footnotetext{
${ }^{349}$ Also spelt, chiminage. OED n 26, 'A toll formerly paid for liberty of passage through a forest.' Coke, n 12, vol 4, p 306 'a toll for way-faring men through a forest, derived from the the French word chemin for a way.' See also Carta de Foresta (1297) c 12 cheminage (also called chimmage), Statutes of the Realm, n 153, vol 1, p 121. See also pedage. Riley, n 3 (Munimenta, Liber Custumarum, pt 2), p 819 'a toll due by custom for having a way through the royal forests...sometimes called 'chrminage' or 'chimmage.' Cf. OED, n 26 (toll for passing through a place or country).

${ }^{350}$ OED, n 26, quotes Chambers Cyclopedia Supplement 'sometimes denoted as a tax or duty laid on wood brought into the city.'

${ }^{351}$ Ibid, 'The right or privilege of pasturing swine in a forest. The payment made to the owner of a woodland for this right, the profit there accruing.' See also Bohun, n 1, p 36. The Carta de Foresta (1297) c 9 (see n 349) states 'Every freeman may agist his own wood within our forest at his pleasure, and shall take his pawnage.' See also Riley, n 3 (Munimenta, Liber Custumarum, pt 2), p 818. Webb's Case (1612) 8 Coke's Reports 46 (77 ER 541) at 47 (note D) 'Pannagium is properly a liberty for hogs to feed or acorns etc.' See also Seyer, n 157, p 26 and Wild Creatures and Forest Laws Act 1971, s 1(5)(preserves pannage). Also, Manwood (1741), pp 227-32 (pannage).

352 Riley, $\mathrm{n} 3$ (Munimenta, Liber Custumarum, pt 2), p 808 'Licence granted to feed cattle in the lord's woods; and in some instances, liberty to cut grass there.' Halsbury, n 1, vol 13, para 411 'Herbage' means the natural vegetation of any land as a distinct species of property; hence 'a liberty that a man has to feed his cattle in another man's ground, as in the forest' (Cowell, 1607)'(spelling modernised).

${ }^{353}$ Robertson, n 21, p 291 translates this as 'toll and fees for transit and market fees.'

${ }^{354}$ See Birch, n 3, pp 3-4. See also: (a) charter of Henry II c. 1155 ('all the citizens of London shall be quit from toll and lastage, throughout all England, and the ports of the sea...And if any in all England shall take any custom or toll of or from the men of London, after he shall fail of right the sheriff of London may take goods thereof at London.'). See Birch, n 3, p 6; (b) $1^{\text {st }}$ charter of Richard I of 23 April 1194 ('all the citizens of London shall be free from toll and lestage, throughout all England and the sea-ports... and, if any in all England shall take toll or custom of the men of London, after he shall fail of right the sheriff of London may take goods thereof at London.'). As Bateson, $\mathrm{n} 5$, vol 2, $\mathrm{p}$ lv notes, the right to take distress (ie. withernam) was transferred from the citizen to the sheriff in this charter. Also it became restricted to the goods of the offender in London and not outside; (c) charter of Edward I of 28 May 1298 ('be for ever free and quit of pannage, pontage and murage throughout all the realm, and all our dominions.'). See Birch, n 3, pp 43-4. Also, Halsbury, n 1, vol 29(2), para 1041.

${ }^{355}$ OED, n 26, 'In an action of replevin, the [requisition] of other goods in lieu of those taken by a [first] distress and eloigned; also the writ (called capias in withernam) commanding the sheriff to take the reprisal.' See generally, Bohun, n 1, pp 37-8; Robertson, n 21, p 374; Bateson, n 5, vol 1, pp 119-25; Letterbook D, n 3, p iii and Blackstone, n 2, vol 3, p 148. See also Ballard, n 5, p 195.

${ }^{356}$ (a) $1^{\text {st }}$ charter of John of 17 June 1199 ('all the citizens of London shall be quit from toll or lastage, and every other custom throughout all our lands, on this side and beyond the seas... and if any, in any of our lands on this side or beyond the seas, shall take any toll of custom for the men of London, after that he shall fail of right, may take goods therefore at London'). See Birch, n 3, pp 11-2; (b) $4^{\text {th }}$ charter of Henry III of 16 March 1227 ('all the citizens of London be quit of toll and lastage, and of all other customs throughout all our lands, on this side, or beyond the seas.' Also, 'if any shall take any toll or other custom of our men of London, in any our lands on this side, or beyond the seas, after he shall fail of right, the sheriffs of London may take goods for the same'). See Birch, n 3, pp 28-9. (c) $6^{\text {th }}$ Charter of Henry III dated 12 June 1253 ('our said citizens throughout all our dominions, as well on this side the sea as beyond, be quit of all toll and custom for ever.'). See Birch, n 3, p 35 .
} 
our grant (except the aforesaid prices) after he shall fail of right, the sheriff may take goods therefor at London. ${ }^{357}$

The reference to prises of wine refers to an ancient duty of prisage which was levied on imported wine. A $1^{\text {st }}$ charter of Edward III of 6 March 1327 provides that:

no purveyor and taker, officer and other minister of us and our heirs, or of any other, shall make any the prises in the said city, or without, of the goods of the citizens of the said city, contrary to their will and pleasure, unless immediately they make due payment for the same, or else may have respite thereof, with the goodwill of the seller. And that no prise be made of the wines of those citizens, by any the officers of us or our heirs, or otherwise against their wills; that is to say, of one tun before the mast, and another behind it, nor by any other means; but shall be quit thereof for ever. Furthermore, we forbid, that any officer of us or our heirs shall merchandise by himself or others within the said city, or without, of any thing touching their offices. ${ }^{358}$

Prisage was abolished in $1809 .{ }^{359}$ As to the exemption from tolls, in time, this was extended to many other boroughs and cities. ${ }^{360}$ Whilst this freedom from tolls might seem of great benefit to London citizens, in practice it was much more limited in scope, since:

- The exemption only applied to freemen who were resident in the City; ${ }^{361}$

- To obtain the exemption, a document (called an exemplification) had to be obtained from the town clerk, under the seal of the mayoralty, certifying the claimant to be a citizen of London ${ }^{362}$ and a certificate had to be obtained from the parish minister and churchwardens certifying that the claimant was resident. This is all long obsolete. ${ }^{363}$

- This exemption did not exempt from statutory tolls. ${ }^{364}$

Today, the above mentioned tolls are either long obsolete or have been replaced by legislation or contract. For example, the last grant of murage (such grants were limited in time, often for 7 years) was likely given in the $15^{\text {th }}$ century. In any case today, city walls are no longer erected for defensive purposes. ${ }^{365}$ Nor are goods obliged to be weighed on public scales, such as in the case of tronage or lastage. ${ }^{366}$ Other tolls were formally abolished - such as scavage - or they have become obsolete such as boscage or cheminage. Further, general (or local) legislation in Victorian times superceded Crown tolls and any franchise thereof by making made statutory provision for the paving of streets (pavage), bridge tolls (pontage) and ferries (passage) ${ }^{367}$ In 1854, Pulling mentioned only a few tolls imposed in London. ${ }^{368}$ Thus, it is asserted that, today, this liberty of being exempt from tolls is of no worth since the tolls themselves are all obsolete. Further, the mechanism for the citizens of London claiming exemption from tolls no longer exists.

\footnotetext{
357 See Birch, n 3, p 39. See also Norton, n 3, p 328.

${ }^{358}$ Birch, n 3, p 58. See also Sharpe, n 30, vol 2, p 9 and Calthrop, n 3, p 33 (who analyses the nature of prisage). See also Hargrave, n 334, pp 127-9.

35949 Geo III c 98, s 35. See also McBain, n 172, p 544. See also Riley, n 3 (Munimenta, Liber Custumarum, pt 2), p 753.

${ }^{360}$ See the texts referred to in $\mathrm{n} 5$. In particular, Weinbaum, $\mathrm{n} 5$, $\mathrm{p}$ xxix.

${ }^{361}$ Pulling, n 3, p 67. See also CMC, n 14, p 120 (in 1837, 'this privilege is not very extensively used'). See Mayor of Lynn v Mayor of London (1791) 4 TR 144 (100 ER 933) and Mayor of London v Mayor of Lynn (1796) 1 B \& P 488 (126 ER 1028). See also Norton, n 3, p 288; Jacob, $\mathrm{n} 3$, p 151 and Gunning, n 328, pp 93, 99-100. A person generally could secure a writ de essendo quietum de theolonio (writ of being quit of toll) to prove exemption. See Fitzherbert (1793), pp 503-8. However, the cases in 1791 and 1796 contain statements by Kenyon CJ and Eyre CJ that such a writ (and process) was long obsolete.

${ }^{362}$ For the form in 1680, see LL, n 3, pp 132-5.

${ }^{363}$ Pulling, n 3, p 67. See also McBain, n 4.

${ }^{364}$ Noted by Norton, n 3, p 288.

${ }^{365}$ See McBain, $\mathrm{n} 4$.

${ }^{366}$ Norton, n 3, p 378 notes that merchants in London were beginning to evade tronage as early as 1720 . By the time of Pulling (in 1854) tronage was obsolete.

${ }^{367}$ Thanks to bridges, there are very few domestic ferries which operate in England today and their charges are by statute (usually a local Act). See McBain (2005), p 590. For road and bridge tolls existing in England and Wales today, see McBain, n 4. Also, DOT (2010).

${ }^{368}$ Tolls for pickage, stallage, street tolls (payable on non freemen's goods passing in carts), groundage, water baillage (on imported corn), a duty on coal and for the metage of corn and fruits. See Pulling, n 3, pp 93-4. All of these were obsolete by 1902. For the replacement of market tolls by statutory or contractual charges see MAF, vol 1, ch 2, especially $\mathrm{p} 15$.
} 
In conclusion, this liberty is obsolete since prisage (a Crown duty on imported wine) was abolished in 1809 and tolls arising pursuant to Crown prerogative are either obsolete or the means of claiming an exemption no longer exist.

\section{Liberty - Sokes}

In Anglo-Saxon times, London was a loose association of wards, sokes and liberties. ${ }^{369}$ The 'soke' was an area in which the Crown granted a degree of independent (exclusive) criminal and civil jurisdiction to an individual or association. ${ }^{370}$ There were a number of such sokes in London. For example, in the time of Henry I (1100-35), 'sokes' in London included those of St Paul's, ${ }^{371}$ the Bishop of London ${ }^{372}$ and the Cnihtengild. ${ }^{373}$ The privilege of having a soke could be lost. ${ }^{374}$ A charter of Henry I (1100-35) of 1132 provides that:

the churches and barons and citizens shall and may peaceably and quietly have and hold their sokes with all their customs; so that the strangers that shall be lodged in the sokes shall give custom to none but to him to whom the soke appertains; or to his officer whom he shall there put. ${ }^{375}$

As Norton notes, the effect of this was that Henry I (1100-35) recognised the wards of the City and the court of wardmote (leet jurisdiction). ${ }^{376}$ Over the passage of the centuries, as the jurisdiction of the king's courts increased - together with the dissolution of the monasteries - these places of privileged jurisdiction in London disappeared, the creation of new sokes having gone by the reign of Edward III (1327-77) anyway. ${ }^{377}$ Today, no sokes exist in London. Further, courts leet no longer operated after $1977 .{ }^{378}$

Sokes no longer exist in London or generally. Thus, this liberty is obsolete.

${ }^{369}$ Noted by COL, n 3, p 6. For sokes which existed prior to 1150 (and a useful map), see Page, n 3, ch 4. See also Riley, n 3 (Munimenta, Liber Custumarum, pt 2), pp 764, 824, 826 .

${ }^{370}$ Stubbs, n 9, pp 119-20. Norton, n 3, p 289 'The soc or soke was that district in the demesne of the lord over which he possessed judicial authority, both criminal and civil.' On sokemen, see Fleta, n 144, vol 72, pp 17-8. Stenton, n 20, p 540 'There is little doubt that long before the Conquest, through the acquisition of London properties by persons of high rank, the process had begun which was ultimately to create innumerable enclaves of prívate jurisdiction in every part of the city. It is in London that the urban immunity, or 'soke', comes to its highest point of development in England. But in 1066, apart from a number of ancient estates in the hands of important churches, the prívate soke is unlikely to have been much more than an occasional exception to a judicial system which rested on public authority.' See also Ballard, n 5, p lvi who describes sokens (private jurisdictions) as a 'jurisdictional oasis'. See ibid, p 129.

${ }^{371}$ Norton, n 3, p 323 notes that the soke of St Paul's was granted by William I (1066-87) and that it had the liberties of sac and soc, tol and theam (see ns 475 and 476 for its meaning), infangthef and outfangthef. See also Little (1925) containing an article by HWC Davis, London Lands and Liberties of St Paul's 1066-1135, pp 45-55.

${ }^{372}$ Charter of Liberties of the Bishop of London of 1228. Among other things, it provided that the citizens of London granted that no sheriff (or bailiff) of London should enter the soke of the bishop of London in Cornhill to make attachment, if the plaint had not previously been shown to the bailiffs of the bishop etc. See also Riley, n 3 (Chronicles), p 210.

${ }^{373}$ They were a guild of knights who occupied land that later became part of the Portsoken, see n 137 and Letterbook C, n 3, pp xviii et seq. See also Norton, n 3, p 291 and Ballard, n 5, pp ciii-v.

374 eg. loss of the soke of Lord Fitz-Walter in London in 1347. Formerly, he was owner of Baynard's castle in the City (see Wikipedia for details of the castle). See also Riley n 3, (Memorials), pp 236-7 and Sharpe, n 30, vol 1, p 74. The sokes often were problematic, since persons fled to them after making fraudulent assurances of their lands to deceive creditors. See 50 Edw III c 6 (1376-7)(rep) re soke of Westminster.

${ }^{375}$ See Birch, n 3, p 3. Robertson, n 21, p 291 (alternative translation) 'And the churches and barons and citizens shall have and hold in peace and security their rights of jurisdiction along with all their dues, in such a way that lessees who occupy property in districts under prívate jurisdiction shall pay dues to no one except the man to whom the jurisdiction belongs, or to the official whom he has placed there.' See generally, Norton, n 3, pp 289-92. Also, Bateson, n 5, vol 1, p 2. Ballard, n 5, p ix 'These customs are not only the profits of jurisdiction, but also the rents and other dues from the inhabitants of the sokens.'

${ }^{376}$ Norton, n 3, p 59 (the former name for wards was likely gilds).

${ }^{377}$ Page, n 3, p 158 'Other sokes arose in and around London during the thirteenth century until the legislation of the Edwards brought the practice of creating them to an end.' See also Inwood, n 3, p 44 (insignificant, if not inexistent by the 13th century in the case of prívate sokes. Church ones lasted longer). It may be noted that the palatines of Chester, Durham and Lancaster were not sokes, as such, since they had a more extensive grant of Crown rights (regalem potestatem in omnibus, as Bracton put it). However, they no longer have such rights. Thus, the status of 'county palatine' no longer exists in reality. The liberties of the Cinque Ports (including any separate legal courts) have also ended. See McBain, $\mathrm{n} 4$.

${ }^{378}$ The last liberty (soke) appears to have abolished in 1825. See Inwood, n 3, p 155. For the Acts abolishing privileged places, see 8 \& 9 Will \& Mary c 27 (1697), 9 Geo I c 28 (1722) \& 11 Geo I c 22 (1724). For the ending of courts leet, see Administration of Justice Act 1977, s 23. To the extent that the Temples can be said to constitute a soke today (see $\mathrm{n}$ 6), the charter is not relevant with respect to customs (dues) existing in 1132. 


\section{Restrictions on Merchants}

The citizens of London in early times - rather like those of the city of Rome - had a suspicion not only of foreigners but also of those who were not of the City. That said, various groups of foreigners living in London acquired privileges over time. ${ }^{379}$ Furthermore, being a freeman of the City brought benefits to merchants. As a commentator noted:

The freedom of the city of London was no empty honour. Without it a man was not at liberty to open a shop, to traffic by retail, or even to reside within the City's walls, except for a limited time, and then only in the houses of freemen and under frankpledge. ${ }^{380}$ On the other hand, a man who had acquired the freedom by any one of the three methods just mentioned ${ }^{381}$ was free to trade by wholesale or retail with fellow citizen or stranger, to carry his goods throughout the length and breadth of the land, and to enter any town without payment of murage or other toll. ${ }^{382}$

There were also other restrictions imposed on merchants:

(a) Forestalling. This was the crime of: (i) buying of goods on the way to market and, thereby, raising the price; or (ii) dissuading sellers from bringing their goods to market; or (iii) persuading the sellers of goods to enhance the price when at market. ${ }^{383}$ An 8th charter of Henry III of 26 March 1268 makes provision against it. ${ }^{384}$ The offence of forestalling was abolished in $1844 ;{ }^{385}$

(b) Weighing Goods on the King's Beam. As previously indicated (see 8.2), to prevent the selling of goods at underweight, from early times, there was established in London the king's beam (or tron). An 8th charter of Henry III of 26 March 1268 provides that no merchant stranger (or other) may buy, or sell, any wares, which ought to be weighed or troned, unless by the king's beam - on forfeiture of the said wares. ${ }^{386}$ The Constitutions of Edward II of 8 June 1319 provides that the weights and scales of merchandises to be weighed between merchants and merchants should remain in the 'custody of honest and sufficient men' of the city. ${ }^{387}$ The king's beam - and tronage - have long been obsolete;

(c) Freedom of the City. The Constitutions of Edward II of 8 June 1319 stipulates that no stranger be admitted to the freedom of the City in any husting (and that no member of any mystery (guild) or trade be admitted) without the surety of 6 men. ${ }^{388}$ And that merchants not of the freedom of the City are prohibited from

\footnotetext{
379 eg. Gascon wine merchants claimed exemption from murage and pontage, see Letterbook D, n 3, p iii. The Merchants of Almaine (Hanseatic traders) also had privileges in London. See also Gomme, n 3, pp 333-4, Riley, n 3, (Memorials), p 57, Riley, n 3, (Munimenta, Liber Custumarum, pt 1), p xxxiv et seq.

${ }^{380}$ Walker, n 27 (frankpledge). 'A system in Norman England, replacing the local responsibility of the tithing, or group of ten men, for producing an offender, whereby each freeman over 12 years of age had to be enrolled in a friborh, or frankpledge, or tenmannetale, an association of ten men who formed collective bail for the appearance of any one of them before a court, when necessary.' Views (courts) of frankpledge no longer operate subsequent to the Administration of Justice Act 1977, s 23. See also The Mirror of Justices, vol 7, p 39.

${ }^{381}$ ie. (1) by birth, otherwise patrimony; (2) by apprenticeship or servitude; (3) by payment of a sum of money, otherwise known as redemption.

${ }^{382}$ Letterbook D, n 3, p ii. For admitting foreigners to the freedom of the city, see p v et seq (including the Regulations of 1319).

383 See 5 \& 6 Edw VI c 14 (1551, rep). See also Blackstone, n 2, vol 4, p 158.

384 'no merchant or other do meet any merchants coming by land or by water, with their merchandise or victuals, towards the city, to buy or sell again, till they come to the said city; and there have put the same to sale, upon the forfeiture of the things brought, and pain of imprisonment; from whence he shall not escape without great punishment: and that none show out their wares to sell, who owe any custom, until the custom thereof be levied, without great punishment, and upon pain or forfeiture of all that commodity of him that happens to do otherwise.' See Birch, n 3, pp 40-1.

3857 \& 8 Vict c 24 (1844). See also Bacon, n 11, vol 2, p 246.

386 'no merchant stranger or other, may buy or sell any wares, which ought to be weighed or troned, unless by our beams or trone, upon forfeiture of the said wares.' See Birch, n 3, p 41.

387 'That weights and scales of merchandises to be weighed between merchants and merchants, the issues coming of which belong to the commonality of the said city, remain in the custody of honest and sufficient men of the same city, expert in that office, and as yet to be chosen by the commonality, to be kept at the will of the same commonalty; and that they be by no means committed to others than those so to be chosen.' See Birch, n 3, p 48.

388 'That no stranger be admitted into the freedom of the city in the husting; and that no inhabitant, and especially English merchant, of any mystery or trade, be admitted into the freedom of the city, unless by surety of [6] honest and sufficient men of the mystery or trade that he shall be of, who is so to be admitted into the freedom; which [6] men may undertake for him, of keeping the city indemnified in that behalf. And that the same form of surety be observed of strangers to be admitted into the freedom in the husting, if they be of any certain mystery or trade. And if they are not of some certain mystery, then that they be not admitted into the freedom without the assent of the commonality. And that they who have been taken into the freedom of the city (since we undertook the government of the realm) contrary to the forms prescribed, and they
} 
selling wines and other wares by retail. ${ }^{389} \mathrm{~A} 1^{\text {st }}$ charter of Charles I of 18 October 1638 provides that women of freemen are empowered to use manual arts and occupations even though they have not served the 7 years required for apprentices ${ }^{390}$ and the same charter obliges merchants in the City, and within 10 miles thereof, to take up their freedom. ${ }^{391}$ All these restrictions have long ended; that on selling by retail by an Act of Common Council, for example, in $1856 ;{ }^{392}$

(d) Merchant Strangers. The citizens of London had an innate suspicion and dislike of foreigners, often seeking to be rid of them or severely restricting their rights within the City. ${ }^{393}$ An 8th charter of Henry III of 26 March 1268 provides that no merchant stranger or other may buy (or sell) any wares, which ought to be weighed or troned, unless by the king's beam - on forfeiture of the said wares (see also (b)) ${ }^{394} \mathrm{~A} 1^{\text {st }}$ charter of Edward III of 6 March 1327 provides that merchant strangers to the City must sell their wares within 40 days $^{395}$ and that they must reside with freemen (possibly, it means with common innkeepers) when in London. ${ }^{396}$ Finally, regulations concerning strangers buying, and selling, within the City contained in a charter of Henry VII of 22 August 1485 provides that merchant strangers cannot sell to

who have gone contrary to their oath in this behalf, or contrary to the state of the city, and are thereof lawfully convicted, lose the freedom of the said city. Saving always, that concerning apprentices the ancient manner and form of the said city be observed.' See Birch, n 3, pp 46-7. Freeman exercising (claiming) goods not of freemen (to get benefit thereby) would lose their status, ibid, p 47. See also Inwood, n $3, \mathrm{p} 72$.

389 'Merchants who are not of the freedom of the city, not to sell, by retail, wines or other wares, within the city or the suburbs.' See Birch, $n$ 3, p 48. Also, $6^{\text {th }}$ charter of Edward III of 4 November 1376 'the merchants who are not of the freedom of the said city, should not sell by retail any wines or other wares within the said city, or the suburbs thereof.' See Birch, n 3, p 67. See also a charter of Richard II (1377-99) of unknown date cited by Birch, n 3, p 70 (foreign merchants not to trade in London among themselves). See also Bohun, n 1, pp 159-73. An Act of Common Council of 18 December 1856 abolished all laws and customs which prohibited persons other than freemen from carrying on business by retail in the City. See RC, n 14, vol 18, p 191.

390 'the relicts and widows of freemen of the said city, using manual arts and occupations, so long as they shall continue widows, and remain in the same city...may and be licensed to use and execute, and exercise the same arts and manual occupations in the said city although they were not educated by the space of [7] years as apprentices.' See Birch, n 3, p 186. The charter also provides that no merchant may take an apprentice for less than 7 years, see Birch, n 3, pp 189-90. The system of apprenticeship may have been introduced in London in 1275, see Letterbook D, $\mathrm{n} 3$, p viii.

391 'all they who are, or hereafter shall be sons of freemen of the city, or who are, or hereafter shall be apprentices, or servants of freemen of our said city, and now do, or hereafter shall reside, or inhabit in the same city, or the liberties of the same, or within [10] miles distant from any part of the same, and do, or shall use merchandise, and who do, or shall refuse, or delay to become freemen of the said city, shall not be permitted at any time henceforth, by themselves or by others, directly or indirectly, to transport any goods, wares, or merchandises, by way of merchandising in any way, from the port of our city of London, to parts foreign, or beyond the seas.'. See Birch, n 3, pp 188-9.

${ }^{392}$ See Norton, n 3, p 196. Cf. Municipal Corporations Act 1835 s 14 (rep) 'every person in any borough may keep any shop for the sale of all lawful wares and merchandises by wholesale or retail, and use every lawful trade, occupation, mystery, and handicraft, for hire, gain, sale, or otherwise, within any borough.' Gross (1967), vol 1, p 6.

${ }^{393}$ Letterbook C, n 3, p iii \& ix-x. Foreign merchants could claim admittance to the franchise but only on condition they bore tallage and other charges imposed on the city. Ibid, pp ix-xiii. McKechnie, n 15, p 405 'The merchant stranger had to take up his abode in the house of a citizen. He was prohibited from purchasing articles in process of manufacture. He could buy only from those who had the freedom of the city, and could not re-sell within the borough walls. He was allowed to sell only to burgesses of London, except on three specified days of the week.' See also Norton (1821).

394 'no merchant stranger or other, may buy or sell any wares, which ought to be weighed or troned, unless by our beams or trone, upon forfeiture of the said wares.' See Birch, n 3, p 41. The tron is obsolete, see n 231.

395 'all merchant strangers, coming to England, shall sell their wares and merchandises within [40] days after their coming thither.' See Birch, n 3, pp 54-5 and Norton, n 393, p 11.

396 'and shall continue and board with free hosts of the said city, and other cities and towns in England, without any households or societies by them to be kept.' See Birch, n 3, pp 54-5. Also Riley, n 3 (Chronicles), pp 123-4 (foreigners fined in 1269 for not doing so). See also $6^{\text {th }}$ charter of Edward III of 4 November 1376 'all merchant strangers coming into England, shall remain at board with the free hosts of the city aforesaid, and of other cities and towns in England, without keeping any houses or societies by themselves.' See Birch, n 3, p 67. Also, Thomas, n 21 , p 9. 
other merchant strangers in the City. ${ }^{397}$ These restrictions were ameliorated by an Act of Common Council in 1750 which licensed foreigners to work in the City ${ }^{398}$ and are now long obsolete;

(e) Brokers. The Constitutions of Edward III of 8 June 1319 restricts brokers of merchandise in the City - 399 brokers being those who acted as intermediaries in the sale of goods. ${ }^{400}$ The admission, and regulation, of brokers was abolished by the London Brokers Relief Acts 1870 and 1884. ${ }^{401}$ Thus, the provisions of this charter are obsolete;

(f) Court of Piepowder. A $1^{\text {st }}$ charter of Edward III of 6 March 1327 provides that the citizens of London have power to hold courts of piepowder (pie poudre) at fairs within the City. ${ }^{402}$ Courts of piepowder disappeared by the $17^{\text {th }}$ century and they were finally abolished in $1977 ;{ }^{403}$

(g) Markets and Market Overt. ${ }^{404}$ A $1^{\text {st }}$ charter of Edward III of 6 March 1327 provides that no market be kept within 7 miles of the City. ${ }^{405}$ However, this prohibition was not observed and is not of relevance today since there are no open markets within the City. ${ }^{406} \mathrm{~A} 3^{\text {rd }}$ charter of Edward III of 26 March 1337 refers to the Statute of York (1335) ${ }^{407}$ and indicates that it does not override the liberties and free customs of the citizens of London. ${ }^{408}$ The Statute of York was repealed in $1863 .{ }^{409}$ In respect of market overt, by

\footnotetext{
397 'no stranger from the liberties of the same city may buy or sell from any other stranger to the liberty of the same city, any merchandise or wares within the liberties of the same city.' If so, the goods were forfeit to the mayor. See Birch, n 3, p 95. A common trick to avoid this was for merchant strangers to have freemen 'colour' their goods (ie. claim them as their own). A freeman convicted of this would lose his freedom of the city, see Letterbook D, n 3, pp iii \& 238. See also City of London's Case (1610) 8 Coke's Reports 126 (77 ER 658) (City custom that no foreigner shall keep any shop, or use any trade, in London).

${ }^{398}$ See Birch, n 3, pp 305-6.

399 'That there be no brokers hereafter in the city of any merchandises, unless elected to this by merchants of the mysteries [trades] in which the brokers themselves may have to exercise their offices; and at least of this to make oath before the mayor.' See Birch, n 3, p 49. See also $6^{\text {th }}$ charter of Edward III of 4 November 1376 'there shall be no brokers of any merchandises from henceforth, unless they were chosen thereunto by the merchants in the mysteries in which the said brokers exercise their offices, and thereupon at the least do take their oaths before the mayor of the said city.' See Birch, n 3, p 67. The Statutes of the City of London (Statuta Civitatis London) 13 Edw 1 (1285) provided that 'There shall be no broker in the City, except those who are admitted and sworn before the warden or mayor, and alderman.' See SR, n 153, p 103.

${ }^{400}$ For their oath, see Letterbook D, n 3, p 9 and for their regulations, ibid, pp 219-20.

${ }^{401}$ RC, n 14, vol 18, p 379. See generally, Pulling, n 3, ch 24.

402 'And forasmuch as the citizens, in all good fairs of England, were wont to have among themselves keepers to hold the pleas touching the citizens of the said city assembling at such fairs: We will and grant, as much as in us is, that the same citizens may have such-like keepers, to hold such pleas of their covenants, as of ancient time they had, except the pleas of land and of the crown.' See Birch, n 3, p 55. Also, Walker, $n$ 27 (fairs and boroughs).

${ }^{403}$ Administration of Justice Act 1977, s 23. It is said the last piepowder court was held in 1898 at Hemel Hempstead.

${ }^{404}$ It may be noted that the City regulated the markets within it. By 1854, the main ones were Leadenhall, Milkstreet, Newgate, Billingsgate and Smithfield. Today, Leadenhall market (in Gracechurch Street) - which was a poultry market started in 1309 - is a shopping arcade and Milkstreet comprises offices and shops. Newgate market (a dead meat market) no longer exists, being transferred to Smithfield in 1868. Billingsgate market, once located in a ward on the south east of the City, has moved to East London. Finally, Smithfield (a meat market, started in 1150 and which was outside the City walls) was closed in 1855 and now is situated in the north of Islington. The City runs Smithfield and Leadenhall markets and owns Billingsgate and Spitalfields markets. They have all long been regulated by Acts. See also Owen, $\mathrm{n} 14$, pp 244-6; COL, n 3, p 134 et seq and Sharpe, n 30, vol 2, pp 433-4. In the time of Elizabeth I (1558-1603) the four main London markets were Smithfield, Newgate, Leadenhall and the stocks market by the Mansion house. In the 17th century the Crown and City licenced the following markets: Clare (1653), Stepney (1664), Honey Lane (1667), Fleet (1700), Woods Close (1706), Hungerford (1749) and Southwark (1735).

405 'no market from henceforth shall be granted by us or our heirs, to any within [7] miles in circuit of the city.' See Birch, $n 3$, p 58. See also $1^{\text {st }}$ charter of Charles I of 18 October 1638 'no market shall from henceforth be granted, erected, or permitted by us...within [7] miles compass of the said city.' See Birch, n 3, p 186 and Islington Market Bill (1825) 3 Cl \& Fin 513 (6 ER 1530). Under the common law, no market could be erected so as to be a nuisance to another market within a less distance then 6 miles and a half and a third of another half. See Sharpe, $\mathrm{n} 30$, $\mathrm{p} 161$ referring to Bracton (1968-76), vol 3, p 187. See also RC, n 14, vol 18, p 79 and, generally, Hallett (2009), ch 6.

406 eg, Covent Garden and Spitalfields were granted in derogation of the City's rights. See COL, n 3, p 135. These markets were granted by Charles I (1660-85) to individuals. See RC, n 14, vol 18, p 3. Covent Garden (a fruit and vegetable market which started in 1670) was moved south of the Thames in 1974. Today, the old market comprises shops. See also Owen, n 14, p 228 and Hallett, n 405 , ch 6.

4079 Edw III st 1. See also Pulling, n 3, pp 382-3; Sharpe, n 30, p 181 and Norton, n 3, pp 363-4.

408 'we have granted, for us and our heirs, that the citizens of the said city, their heirs and successors, may have all their liberties and free customs unhurt and whole, as before these times they more fully had the same; the foresaid statute for the said merchants, made to the hurt of the liberties and customs of the said city, notwithstanding.'. See Birch, n 3, p 62 and Anon, n 3, p 15.
} 
custom, every shop in the City in which goods were publicly exposed for sale was a market overt for goods professedly dealt in there. ${ }^{410}$ Market overt was abolished by the Sale of Goods (Amendment) Act 1994;

(h) Right to Granage. Also called carnage. Bohun (in 1723) said it was a custom of London that the mayor had a right to a $20^{\text {th }}$ part of all salt brought into the port of London by foreigners. ${ }^{411}$ This is obsolete - not least since the Port of London is not part of the Square Mile;

(i) Purveyance. The seizure of citizen's goods for the king's household is forbidden by a $1^{\text {st }}$ charter of Edward III of 6 March 1327. ${ }^{412}$ Purveyance was abolished by the Tenures Abolition Act 1660. ${ }^{413}$

In conclusion, all these restrictions on merchants are now obsolete. Purveyance, courts of piepowder and market overt has been abolished.

\section{Liberties - Escheat, Waifs, Estrays and Treasure}

\section{A $1^{\text {st }}$ charter of Charles I of 18 October 1638 provides that:}

We...do give and grant to the said mayor and commonalty and citizens...all treasure found in the same city, or the liberty of the same, and also waifed and strayed goods and chattels of all felons and fugitives, for felonies committed, or that shall be committed by them in the said city, or the liberties of the same. ${ }^{414}$

- The Crown has the prerogative (ie. the right) to stolen goods cast away by a thief in flight. This right it could franchise, as here, to the City. ${ }^{415}$ It has been argued, in another article, this prerogative is obsolete and not required. ${ }^{416}$ Further, in the case of the Square Mile, it is hardly likely such an event will now occur since there is a police force to apprehend thieves and recover stolen goods; ${ }^{417}$

- The Crown also has a prerogative to strays animals of a tame (or reclaimable) nature found wandering in any manor or lordship whose owner is unknown. ${ }^{418}$ It has been argued, in another article, this prerogative is obsolete and not required. ${ }^{419}$ Further, it is hardly likely in the Square Mile;

- The reference in the charter to escheat in respect of the chattels of felons is obsolete since forfeiture of the goods of felons was abolished by the Forfeiture Act 1870 and, indeed, felony no longer exists; ${ }^{420}$

\footnotetext{
409 Statute Law Repeals Act 1863.

${ }^{410}$ Bohun, n 1, pp 204-5; Jacob, n 3, p 104-7; Halsbury, n 1, vol 12(1), para 628 n 14; Blackstone, n 2, vol 2, pp 449-50, Bateson, n 3, vol 2, p lxxviii.

${ }^{411}$ See Bohun, n 1, p 79; Jacob, n 3, p 125 and Pulling, n 3, p 398. Also, 3 Dyer 352 (73 ER 791)(a custom called cranage).

412 'no purveyor and taker,officer and other minister of us and our heirs, or any other, shall make any prices in the said city, or without, of the goods of the citizens of the said city, contrary to their will and pleasure, unless they immediately make due payment for the same, or else may have respite thereof, with the goodwill of the seller. And that no price [prise] be made of the wines of those citizens, by any of the officers of us or our heirs, or otherwise against their wills; that is to say, of one tun before the mast, and another behind it, nor by any other means; but shall be quit thereof for ever. Furthermore, we forbid that any officer of us or our heirs shall merchandise by himself or others within the said city, or without, of any thing touching their offices.' See Birch, n 3, pp 55-6. Also, Letterbook D, n 3, p xxiii.

${ }^{413}$ McBain, n 172, p 541.

${ }^{414}$ Birch, $n 3, p$ 187. A $2^{\text {nd }}$ charter of James I of 20 September 1608 provides that 'the said mayor and commonalty and citizens of the said city of London...may have and enjoy to their proper use, without any account thereof to be rendered to us...all treasure found, or to be found in the said franchises and places called Blackfriars, Whitefriars, Duke's Place, Great St Bartholomew's, Little St Bartholomew's, and Cold Harbour aforesaid, and waived goods and chattels, and estrays, goods and chattels of felons and fugitives, from whatsoever felony done or to be done by them, within any of the said franchises or places ajudged or to be adjudged before us, our heirs and successors, or any of our justices.' See Birch, n 3, p 149 and Norton, n 3, p 396. For escheats and strays in Southwark, see n 289.

${ }^{415}$ Halsbury, n 1, vol 12(1), para 371. 'Waifs are things stolen and thrown away by the thief in his flight; and they belong to the crown by prerogative right, as a punishment, it is said, to the owner for not having pursued the thief and retaken the goods.'

${ }^{416}$ McBain, $\mathrm{n}$ 4. The caselaw is exceedingly old, the last case probably being Foxley's Case (1600) 5 Co Rep (77 ER 224).

417 The right of forfeiture to the Crown did not apply anyway to: (a) goods retaken by the owner prior to seizure by the Crown; (b) where the owner of the goods pursued the thief with due diligence (this is called 'fresh suit'); (c) if the stolen goods were hidden or left behind; (d) the goods of a foreign merchant. See McBain, $\mathrm{n} 4$.

${ }^{418}$ Halsbury, n 1, vol 12(1), para 372 'Estrays are valuable animals of a tame or reclaimable nature which are found wandering in any manor or lordship, and whose owner is unknown. They belong to the monarch as general owner and lord paramount by way of recompense for the damage done, and to preserve the animal alive, unless, as is more generally the case today, they belong to the lord of the manor by grant or prescription.'

${ }^{419}$ McBain, $\mathrm{n} 4$.

${ }^{420}$ Criminal Law Act 1967, s 1 .
} 
- Treasure was another Crown prerogative which could be franchised. The law on it is now contained in the Treasure Act 1996. The right of the City to treasure would not only apply to the Square Mile and treasure there is, perhaps, rather unlikely - not least since this area is deep with skyscrapers. It is asserted this franchise could be given up, leaving the matter to be determined by the general law.

In conclusion, the liberty in respect of the goods of felons has been abolished and those in respect of waifs and strays are obsolete (and not unlikely to occur in the Square Mile in any case). Further, the liberty in respect of treasure only applies to the Square Mile and it could be given up without much hardship.

\section{Liberties - Amercements, Lands, Promises, Debts \& Wills ${ }^{421}$}

The charters to the citizens of London grant various liberties in respect of: amercements, lands, wills, promises and debts. Essentially, the major ones are that: (a) citizens of London are only to be fined up to a maximum sum of $100 \mathrm{~s}$ by way of amercement; (b) all pleas in respect of the lands, promises, bond and debts of the citizens of London are to held within the City (this is connected with the right to be tried 'within the walls' (see 5)); (c) citizens may devise their property freely; (d) debtors to London citizens must discharge their debts in London and the citizens of London have a right of withernam (see 13) on a failure to pay. Thus, a charter of Henry I (1100-35) of c. 1132 provides:

a man of London shall not be adjudged in amercements of money but of [100s] (I speak of pleas which appertain to money)... And I will cause my citizens to have their lands, promises, bonds and debts, within the city and without; and I will do them right by the law of the city, of the lands of which they shall complain to me... ${ }^{422}$

And all debtors, who do owe debts to the citizens of London, shall pay them in London, or else discharge themselves in London, that they owe none; but if they will not pay the same, neither come to clear themselves that they owe none, the citizens of London, to whom the debts shall be due, may take their goods in the city of London, of the borough or town, or of the county wherein he remains who shall owe the debt. ${ }^{423}$ (wording divided for ease of reference).

In respect of these:

(a) Amercements. This liberty in respect of the maximum level of amercement that might be levied on London citizens was mentioned in other charters as well as in that of Henry I (1100-35) of c.1132. ${ }^{424}$ The reference to 100s [£5] was to a man's wer (wergild) in Anglo-Saxon times, being the compensation due to the kin of a slain man from the one who had slain him. ${ }^{425}$ The precise sum depended on the social status of the person slain. The wer of a citizen of London was greater than that of an Anglo-Saxon freeman (ceorl) but less than that of a thegn. ${ }^{426}$ Both wergild and amercements are long obsolete; ${ }^{427}$

(b) Lands. Mention is made in other charters besides that of Henry I of 1132 of the liberty of the citizens of London to have pleas relating to their lands litigated in London ${ }^{428}$ and Bohun (writing in 1723) records

421 See generally Bateson, n 5. Also, Riley, n 3 (Munimenta).

422 Robertson, n 21, p 291 (alternative translation) 'And a citizen of London shall not be sentenced to forfeiture of a sum greater than his wergild, namely [100s], that is to say in a case concerned with monetary compensation... And I assure to my citizens their lands and the property mortgaged to them and the debts due to them both within the city and outside. And with regard to lands about which they have appealed to me, I shall maintain justice on their behalf, according to the law of the city.'

${ }^{423}$ Birch, n 3, p 4. Robertson, n 21, pp 291-3 (alternative trans) 'And all those who owe debts to citizens shall pay them or shall clear themselves in London from the charge of being in debt to them. But if they have refused to pay or to come to clear themselves, then the citizens to whem they are in debt shall seize their pledges [and bring them] into the city from the [town, village or] county in which the debtor lives.'

424 (a) charter of Henry II of c 1155 ('none shall be adjudged for amerciaments of money, but according to the law of the city, which they had in the time of [Henry I]'). See Birch, n 3, p 5; (b) $1^{\text {st }}$ charter of Richard I of 23 April 1194 ('none be adjudged of amerciaments of money, but according to the law of the city, which they had in the time of [Henry I].'). See Birch, n 3, p 7; (c) $1^{\text {st }}$ charter of John of 17 June 1199 ('none shall be adjudged for amerciaments of money but according to the law of the city, which they had in the time of [Henry I]').See Birch, $\mathrm{n} 3$, $\mathrm{p} 11$; ( $\mathrm{d}$ ) $4^{\text {th }}$ charter of Henry III of 16 March 1227 ('none be condemned of any amerciaments of money, but according to the law of the city, which they had in the time of [Henry I].' See Birch, n 3, p 28. Also, Norton, n 3, pp 292-4.

${ }^{425}$ See Walker, n 27 (wergild).

${ }^{426}$ See Bohun, n 1, p 2; Fleta, n 144, pp 105-9; Walker, n 27 (amercement).

${ }^{427}$ Norton, n 3, p 294 (in 1869) 'practice of levying [amercements] has long ceased.'

428 (a) charter of Henry II of c 1155 ('they justly have their lands and tenures and premises, and all their debts, whosoever do owe them: And that right be done to them, according to the custom of the city, of all their lands and tenures which be in the city, and of all their debts, which were lent at London.'). See Birch, n 3, pp 5-6; (b) $1^{\text {st }}$ charter of Richard I of 23 April 1194 ('and they justly have all their lands and tenures and promises, and all other their debts, whoseoever do owe them to them; and that right be done to them, according to the custom of the city, 
the following customs of London that arose vis-a-vis land: ${ }^{429}$ (a) lands could be sold, by way of bargain and sale, by parol $;{ }^{430}$ (b) actions concerning City lands were pleadable in the court of Hustings; ${ }^{431}$ (c) no writ of lands in London lay, apart from in London, ${ }^{432}$ (d) there was a right to recover unpaid rent if the lessee was a fugitive or felon; ${ }^{433}$ (e) there were customs in respect of waste and fire in houses; ${ }^{434}$ (f) there was a custom in respect of ruinous houses; ${ }^{435}(\mathrm{~g})$ a house could be rebuilt on the old foundation where the old house stood at the same height even through, by re-building, the lights of one's neighbour were stopped up - providing there was no agreement to the contrary; ${ }^{436}$ (h) ladders (or poles) could be put on (or against) adjoining houses for repairing a man's own but not to break ground; this was warranted by the necessity of it; ${ }^{437}$ (i) a tenant at will under 40 s could not be turned out without 3 months warning (or 6 months, if more than 40s). ${ }^{438}$ All these are now obsolete or unnecessary; ${ }^{439}$

(c) Promises and Debts. Mention is made of the liberty of citizens to have matters in respect of their debts, bonds and promises litigated in London in subsequent charters as well as in that of Henry I of 1132. ${ }^{440}$

of all their lands and tenures, which they have within the city; and of all their debts which shall be lent at London, and of promises there made'). See Birch, n 3, p 8; (c) $1^{\text {st }}$ charter of John of 17 June 1199, (' they justly have their lands, and tenures, and promises, and all other debts, whosoever owe them: And that right be holden to them of their lands and tenures, which be within the city, according to the custom of the said city; and all of their debts which shall be lent at London; and that pleas of all promises there made be holden at London.'). See Birch, n 3, pp 11-2; (d) $4^{\text {th }}$ charter of Henry III of 16 March 1227 ('they may justly have all their lands and promises, and debts whosoever owe them to them; and that right be holden to them of all their lands and tenures, which be in the city, according to the custom of the city; and that pleas be there holden of all debts which be lent at London, of all promises there made.' See Birch, n 3, p 29; (e) $8^{\text {th }}$ charter of Henry III of 26 March 1268 ('right be holden to them for their lands and tenures within the same city; according to the custom of the said city so as nevertheless, that as well foreigners as others may make their attorneys, as well in pleading as defending, as elsewhere in our courts......and of all their debts which were lent at London, and promises there made, pleas be there holden, according to the just and ancient custom..' Also, 'that the said citizens may justly have and hold their lands, tenures or promises; and also their debts, whosoever do owe them.'). See Birch, $n$ $3, \mathrm{p} 40$.

${ }^{429}$ Bohun, n 1, pp 71-5.

${ }^{430}$ Ibid, p 72. Also, that the same did not have to be inrolled for title to pass, as required by 27 Hen VIII c 16 (1535) (rep)(the enrolment of bargains of lands). Also, that if a man and a wife passed the wife's lands in London by parol and she was examined outside London on the same, the custom of London bound. See also Coke, n 12, vol 2, p 675.

${ }^{431}$ Ibid, p 72 quoting Coke, n 12, vol 4, p 147.

${ }^{432}$ Ibid, p 73. See also Coke, n 12, vol 4, p 247.

${ }^{433}$ Ibid, $\mathrm{p} 75$. The landlord was entitled to be paid 2 years rent out of the goods found in the tenant's house, prior to all other debts save to those owed to the king. See also Jacob, n 3, p 98.

${ }^{434}$ Ibid, pp 76-7 'It is said to be a custom of the city that those which have tenements within the said city, shall not be suffered to strip or waste their tenements in demesne, nor to pull them down in deforming or defacing of the said city unless it be to amend them, or build them up again; and that any that doth it, or beginneth to do it, shall be punished by the mayor and aldermen for the offence.' Also, 'if any house be found within the said city, or the suburbs... covered with straw, reed or thatch, he to whom the house belongeth, shall pay to the sheriffs for the time being [40s], and shall be compelled to take away the same covering.' Also, 'if any house within the said city be burning so that the flame of the fire be seen out of the house, he that dwelleth in the said house shall pay to the sheriffs [40s] in a red purse.' See also Jacob, n 3, p 98; Calthrop, n 3 , p 122; Letterbook C, n 3, pp 105-6 and Bateson, n 5, vol 1, p 279.

${ }^{435} \mathrm{Ibid}, \mathrm{p}$ 76. If not repaired, it was repaired at the cost of City with distress being levied on householder's goods to compensate. By 1894, the Commissioners of Sewers and London County Council had powers in respect of dangerous buildings, see RC, n 14, vol 17, p 10.

${ }^{436}$ Jacob, n 3 pp 29-30 (indicating exceptions). Cf. Robins v Barnes (1613) Hobart's Reports 131 (80 ER 280)(not lawful to erect a new house on a void piece of land whereby the old lights of an ancient house may be estopped). Halsbury, n 1, vol 12(1), para 268 notes that this custom was partly abrogated by the Prescription Act $1832 \mathrm{~s} 3$. However, it was thought it might still operate to prevent a claim being set up on the basis of a lost grant - although it noted a similar York custom was rejected on demurrer in Moseley v Ball (1587) KB 27/1302, 253 cited in William Aldred's Case (1611) 9 Co Rep 76 (77 ER 816). See also Comyns, n 11, vol 5, p 23 and Calthrop, n 3, p 1.

${ }^{437}$ Bohun, $\mathrm{n} 1, \mathrm{p} 75$ and Jacob, n 3, p 30.

${ }^{438}$ Anon, n 3, p 55; Bohun, n 1, p 76; Bateson, n 5, vol 1, p 311 and Bacon, n 11, vol 2, p 258. See also Dethik v Saunders 2 Sid 20 (82 ER 1233).

439 (a) Selling land by bargain and sale ended in 1925; (b) \& (c) the court of Hustings no longer operates, see 4; (d) felony and outlawry have been abolished; (e) \& (h) houses in the City are no longer of straw and wood (brick built houses started from the time of James I (1603-25), see Norton, n 3, p 64). Further, house building today is subject to general building regulations; (f), (g) \& (i) the general law now applies, as well as contract.

${ }^{440}$ An $8^{\text {th }}$ Charter of Henry III of 26 March 1268 provides for the enrolment of debts owed to London citizens in the Exchequer ('those debts, which of their contracts or loans shall be due unto them, they may cause to be enrolled in our exchequer, for the more surety of them, upon 
Bohun (writing in 1723) records the following customs of London that arose vis-a-vis debts and promises: ${ }^{411}$ (a) actions for breach of covenant were maintainable without specialty; ${ }^{442}$ (b) beasts destrained (or goods taken) in London could not be replevied by a writ out of chancery but by the sheriffs of London; ${ }^{443}$ (c) an action of debt lay against sureties without writing (ie. by parol); ${ }^{444}$ (d) an action of debt was maintainable on a simple contract and a debt on a simple contract was equal to an obligation; ${ }^{445}$ (e) restrictions on waging one's law; ${ }^{446}$ (f) a man might maintain actions of debt sur concessit solvere; ${ }^{447}$ (g) a custom that - when a person was impleaded before the sheriffs - on the suggestion of the defendant, the mayor might send for the parties and examine them on their pleas. If he found the plaintiff was satisfied, the mayor might award that the plaintiff should be barred; ${ }^{448}$ (h) if the debtor was a fugitive he could be arrested before the day generally appointed in order to find better security; ${ }^{449}$ (i) if an obligor paid the whole debt, he had the debt pro rata against his companion; ${ }^{450}$ (j) no attaint should be brought other than in the City in respect of a false oath made there; ${ }^{451}(\mathrm{k})$ citizens should not be empanelled on inquests out of the City; ${ }^{452}$ (1) an action of debt could be maintained against executors on a simple contract; ${ }^{453}(\mathrm{~m})$ the goods (and money) of a defendant could be attached if either in the defendant's hands or in the custody of a third person (so called, 'foreign attachment' or garnishment). ${ }^{454}$ All these are obsolete or unnecessary. ${ }^{455}$

As well as these liberties there were some in relation to wills, viz.

(d) Wills. From Anglo-Saxon times, by custom, London citizens had the freedom to devise their property within the liberty of the City, as they wished. ${ }^{456}$ This freedom now applies generally. Also, for their wills

the recognizance of those who shall stand bound unto them in the said debts; so as nevertheless that no debts be enrolled upon the recognizance of any person who is not there known; or unless it be manifested concerning his person by the testimony of six or four lawful men, who be sufficient to answer as well for the debt, as for the damages which any may have of such recognizances, if the same happen to be falsely done under their names.'). See Birch, n 3, p 41. Also, Jacob, n 3, p 147. As Norton, n 3, p 331 notes, common law recognizances 'almost grew immediately after the passing this charter into general disuse.' The process of enrolling debts in the exchequer is long obsolete and barons of the exchequer are obsolete, see $\mathrm{n} 83$.

${ }^{441}$ See Birch, n 3, pp 75-9, 81-2.

${ }_{442}$ Bohun, n 1, p 77. See also Bateson, n 5, vol 1, p 211.

${ }^{443}$ Ibid, p 77. Also, Jacob, n 3, p 73 \& 138-9.

${ }^{444}$ Ibid, p 77. Also, Jacob, n 3, p 129.

${ }_{445}$ Bohun, n 1, p 77. See also Bacon, n 11, vol 2, p 258 and Day v Savadge (1614) Hobart 86 (80 ER 235).

${ }^{446} \mathrm{eg}$. in a debt for tabling the defendant was not able to wager his law, one could not wage one's law against a merchant's book and that, if the plaintiff in a debt on a contract produced two men in front of the mayor and swore the debt was true and real, the defendant was prevented from waging his law. See Bohun, n 1, pp 77-8.

${ }_{447}$ Bohun, n 1, p 78. See also Day v Savadge (1614) Hobart 86 (80 ER 235) and Viner, n 11, vol 7, p 246.

448 Ibid.

${ }^{449}$ Bohun, n 1, p 79. See also Jacob, n 3, p 70; Bacon, n 11, vol 2, p 458 and 8 Coke's Reports 126 (77 ER 664).

${ }^{450}$ Ibid. See also Jacob, n 3, p 70 and D’Anvers, n 11, vol 2, p 310. See also Riley, n 3 (Munimenta, Liber Albus III), p 40.

${ }^{451}$ Pulling, n 3, p 175, 'The ancient proceeding of attaint to reverse a verdict given in any of the other courts, might also be taken in the hustings; but this proceeding is now universally abolished.' See 6 Geo IV c 50, s 60 (1826). See also Calthrop, n 3, p 116 and Bacon, n 11, vol $2, \mathrm{p} 246$.

${ }^{452}$ Bohun, n 1, p 79.

${ }^{453}$ Ibid, p 81. See also City of London's Case (1610) 8 Coke's Reports 121 (77 ER 665) at 126. See also Bateson, n 5, vol 1, p 211.

${ }^{454}$ Bateson, $\mathrm{n} 5$, vol 2, $\mathrm{p}$ lvii 'The London creditor's right to 'attach' debts which were due to his debtor, and to use these as part of the debtor's assets, resembles the ancient royal right, which was not the right of ordinary men, to distrain the debtor of the king's debtor.' See also Anon, $n$ 3, pp 113- 140; Halsbury, n 1, vol 12(1), para 628, n 13 (since the decision of London Corp v London Joint Stock Bank (1881) 6 App Cas 393, rejecting the modern extension of the custom, it had fallen into disuse). This was also stated in 1894, see RC, n 14, vol 18, pp 47 and 374 . See also Norton, n 3, p 300 and Bacon, n 11, vol 2, pp 258-62. See also Brandon (1861) and Locke (1853).

455 (a) and (b) these writs no longer exist; (c), (d), (f), (i), (k), (l) \& (m) general law now applies; (g) \& (j) relate to the court of Hustings which no longer operates; (e), (h) \& (j) wager of law, outlawry and attaint have been abolished. For criticism of the rule of foreign attachment see RC, n 14, vol 18, p 374 (commissioners in 1837 considered that it was 'inexpedient' that it differed from the general law).

${ }^{456}$ The 1st charter of William I recognised this (see 1). See also Norton, n 3, p 266 and Riley, n 3, p 361. Bateson, n 5, vol 2, p xcvii 'Bracton ascribes to the Londoners a custom which gave them the power to dispose of the whole of the [ir] chattels by will, and he argues enthusiastically in favor of this freedom, which was eventually to become the freedom of those who were not Londoners.' Also, p xciv, 'The statutes of 32 \& 34 Henry VIII [ie. 32 Hen VIII c 1 (1540) \& 34 Hen VIII c 5 (1542-3)] deprived the borough custom of much of its value, the general law, so far 
to be admitted to probate in the Court of Hustings. ${ }^{457}$ This court no longer operates. A $1^{\text {st }}$ charter of Edward III of 6 March 1327 empowers citizens to hold their lands in mortmain, which mortmain no longer exists. ${ }^{458}$ It was also a custom of London that a third of a freeman's personal estate (whether by will or intestacy) passed to his wife, a third to his children (half to his wife if no children and half to children if no wife) and a third to the administrator. ${ }^{459}$ This custom was abolished by $1856 .{ }^{460}$

Other London customs elated to the manner of pleadings in the court of Hustings, mayor's court, sheriff's court as well as the other courts referred to in $\mathbf{4}$, all of which courts no longer operate. ${ }^{461}$ Further, it may be noted that many London customs were altered over the course of time by the court of Common Council. ${ }^{462}$

In conclusion, liberties of the City in respect of amercements, lands, promises, debts and wills are obsolete. They have all been superceded by the general law.

\section{Liberty - Evidence of Customs of the City}

A $1^{\text {st }}$ charter of Edward III of 9 November 1462 provides that the mayor and aldermen shall testify, via the recorder, whether a custom of London exists:

the ...mayor and aldermen... shall record, testify and declare, whether such be a custom or not, by the recorder of the same city... by word of mouth; and that there may be speedy process by that record, certificate, and declaration, such custom so alleged shall be allowed for a custom, or accounted not for a custom, without any jury therefore to be taken, or further process thereon to be made. ${ }^{463}$

This is confirmed in a 1 st charter of Charles I of 18 October $1638 .{ }^{464}$ As Pulling noted in 1854, recording a custom by word of mouth was made in times when many people were illiterate and when every legal form and act was done and pronounced in the presence of witnesses and lived only in their memory. ${ }^{465}$ This oral method of evidencing London customs applied even when the parties were in court. ${ }^{466}$ However, in practice, where such a custom was denied a writ of certiorari was issued and a certificate was issued via the recorder indicating whether such a custom existed or not. ${ }^{467}$ Such a method today is unnecessary and it creates problems since as Halsbury

as land held in socage was concerned, being brought into line with borough custom by his legislation.' See also ibid, $\mathrm{p} 99$. See also Halsbury, $\mathrm{n}$ 1, vol 12(1), para $628 \mathrm{n} 17$ who note that most cities had this custom of free choice to devise.

457 See also Thomas, n 21, p 156. See also Bateson, n 5, vol 2, p cxxxix and p 195. RC, n 14, vol 18, p 373 (in 1894) noted that no wills had been registered in the court of Hustings since 1688.

458 'we have granted... to the said citizens, that they, their heirs and successors, may bequeath their tenements within the liberties of the ... city, as well in mortmain as in other manner, as of ancient time they have been accustomed to do.' Birch, n 3, p 54. See also Bateson, n 5, vol 2, p xcii and Norton, n 3, p 349-51. For the abolition of the Mortmain Acts, see n 297.

${ }^{459}$ For an explanation see Blackstone, n 2, vol 2, pp 518-20. See also Norton, n 3, p 266; LL, n 3, pp 80-2; Bacon, n 11, vol 2, p 249 and Halsbury, n 1, vol 12(1), para 628, n 17.

${ }^{460} 11$ Geo 1 c 18 s 7 (1724) and Administration of Intestate's Estates 1856, s1 (rep). See also Bohun, n 1, pp 208-20; Jacob, n 3, pp 2, 70-1, 74-6, 163-5 and Halsbury, n 1, vol 12(1), para 628, n 16. For other liberties on restrictions on devises (all now obsolete) see Bohun, $\mathrm{n}$ 1, pp 73-5, 208-20; Jacob, n 3, pp 2-4 and Anon, n 3, pp 50, 69-110.

461 eg. Anon, n 3, p 49 et seq. (ability of mayor to take recognizances, pp 50, 52) and Pulling, n 3, p 21 (power of the mayor to take recognizances of any person of full age or unmarried women, for the payment of money belonging to orphans of freemen of the City even though the debt was contracted out of London). See also Bacon, n 11, vol 2, p 246.

462 Pulling, n 3, p 49 (in 1854) 'various customs of London relating to wills, executorships, orphans, apprentices, and trade in general, together with the practice of the city courts of justice, have been from time to time materially altered by the [Court of Common Council].'

${ }^{463}$ See Birch, n 3, p 77. This process of word of mouth was not held in high regard by the justices of the Iter of London in 1321 , see Sharpe, $\mathrm{n}$ 30 , vol 1, p 145 .

464 'the mayor and aldermen of the...city...may record, testify, and declare by word of mouth, by the recorder ...those customs; and that by such record, testimony, and declaration, without taking any jury thereupon, or making any further process, they may speedily proceed to the caption or determination of the plea, deed, cause or business.' See Birch, n 3, pp 186-7. Also, Blackstone, n 2, vol 1, p 76 \& vol 3, p 334.

${ }^{465}$ Pulling, $\mathrm{n} 3$, p 4. See also Norton, n 3, pp 375-6.

466 Ibid, "whenever any issue should be taken on any plea or upon the custom of London between any parties in pleading (even though the city were parties themselves), or of any thing in plea, act, and question touching the said customs, be moved or happen in any court, the mayor and aldermen for the time being should record, testify, and declare whether such be a custom or not by the recorder for the time being by word of mouth, and that there may be speedy process by that record, certificate and declaration, such custom so alleged shall be allowed for custom or not, without the verdict of a jury, or further protest.'

${ }^{467}$ For the rather laborious process see Pulling, $n 3$, pp 6-8. The form of the certifícate was 'We, the said mayor and aldermen of the said city, by [ ], recorder of the said city, by word of mouth of the said recorder, according to the custom of the said city, do, in obedience to the said annexed 
notes, it appears that the certificate cannot be challenged in court; nor can the parties ask the court to request that it be remitted for re-consideration. ${ }^{468}$ Further, in practice, the courts have taken notice of London customs by reference to the law reports. ${ }^{469}$ Also, today, it would be inappropriate for the recorder of London (the most senior judge at the Central Criminal Court) to evidence City customs - not least because his knowledge of them would likely be no better than that of anyone else. Thus, the general law of evidencing customs is more appropriate ${ }^{470}$ (and would be fairer) than this liberty, which should be dispensed with.

In conclusion, the method of evidencing customs of London should be dispensed with and the general law in respect of evidencing customs applied.

\section{Are There Any Other Liberties and Customs Of London?}

Besides, the liberties and customs referred to, it is pertinent to consider whether there are any others.

\subsection{Liberties and Customs pre-Magna Carta 1297}

As noted in 1, Magna Carta (1297), still extant, provides that:

'the city of London shall have all the old liberties and customs which it hath been used to have.'

Leaving aside those liberties contained in charters in the period 1133-1297 (see Appendix) and which it is asserted are now spent and should be repealed, it is contended that this wording in Magna Carta should now be repealed - on the basis that there are no 'liberties and customs' pre-1297 which are not otherwise obsolete. In respect of this it may be noted that, in the Anglo-Saxon era, very little legislation dealt with London in particular. Even less so, did the Crown grant special privileges to London - not least since it was not a town of major significance for most of that time. Anglo-Saxon laws (which are known of) and which made specific reference to London comprise:

- Certain laws which were probably issued c. 930-40 and which are called Athelstan VI (they are also called the Indicia Civitates Lundoniae). ${ }^{471}$ These mainly relate to guilds and they are palpably obsolete; ${ }^{472}$

- Certain laws which were probably issued c. 991-1002 and which are called the laws of Ethelred IV. They relate to tolls and to the trading rights of foreigners in respect of London. They, also, are palpably obsolete. $^{473}$

What about other liberties that might have been given to London by the Anglo-Saxons but which have been lost in the mists of time?

- Grants of liberties in Anglo-Saxon times were generally limited in nature. For example, the Cinque Ports were granted rights of $s a c$ and $\operatorname{soc}^{474}$ as well as of $t o l^{475}$ and theam. ${ }^{476}$ However, even if London had been granted the latter (since they had the former), tol and theam are now obsolete:

writ, humbly certify that in the said city of London, there is not now, nor has there immemoriably been, in the said city of London, such custom as in the said issue is stated.'

${ }^{468}$ Halsbury, n 1, vol 12(1), para 628. See also use of this custom in 1876, see RC, n 14, vol 17, pp 235-6.

${ }^{469}$ Noted by Halsbury, n 1, vol 12(1), para 628, n 4. The recorder was also important in declaring the customs of London to the court of Martin-le-Grand, see Pulling, n 3, p 116, which court no longer exists.

${ }^{470}$ See Halsbury, n 1, vol 12(1), para 628.

${ }^{471}$ Attenborough, n 21, pp 157-69. It commences 'These are the ordinances which have been agreed upon and confirmed with solemn declarations in our association by the bishops and reeves who belong to London...' See also Thomas, $\mathrm{n}$ 21, $\mathrm{p}$ ix and Bateson, $\mathrm{n} 5, \mathrm{p}$ xxxvii.

${ }^{472}$ They deal with the execution of thieves, indemnities for livestock, stolen cattle etc. See Inwood, n 3, p 43. See also 3 charters issued between 733-45 of Ethelbald, king of Mercia granting customs free access to London for the ships of two bishops and an abbess. Ibid, n 3, p 37.

${ }^{473}$ Robertson, n 21, pp 71-9. See also Bateson, n 5, p xxxvii and Liebermann, n 21, vol 3, pp 161-6.

${ }^{474}$ Also spelt sake and soke (or sac and socn), it was a grant of manorial jurisdiction, including the right to hold a court and collect fines for various offences. Fleta, n 144, p 101 'Soke means the franchise of a court of tenants, which we call soka. Sake, quittance of suit to a county and hundred courts.' AT Carter, A History of the English Courts (7th ed, 1944), p 2 'Courts of private jurisdiction, held in virtue of right, of 'sac' and 'soc', ie. the right to hold a court and the right to the profits therefrom.' For the London sokes, see $\mathbf{1 4 .}$

${ }^{475}$ Also spelt 'toll', it was probably a right to receive a tax on the sale of goods (or possibly, just the sale of cattle) at a market. See McBain, $n$ 4. Riley, n 3 (Munimenta, Liber Custumarum, pt 2), p 769 'A privilege granted by the sovereign to the vill or manor, of holding market, or, in other words, buying and selling on its own ground.'

${ }^{476}$ Also spelt theam, this was, probably, the right to take profits where a person charged with wrongfully possessing goods was able to vouch to warranty. See McBain, $n 4$ and Coke, n 12, vol 2, pp 323-7. Riley, n 3 (Munimenta, Liber Custumarum, pt 2), p 769 'The right of holding court for the taking and examination of warranties, vouched in favour of persons found in the possession of stolen goods.' 
- So too, are other liberties given to the Cinque Ports such as the right to levy fines for: blodwite, fledwit and mundbryce. ${ }^{477}$ These may also have been granted to the citizens of London, as well as others of a similar ilk. ${ }^{478}$ Even if so, they are obsolete;

- As for liberties existing from 1066-1215, Britton (writing c. 1290) lists common franchises granted by the Crown, post-1066. ${ }^{479}$ To the extent that London was granted any of these, and they have not otherwise been recorded in a charter, they are also obsolete.

In conclusion, the wording in Magna Carta 1297 relating to the liberties and customs of London should be repealed. Such liberties and customs are obsolete.

\subsection{Liberties and Customs post-1297}

As for other customs of the City post-1297 not previously mentioned, consideration may be given to specific legal texts on London throughout the centuries as well as to caselaw ${ }^{480}$ and the major, and minor, abridgments. ${ }^{481}$ The totality of these makes it unlikely that others may slip the net. In respect of those customs cited in such sources and which are not palpably obsolete today - reference may be made to the following: ${ }^{482}$

(a) Brothels and Adultery. A police constable of the City - having information that a man in his ward might be frequenting a brothel with lewd women (prostitutes) - might enter it and arrest the offender for a breach of the peace without a warrant, providing the man (it was not envisaged that women might be the offender) was in such company. ${ }^{483}$ This also applied in the case of persons suspected of committing adultery ${ }^{484}$ as well as in the case of chaplains (priests) suspected of fornication. ${ }^{485}$

${ }^{477}$ Blodwit (also spelt bloodwite and blodwyte) was a fine paid to the sovereign for the shedding of blood and fledwit for beating and striking. Mundbryce was the authority to try breaches of the king's peace and impose fines for the same. These liberties had been granted to the Cinque Ports. See McBain, $\mathrm{n} 4$.

${ }^{478}$ Fleta, n 144, p 102 refers to flemenesfreme (right to chattels of fugitives), wergeldthief (right to a thief who may be ransomed), fyrdwite (quittance of service in the army), wardwite (quittance of an amercement for not finding a person to stand guard in a castle or elsewhere), hangwite (quittance of amercement for a thief hanged without judgment), hamsocn (quittance of an amercement for entering another's house by force and unlawfully), hidegeld (quittance of a trespass against an erring bondsman), fyrdfare (quittance of going with the host). See also list in Riley, n 3 (Munimenta, Liber Albus III), pp 453-6 and in Sutherland (1982), pp 786-9 (explanation of words relating to franchises given on behalf of the Abbot of Peterborough).

${ }^{479}$ Britton (1901), p 62, 'Let inquiry also be made, what persons in the county claim to have return of our writs, or custody of our goal, or that the justices in eyre shall come into their franchises, or to have their own coroners, or chattels of felons, or view of frankpledge, or the franchise of infangthef or outfangthef and gallows, or fairs, or markets, or the execution of the pillory or tumbrel,or to have wreck of the sea, or to have pleas de vetito namio in their courts, or to have lestage, or amercements of their tenants, or traverse, or toll, or estray, or murage, or pontage, or cheiminage, or warren in his demesne lands or in other lands, or to be quit of doing suit at our county court, or at sheriffs' tourns, or at our views of frankpledge, or to be quit of mestage, murage, or pontage, or who may claim any kind of liberty more than other people.' See also eg. liberties granted to a London soke in 1136-38, Page n 3, p 141.

${ }^{480}$ See texts cited in $\mathrm{n} 3$ and other texts cited by Sweet and Maxwell. Of particular use are: Arnold (who recorded the liberties of the City in 1502), Calthrop (in 1670), Bohun (in 1723), Jacob (in 1732), Anon (in 1674) and Pulling (in 1854). See also Selden Society, vol 113, pp 3-4.

${ }^{481}$ See $n$ 11. Of particular use are: Viner, vol 7 (writing in 1752), Bacon, vol 2 (in 1798) and Comyns, vol 5 (in 1825).

${ }^{482}$ Halsbury, n 1, vol 12(1), para 268 cites some ecclesiastical customs in the City but notes that most of them were customs of individual parishes rather than of the City as such. In respect of the former he cites customs, that: (a) rectors of churches may make leases at a vestry, see Hastynges $v$ Rogers (1551); (b) churchwardens of every parish owned the pews and seats and could assign them at their pleasure, see Ballard $v$ Kydde (1493).

${ }^{483} \mathrm{Jacob}, \mathrm{n} 3, \mathrm{p} 44$. He also noted that constables had power to execute warrants throughout the City. Further, that those chosen to the office of constable were to place the king's arms and the arms of the City over their doors, so that they might more easily be located. See also Jacob, n 3 , pp 160-1 (watch and ward).

${ }^{484}$ Bohun, $\mathrm{n} 1, \mathrm{p} 79$ 'if an information be made to a constable there, that one within the jurisdiction is with a woman in adultery, that he shall take the beadle, and others of the same parish, and go to the house, and if they find the man in adultery, they shall take him to the compter, and leave him there' See Coke, n 12, vol 3, p 205 ('but now these offences belong to the ecclesiastical court'). The punishment of those caught in fornication and adultery by parading them around London was encouraged by the Lollards in 1352, see Preest, n 258, p 183. Between 1400-40, no less than 60 clerks in holy orders were taken in adultery and put in prison by ward beadles, see Sharpe, n 30, p 255. See also Calthrop, n 3, p 117 (use of the Tun (a prison at Cornhill) for such people) and Riley, n 3, (Munimenta, Liber Albus), pp cvi-ii.

${ }^{485}$ If a chaplain (priest) kept any woman in his chamber (room) suspiciously a man might come to his chamber with the constable (beadle) of the ward and search. See YB 2 Hen 4, pl 51, fo 12b (1400)(action of trespass by a priest. Defendant fiancee entered his chamber to recover property belonging to him, including a ring). See also City of London's Case (1610) 8 Coke's Reports 121 (77 ER 665) at 126a; Viner, n 11, vol 7, p 241; Anon, n 3, p 51 and Bacon, n 11, vol 2, p 247. 
Today, there are more modern laws governing prostitution. And adultery and fornication are not crimes. Firther, the sheriff's court, or court of wardmote, before whom the constable might bring such people, no longer operate;

(b) Carting Whores. It is said that a woman found to be a whore at a wardmote inquest could be carted and whipped through the streets of the City ${ }^{486}$ - although this was doubted by Lord Mansfield in 1783 on the basis that such a custom had not been proved. ${ }^{487}$ Today, wardmote inquests no longer exist and the cart (tumbrel) has long been obsolete; ${ }^{488}$

(c) Insulting Words. It was a custom to maintain an action on the case in the London courts for insulting words not otherwise actionable in the courts of Westminster. For example, an action for calling a woman a 'whore' - since women could be punished by carting (see above). ${ }^{489}$ This right was said to be available to all the inhabitants of London. ${ }^{490}$ It was also a custom to fine, and imprison a person, for insulting words spoken of an aldermen of the City. ${ }^{491}$ These punishments seem only to have occurred in the specialised courts of London (eg. the sheriff's court, court of Hustings and the mayor's court), which courts no longer operate. Today, the general law of defamation applies. It may also be noted that defamation is no longer a crime (criminal libel having been abolished in 2010). Thus, a civil action only lies;

(d) Funeral Expenses. A freeman who died, leaving children, had his funeral expenses paid by the City out of the estates of orphans of whom the mayor and aldermen were guardians. ${ }^{492}$ This no longer applies, the orphan's fund from which such expenses were paid, having been wound up long ago; ${ }^{493}$

(e) Refusing to Serve in Office. It was a custom to commit a person to prison for refusing to serve as mayor, sheriff or alderman. ${ }^{494}$ This is now governed by Acts of Common Council ${ }^{495}$ and the general law - although the general law on this is almost certainly obsolete; ${ }^{496}$

\footnotetext{
${ }^{486}$ Riley, n 3, (Munimenta, Liber Albus), pp cvi 'A woman convicted of being a common courtesan was taken from the prison (the Tun probably) to Aldgate with a hood of rayed cloth on her head, and a white wand in her hand. Thence she was led, accompanied by musicians, to the thewe (in Cheap, no doubt), where the nature of her offence was proclaimed. This done, she was escorted, through Cheap and to Newgate, to 'Cokkeslane' [now Cock Lane], without the walls, and there she had to take up her abode (demourere). On being found guilty of this offence a third time, she was similarly punished; in addition to which, her hair was cropped short while she was upon the thewe, and she was taken to one of the gates, and compelled to forswear the City for the rest of her life.' See also pp 180-2.

${ }^{487}$ Bohun, $\mathrm{n}$ 1, pp 189-90 (a whore in London is to suffer corporal punishment, viz carting and whipping: And it is an offence presentable at the wardmote inquest and there punishable). Cf. Bacon, n 11, vol 2, p 246-7 and Stainton and his wife v Jones (1783) before Lord Mansfield. See 1 Douglas Reports 380 at note 96 (1783) (99 ER 245). See also Jacob, n 3, p 167; Sharpe, n 30, p 222 and D’Anvers, n 11, vol 2, p 311.

${ }^{488}$ The tumbrel was a dungcart used for the punishment of brewers, bakers etc. See Coke, vol 3, p 219. See also Riley, n 3 (Munimenta, Liber Custumarum, pt 2), p 771.

489 Bohun, n 1, pp 189-90. Bower and his wife v Cooper (1637) Cro Car 487 (79 ER 1020)(procedendo granted in a case removed by habeus corpus from London for calling a woman a whore). Cf. Hart's Case (1633) Cro Car 315 (79 ER 907) (procedendo refused to a suit removed from the sheriff's court in London for calling a woman a whore. Action lay in the spiritual courts only). See also Viner, n 11, vol 7, p 195; Jacob, n 3, p 167; Anon, n 3, pp 50-1; Rolle, n 11, vol 1, p 550 and vol 2, p 69. See also March's New Reports 107, pl 184 (82 ER 432)(1641). 490 Jacon, n 3, p 167.

${ }^{491}$ Bohun, n 1, p 62; Jacob, n 3, p 94; Anon, n 3, pp 49-50. See also Riley, n 3, (Munimenta, Liber Albus), p civ. Pulling, n 3, p 31 'anciently it was considered, that if any one spoke opprobiously of an alderman, he might be punished for contempt by imprisonment, and if a freeman, might be disfranchised; but this was declared not to be legal, although such conduct may still be punished by a fine, provided, it is presumed, that the offence related to the alderman in his official capacity.' See Clark's Case (1678-9) 1 Ventr 327 (86 ER 212) (on a habeus corpus to the mayor of London disenfranchisement and committing of a freeman for speaking opprobrious words of an alderman). Cf. $R v$ Rogers (1702) 7 Mod 28 (87 ER 1074) (speaking contemptuously to an alderman while holding a wardmote is not indictable). See also Viner, n 11, vol 7, p 245 and Riley, $\mathrm{n} 3$ (Munimenta, Liber Albus), p civ.

${ }^{492}$ Letterbook D, n 3, p iv.

493 Pulling, n 3, p 114 who notes that the tax on inhabitants for the orphan's fund was repealed in 1795 (35 Geo III c 127).

494 Ibid, p 28 (in 1854) 'There is a fine of $£ 500$ on refusal to serve in public office; and it has been decided in an old case to be a good custom to imprison until the person elected takes the oath of office; but the office is now usually an object of ambition, and it is very rarely necessary to enforce any penalty for refusal to serve.' See also Anon, n 3, pp $49 \& 50$. For a refusal to serve as an alderman and imprisonment in 1528 , see Sharpe, $\mathrm{n} 30$, p 378. Also, Bateson, vol 2, p xxxvi (in 1415, in London, a man's house was sequestered on his refusing to serve as an alderman). See also Riley, n 3, (Memorials), p 601. For refusal to serve as a sheriff see Calthrop, n 3, p 33 and Sharpe, n 30, vol 2, pp 63, 121, 338. See also, COL, n 3, p 13.
} 
(f) Orphans, Apprentices, Feme Sole and Couverts. There were various London customs in respect of orphans ${ }^{497}$ and apprenticeship. ${ }^{498}$ They are long obsolete. It was also a custom of the City that a married woman carrying on a trade apart from her husband within the City was liable as a feme sole. $^{499}$ This is also obsolete. Every married woman is liable for her debts and obligations as if she were a feme sole pursuant to the Law Reform (Married Women and Tortfeasors) Act 1935, s 1(b);

(g) Hostlers. It was said to be a custom of the City (and of Exeter) that an unpaid common innkeeper might keep (ie. exercise a lien over), and sell, an indebted guest's horse left at his inn once it had eaten its value. ${ }^{500}$ Even assuming there was such a custom, the Hotel Proprietor's Act 1956 prevents the exercise of a lien over a guest's horse. As to sale, statute now applies. The Innkeeper's Act 1878 provides that a common innkeeper may sell a guest's horse for debts arising from the upkeep of the same; ${ }^{501}$

(h) Taverns. A former custom of the mayor to designate places for taverns etc - and to imprison a person for erecting one in other places - was held good in 1639. ${ }^{502}$ The licensing of taverns (that is, pubs) is now governed by the general law;

(i) Hanging out Signs. A $1^{\text {st }}$ charter of Charles I of 18 October 1638 provides that it is lawful for citizens to hang out signs to their houses and shops. ${ }^{503}$ This liberty became a nuisance and Norton records that it was ended in the middle of the $18^{\text {th }}$ century. ${ }^{504}$ The hanging out of signs is now governed by the general law - including the law on nuisance;

(j) Ceremonial Customs. There are various ceremonial customs relating to the City. ${ }^{505}$ However, it is asserted these customs are not legally enforceable as such, not existing prior to 1189 .

It is asserted that the above customs (excluding (j)) are obsolete being, in many instances, superceded by the general law. ${ }^{506}$

\section{Charters Not Previously Discussed}

Finally, reference may be made to various charters concerning the City not previously discussed which are obsolete.

- A charter of king John (1199-1216) of 20 March 1202 excluded the weavers from the City; ${ }^{507}$

\footnotetext{
495 See Act of 17 April 1812, RC n 14, vol 2, p 24 (fine of $£ 500$ for aldermen). Also, Act of Common Council of 25 September 1800 (within 14 days of election, subject to a penalty of $£ 1 \mathrm{~K}$, the mayor must signify in writing his consent to accept office). See generally, CMC, n 14, pp 29 , 31 (mayor), p 32 (aldermen), pp 36-7 (sheriff).

${ }^{496}$ See McBain (2009), p 113.

${ }^{497}$ See Bohun, n 1, 313-36; Anon, n 3, pp 60-9; Jacob, n 3, pp 121-5 and Bacon, n 11, vol 2, pp 248-9. See also Halsbury, n 1, vol 12(1), para $268 \mathrm{n} 19$ (wardship of orphan children of freeman belonged to the City) and Bateson, n 5, vol 1, pp 229-30 and vol 2, p 149.

${ }^{498}$ See generally, Bohun, n 1, pp 338-47; LL, n 3, pp 43-5: Jacob, n 3, pp 6-9; Bacon, n 11, vol 2, p 257 and Halsbury, n 1, vol 12(1), para 268 (infants could bind themselves as apprentices at 14).

499 Ibid, pp 187-8; Anon, n 3, p 59; Halsbury, n 1, vol 12(1), para 628 n 15; Bateson, n 5, vol 1, pp 227 and Bacon, n 11, vol 2, p 257.

${ }^{500}$ Moss v Townsend (1612) 1 Bulst 207 (80 ER 893). See also Halsbury, n 1, vol 12(1), para 628 (it fails to note this right only applied to common innkeepers (hotelkeepers)). See also Bacon, n 11, vol 2, p 247.

${ }^{501}$ See also McBain (2006), pp 747-8.

${ }^{502}$ Anon, n 3, p 54 citing Crisp v Prat (1639) March's New Reports pl 34 (82 ER 390). See also Pulling, n 3, p 20 and Viner, n 11, vol 7, p 243.

503 'may and shall be lawful to the citizens... to expose and hang in and over the streets and ways and alleys of the said city, and suburbs of the same, signs and posts of signs affixed to their houses and shops, for the better finding out such citizens' dwellings, shops, arts and occupations.' See Birch, n 3, p 192. See also Bohun, n 1, p 31 and Jacob, n 3, p 144.

${ }^{504}$ Norton, n 3, p 403 'This nuisance existed until the middle of the last century.'

${ }^{505}$ Glasspol (in 1924), n 220, referred to various ceremonial customs including: (a) the mayor being custodian of the city seal (no longer applicable); (b) the ceremonial dress of city officers; (c) ceremonials concerning the election of the mayor, sheriff etc; (d) 'chopping the faggots' (obs); (d) proclamations at the opening, and closing, of the court of Hustings (obs); (e) proclaiming the sovereign - which is not a City custom as such. See Halsbury, n 1, vol 8(2), para 916, n 2.

${ }^{506}$ It may be noted that, by 1798, when Bacon wrote, see n 11, vol 2, pp 244-62 the customs of London were few and most related to orphans, wills, feme coverts, landlord and tenant, debts and foreign attachment.

507 'we, at the request of our mayor and citizens of London, have granted, and by this our present writing confirmed, that the guild of weavers shall not from henceforth be in the city of London, neither shall be at all maintained.' See Birch, n 3, p 18. Also, Letterbook C, n 3 , p 55 and Norton, $\mathrm{n} 3$, pp 313-5. This charter was inoperative, see CMC, n 14, p 13. For the grant to the weavers of their guild in 1155-8, see Ballard, $n 5$, p 208).
} 
- A charter of remission of Henry III (1216-72) of 10 January 1266 stated that, on payment of 20,000 marks $[£ 13,333]$ by way of atonement for the crimes committed against the sovereign by the citizens of London, they would enjoy their former rights. ${ }^{508}$ The 'crimes' referred to comprised the support given by the citizens to the barons in their war against Henry III; ${ }^{509}$

- An $8^{\text {th }}$ Charter of Henry III of 26 March 1268 saved 'in all things the liberty of the church of Westminster to the abbots and monks of the same place, to be granted by the charters of us and our predecessors'. ${ }^{510}$ This liberty (soke) no longer exists;

- A $1^{\text {st }}$ charter of Edward III of 6 March 1327 provides that the Constable of the Tower of London has no power to arrest ships. ${ }^{511}$

These charters are now spent. Reference should also be made to a charter of 3 June 1341 of Edward III (1327-77). It provides, inter alia, in respect of the Common Council that:

where any customs theretofore used and obtained proved hard or defective, or any matters newly arising within the city needed amendment and no remedy had been previously provided; to apply and ordain a convenient remedy as often as it should seem expedient; so that the same were agreeable to good faith, and reason, for the common advantage of the citizens, and other liege subjects sojourning with them, and useful to king and people. ${ }^{512}$

It has been said that this confirms, in effect, the right of the City to 're-model its own constitution.' 513 This liberty was confirmed by an Act of Richard II (1377). ${ }^{514}$

In conclusion, these charters are spent, save for that of Edward III of 1341 as referred to above.

\section{Repealing the Liberties and Customs of the City}

It would seem manifest that the liberties and customs of the City have now either been superceded by provisions of general law or they are obsolete. It should also be re-called that such customs are contrary to the general law as well as being partial. ${ }^{515}$ Therefore, there should be good reason for their continued retention in modern times. It is asserted that all obsolete liberties and customs of the City should be repealed; and that any which remain should be provided for in subordinate legislation. Thus, it is asserted that:

- Magna Carta. The wording in Magna Carta ('the city of London shall have all the old liberties and customs which it hath been used to have.') should be repealed. There appear to be no such liberties or customs created prior to 1297 which still exist and which are not otherwise contained in charters or, in any case, not obsolete;

- City Charters. The charters of the City referred to in the Appendix should be repealed; their content being obsolete ${ }^{516}$

\footnotetext{
${ }^{508}$ On payment, Henry III did 'remit, forgive, and acquit, for us and us and our heirs, the citizens of London, and their heirs, of all crimes and trespasses whatsoever; and that the said citizens, as formerly, shall enjoy all their rights and liberties; and that from Christmas last they shall and may receive the rents and profits of all their lands and tenements whatsoever: and also, that the said citizens shall have all the goods and chattels of such criminals as have or shall be indicted on account of their late rebellion; except the goods and chattels of the persons already mentioned, which we have given to our son Edward; and also, all the lands and tenements that shall escheat to us, by reason of the aforesaid rebellion. And we likewise grant, that all the citizens confined in our several prisons shall be discharged; except those given as pledges to our son Edward [later Edward I, 1272-1307] for his prisoners, and those for citizens that are fled.' See Birch, n 3, pp 36-7. See also Riley, n 3 (Chronicles), pp $85-7$.

${ }^{509}$ Sharpe, n 30, p 101. A large amount of this fine remained unsatisfied by 1302. See Letterbook C, n 3, p II.

${ }^{510}$ Birch, $\mathrm{n} 3, \mathrm{p} 41$. This soke no longer exists.

511 'the constable of the Tower of London for the time being shall not make any prizes [prises], by land or by water, of victual or any thing whatsoever, of the men of the said city, nor of any other coming towards the said city, or going thence; neither shall or may arrest, or cause to be arrested, the ships or boats bringing victuals, or other such-like goods, to or from the said city.' See Birch, n 3, p 55. See also Riley, n 3 , pp 55-6 (constable seeks to arrest ships in 1262). Prisage was abolished in 1809, see n 359. See also Norton, n 3, p 358.

${ }^{512}$ See RC, n 14, vol 18, p 364. This charter is not cited in Birch, n 3.

${ }^{513}$ Ibid. The validity of Acts of Common Council under this power may 'be tried by the superior courts.' See also ibid, p 191.

${ }^{514}$ See also Halsbury, n 1, vol 29(2), para 40. Cf. CMC, n 14, p 12 (dates it 26 May 1341).

${ }^{515}$ City of London's Case (1610) 8 Coke's Reports 127 (77 ER 658) per Coke CJ, 'There are divers customs in London which are against common right, and the rule of the common law...' Day v Savadge (1614) Hobart 86 (80 ER 235) 'such customs as are of the nature of local laws, peculiar laws for that city, general to all the citizens, differing from the general law of the kingdom.'

516 The Commissioners in 1854, see RC-54, n 14, p xv, stated 'the present condition of the Corporation charters is far from satisfactory, and leads in practice to considerable inconvenience, and occasionally even to great hardship on individuals.' Also, 'They refer often to a state of
} 
- Remaining Liberties and Customs. Such liberties and customs of the City as still exist should be set out in legislation - in a statutory instrument. It asserted that the number of these will be very small - even on a generous estimate. ${ }^{517} \mathrm{I}$ believe the only City customs which still exist are ceremonial ones that relate to the coronation (and thus, are coronation customs and not City ones) or which are military ones (carrying of the mayor's sword, greeting the sovereign at the boundaries of the City etc). However, these (one would argue) are ceremonial customs - and not legally enforceable ones.

As to the obsolete nature of the liberties and customs of the City discussed in this article, the position may be summarised as follows:

- Anglo-Saxon Liberties. The City were granted a large number of Anglo-Saxon liberties viz. freedom from scot and lot, danegeld, murdrum, childwite, jeresgive, scotale, miskenning and wager of battle. Also, the right to pay the same tallage and aids as other citizens, to pay a maximum sum for amercements and rights of escheat, infrangthef and outfangthef. All these are palpably obsolete and some have been expressly repealed by legislation. ${ }^{518}$ The remainder should be (many of them are also contained in borough and town charters - as well as those of the Cinque Ports); ${ }^{519}$

- Waif, Estray, Tolls. It is asserted that, generally, rights of waif and estray should be abolished. ${ }^{520}$ Also, any rights in relation to any coronation banquet since it has been in abeyance for nearly 200 years. ${ }^{521}$ All tolls by way of Crown grant (ie. charter or patent) should also be abolished, being obsolete. ${ }^{52}$ Thus, exemption of London citizens from the same would also go;

- War, Billeting, Lands etc. Liberties granted to the City in respect of war and billeting have been superceded by general legislation. So too, special rights in respect of: lands, promises, debts, wills, orphans, apprentices, feme sole, hostlers and defamatory words. Also, all restrictions on merchants and brokers - as well as: (a) the office of clerk of the market; (b) courts of piepowder; (c) market overt; (d) purveyance; and (e) the ability to impose charges on the weighing, carriage, survey and measurement of imported goods. Even if any of these have not been repealed they should be ${ }^{523}$ since there is no good reason why the general law should not prevail. Other customs of the City (see 19) are also obsolete - as well as hunting rights (see 11);

- Mayor's Offices. The mayor continues to hold obsolete offices which should be abolished. ${ }^{524}$ It is also asserted that the right of the mayor (as well as that of sheriffs or aldermen) to sit in the Central Criminal Court (the Old Bailey) as judges should also end, since they, in fact, have no judicial function; ${ }^{525}$

\footnotetext{
things which has wholly passed away, and their language has therefore to be explained often through the doubtful medium of antiquarian research.' They recommended that a new charter be issued to contain all useful material from the older ones and all such customs of the City as it might be deemed expedient to preserve (ibid, $\mathrm{p}$ xxxvii, this was not effected). They thought there were some 120 charters in all. However, having regard to the charters referred to in Birch, $\mathrm{n} 3$ and CMC, $\mathrm{n}$ 14, pp 5-27, this figure is too high and the likely figure is half that. See also Appendix.

517 The Commissioners in 1894, see RC, n 14, vol 17, p 23 stated, 'The customs of the [City of London], so far as they are inconsistent with the common law, remain to be considered. The only important customs at present appear to be those of market overt and foreign attachment. Of these the latter is practially obsolete.' Foreign attachment remains obsolete and market overt was abolished in 1994.

${ }^{518}$ Murdrum was repealed by legislation (see $\mathrm{n} 138$ ) as was wager of battle (see $\mathrm{n} 142$ ).

519 ie. 'For the avoidance of doubt the following are abolished, all Anglo-Saxon: (a) taxes and tolls (including bridtol); (b) forms of amercement, including childwite, letherwite (leirwite), jeresgive, scotale, miskenning, blodwit, fledwit, mundbryce and fyrdwite; (c) independent or exclusive jurisdiction, including sac and soc (sake and soke); (d) privileges in respect of the seizure of criminals, including infangthef and outfangthef; (e) toll and theam.' A reference to 'toll and theam' is made separate to a reference to 'tolls' since the precise nature of 'toll and theam' is unclear, see ns $475 \& 476$. A separate reference to letherwite is also made since it may not be identical with childwite.

${ }^{520}$ ie.'The following Crown prerogatives, being obsolete, are abolished; the right of the Crown to: (a) waifs; (b) estrays'. Also, abolished are 'any rights in respect of any corporation banquet (including the office of butler or assistant thereto).'

521 See $\mathrm{n} 259$.

522 This is important since, after the Anglo-Saxons, the Crown imposed tolls and franchised the same. Thus, 'The following Crown prerogatives, being obsolete, are abolished, the right of the Crown to: (a) impose non-statutory tolls together with any franchise of the same. These include tolls in respect of: pontage, murage, cheminage (chimmage), pavage (paviage), passage, lastage (lestage), stallage, pickage (piccage), aquage (ewage); scavage, tronage, boscage, cranage, wharfage, anchorage, loadage, primage, groundage, passage, herbage and pannage.'

${ }^{523}$ Thus, the Weights and Measures Act 1824, s 25 and the saving in the Weights and Measures Act 1985, s 90 should be repealed.

524 'The following offices of the mayor of the City of London are abolished: (a) office of escheator; (b) office of admiral of the port of London; (c) office of chief magistrate; (d) office of guager; (e) office of clerk of the market; (f) office of coroner (g) office of outroper; (h) office of keeper of the great beam; (i) any office at a coronation banquet of the sovereign.'
} 
- Election of the Mayor. The right of the City to elect a mayor should be enacted in legislation, to also replace the City of London (Various Powers) Act 1959, s 5 (it deals with the mayor's presentation to the sovereign); ${ }^{526}$

- Sheriffs and Aldermen. If all the charters in the Appendix are repealed, it is asserted that legislation is not required in relation to the election of the two sheriffs for the City - since that office now belongs to the City. ${ }^{527}$ Nor for any matters concerning aldermen, the chamberlain or the common clerk - provision for all of which can be made in an Act of Common Council, if required; ${ }^{528}$

- Courts. The courts of Hustings, the sheriff's court and the court of the chamberlain should be abolished;

- $\quad$ Soil of the City. If the charters of the City in the Appendix are repealed, confirmation may be required as to the right of the City to the soil of the Square Mile. ${ }^{530}$ However, this may not be necessary, since the City no longer holds this land in farm.

If the 'liberties and customs' and the charters of the City are abolished in the above manner - with any remaining customs being recorded in a SI, this would hugely clarify this opaque area of law. It would also help in modernising borough and town charters. ${ }^{531}$ Finally, it may be noted that many of the above changes do not require legislation; this can be achieved by an Act of Common Council. Repeal of the charters relating to the City would require legislation, however. ${ }^{532}$ So too, any repeal of legislative provisions.

\section{Synopsis of City of London Charters ${ }^{533}$}

(1) 1st charter of William I of 1067 (a) The citizens (burgesses) in London are declared to be law-worthy as they were in the days of Edward the Confessor; (b) every child shall be his father's heir after his father's days; (c) 'I will not suffer any person to do you wrong.'

(2) $2^{\text {nd }}$ charter of William I William I grants a hide of land at Gyddesdune to one Deorman.

(3) 1 st charter of Henry I of c. 1133 (a) farms Middlesex to the citizens for $£ 300$; (b) citizens have power to choose a sheriff. Also, justices for keeping pleas of the Crown; (c) citizens shall not plead without the walls of the city for any plea; (d) free from scot and lot, danegeld, murdrum; (e) none obliged to wage battle; (f) a citizen impleaded concerning the pleas of the crown, shall discharge himself by his oath, which shall be adjudged within the City; (g) none of the king's household or any other shall be lodged in the City nor by force; (h) citizens (and their goods) to be free throughout England and the seaports of all toll, passage, lestage and all other customs; (i) the churches, barons, and citizens shall peacefully hold their sokes with all their customs so that the strangers that shall be lodged in the sokes shall pay custom only to him whom the soke appertains (or his officer); (j) no citizen should be amerced above 100s for any pecuniary punishment; $(\mathrm{k})$ no miskenning in the hustings, folkmote or in any other plea within the City; (l) hustings may sit once a week; (m) citizens to have their lands, promises, bonds, debts in the City and without; (n) if any take any toll or custom of any citizen, the latter shall have withernam; (o) all debtors who owe citizens any debts, shall pay them in London (or discharge them there). If they will not

\footnotetext{
525 'None of the mayor, aldermen or sheriffs of the City of London shall continue to sit as a judge in the Central Criminal Court. Nor shall they, while in office, be a justice of the peace.'

526 (a) The Corporation of London shall continue to have the right to elect a lord mayor annually. He shall be elected by the liverymen of the City of London assembled in Common Hall in the manner laid down in an Act of Common Council; (b) The presentation, and swearing, of the lord mayor shall take place in the Queen's bench division of the High Court or before the judges of that division on the second Saturday in November of that year.'

${ }^{527}$ The references in the charters to: the amercement of sheriffs, their not being compelled to take an oath, their to have forfeiture of victuals and their right to appoint deputies are all obsolete (see 3).

${ }^{528}$ The references in charters vis- $a$-vis aldermen to: their annual election, their retention of the common seal, their not to be put on any assizes and their not to be made tax collectors are obsolete (see 9.1). So too, references to the election of the chamberlain, common clerk and common sarjeant (see 9.2).

${ }^{529}$ At present, under the Administration of Justice Act 1977, they are in abeyance.

${ }^{530}$ See ns 299-302. The wording in the charters needs to be modernised in any case.

${ }^{531} \mathrm{COL}, \mathrm{n} 3, \mathrm{p} 6$ 'It has been estimated that the charters of nearly 150 boroughs in the British Isles have been modelled upon those of London.' Bateson, $\mathrm{n} 5$, vol 21, $\mathrm{p} \mathrm{xv}$ 'in what way [borough customs] were brought ultimately into such harmony that borough custom has ceased to be a matter of much practical interest.'

${ }_{532}$ See Pulling, n 3, p 3 citing, inter alia, 7 Ric II no 37 (1383). See also Comyns, n 11, vol 5, p 20.

${ }^{533}$ The best work on the charters is Birch, see $\mathrm{n}$ 3. See also Luffman, $\mathrm{n} 3$ and CMC, n 14, pp 5-27. This synopsis covers all the charters they refer to.
} 
pay (or discharge) them, citizens to have withernam; (p) citizens to have their chases to hunt in the Chilterns, Middlesex and Surrey as fully as their ancestors had.

(4) Charter of Henry II of c. 1155 (a) no citizen (save for the king's moneyers and officers) to be impleaded without the City walls except in respect of foreign tenures; (b) free of murdrum within the City and portsoken; (c) no citizen shall be forced to wage battle; (d) of pleas of the crown citizens may discharge themselves according to the old usage of the City; (e) no man to take lodging by force or by delivery of the marshall; (f) citizens shall be quit of toll and lestage throughout England and the seaports; (g) none shall be adjudged for amerciaments of money but according to the charter of Henry I (see (3)); (h) no miskenning in any plea within the City; (i) hustings to be kept once a week; (j) citizens to have their lands, tenures and promises and all their debts whosoever do owe them; (k) right be done to them according to the custom of the City of all their lands and tenures in the City and of all their debts lent at London; (1) huntings to be as in the time of Henry I (see (3)); (m) if any in England shall take any custom or toll of or from the men of London, after he shall fail of right, the sheriffs of London may take goods thereof at London; (n) free from bridtoll, childwite, jeresgive and scotale. The sheriff of London or any other bailiff may take no scotale; (o) confirmed liberties had in the time of Henry I (see (3)).

(5) 1 st Charter of Richard I of 23 April 1194 (a) citizens not to plead without the walls of the City (except for foreign tenures and the king's own moneyers and ministers); (b) no murdrum within the City and portsoken; (c) no citizen shall be forced to wage battle; (d) citizens may discharge themselves of pleas of the crown according to the ancient custom of the City (ie. by oath, see (3)) (e) none may take lodgings in the city by force or delivery of the marshall; (f) free from toll and lestage throughout the England and the sea ports; (g) none be adjudged of amerciaments save according to the time of Henry I (see (3)); (h) no miskenning in any plea within the City; (i) hustings only once a week; (j) citizens to have all their lands, tenures and promises and all other debts whosoever do owe them; $(\mathrm{k})$ right be done to them according to the custom of the City of all their lands and tenures in the City and of all debts which shall be lent in London and of promises there made pleas; (l) pleas shall be holden in London; (m) if any man take toll or custom from a citizen, after he shall fail of right, the sheriff to have withernam in London; (n) huntings to be as in the time of Henry I (see (3)); (n) acquit of all bridtoll, childwite, jeresgive and scotale so that no sheriff shall make scotale; (o) confirms liberties of Henry I (see (3)).

(6) 2nd Charter of Richard I of 14 July 1197 (a) all wears in the Thames to be removed; (b) keeper of the Tower of London is not in the future to demand (or exact) anything of any person by reason of the wears.

(7) 1st Charter of John of 17 June 1199 (a) citizens not to plead without the walls of the City (excepting foreign tenures and the king's moneyers and ministers); (b) no murdrum in the city and portsoken; (c) no citizen shall be forced to wage battle; (d) citizens may discharge themselves of pleas of the crown according to the ancient custom of the City; (e) none may take lodgings in the City or portsoken by force or delivery of the marshall; (f) free from toll and lastage and every other custom throughout England and beyond the seas; (g) none be adjudged of amerciaments save according to the time of Henry I (see (3)); (h) no miskenning in any plea within the City; (i) hustings only once a week; (j) citizens have all their lands, tenures and promises and all other debts whosoever owe them; (j) right be done to them according to the custom of the City of all their lands and tenures which they have within the City and of all debts which shall be lent in London and that pleas of all promises there made shall be held in London; (k) if any man shall take toll or custom of citizens, after he shall fail of right, the sheriff of London to have withernam in London; (1) huntings to be as in the time of Henry I (see (3)); (n) acquit of all bridtoll, childwite, jeresgive and scotale so that no sheriff shall make scotale; (o) confirms liberties of Henry I (see (3)).

(8) $2^{\text {nd }}$ Charter of John of 17 June 1199 (a) all wears in the Thames or in the Medway to be removed.No wears to be put in the future, on fine of $£ 10$; (b) keeper of the Tower of London is not for the future to demand or exact any thing of any person by reason of the wears.

(9) $3^{\text {rd }}$ Charter of John of 5 July 1199 (a) confirms to the citizens the sheriffwicks of London and Middlesex with all the customs belonging to them for $£ 300 \mathrm{pa}$; (b) citizens free to elect (and remove) their sheriffs; (c) sheriffs to answer to the justices of the exchequer for things for which they are responsible; (d) if sheriffs unable to satisfy the amerciaments and farm, citizens accountable; (e) sheriffs not to be amerced above $£ 20$; (f) if sheriffs commit any offence by which they incur loss of their lives or members, they shall adjudged according to the laws of the City; (g) confirmation of the sheriffwick of London and Middlesex at $£ 300 \mathrm{pa}$; (h) forbids all persons to do any damage to the citizens in things that belong to the sherriffwick; (i) if farm alienated, the same applies re acquittal of farm (ie. by payment to the exchequer). 
(10) $4^{\text {th }}$ Charter of John of 20 March 1202 (a) Guild of weavers not to be in the City; (b) citizens to pay the king 20 marks a year in lieu of former gift of the weavers of 18 marks. $^{534}$

(11) 5th Charter of John of 9 May 1215 (a) grants and confirms the citizens the right to elect a mayor every year who 'to us may be faithful, discreet, and fit for the government of the City'; (b) to be presented to the king (in his absence, to his justices); (c) mayor to give an oath to the sovereign to be faithful; (d) at the end of the year to elect another or retain the same mayor by presenting him again to the king (in his absence, to his justices); (e) confirms all previous liberties, saving the chamberlainship.

(12) $1^{\text {st }}$ Charter of Henry III of 18 February 1227 (a) confirms sheriffwick of London and Middlesex at $£ 300$ pa; (b) liberty of citizens to elect, and remove, their sheriffs; (c) sheriffs to answer to the justices of the exchequer for things for which they are responsible; (d) if sheriffs unable to satisfy the amerciaments and the farm, the citizens liable; (d) amercements of the sheriffs not to exceed $£ 20$; (e) if sheriffs commit any offence whereby they ought to incur the loss of their lives or members, they shall be judged according to the law of the city; (e) repeats grant of sheriffwick of London and Middlesex at $£ 300$ pa; (f) forbids any to do any damage to the citizens in things that belong to the sheriffwick; (i) if farm alienated, it shall be in accordance with the charter of John (see (9)).

(13) $2^{\text {nd }}$ Charter of Henry III of 18 February 1227 (a) grants and confirms to the citizens the right to elect a mayor every year; (b) mayor to be to presented to the king (in his absence, to his justices); (c) mayor to give an oath to be faithful to the king; (d) at the end of the year citizens may elect another or retain the same presenting the same mayor again to the king (in his absence, to his justices); (e) confirms all previous liberties, saving the chamberlainship.

(14) $3^{\text {rd }}$ Charter of Henry III of 18 February 1227 Repeats (8).

(15) $4^{\text {th }}$ Charter of Henry III of 16 March 1227 (a) citizens not to plead without the walls of the City (excepting foreign tenures and the king's own moneyers and ministers); (b) no murdrum in the City and portsoken; (c) no citizen shall be forced to wage battle; (d) citizens may discharge themselves of pleas of the crown according to the ancient custom of the City; (e) none may take lodgings in the City or portsoken by force or delivery of the marshall; (f) free from toll and lastage and all other customs throughout England and beyond the sea; (g) none be adjudged of amerciaments save according to the time of Henry I (see (3)); (h) no miskenning in any plea within the City; (i) hustings only once a week; (j) citizens to have their lands, promises and debts whosoever owe them; (k) right be done to them of their lands and tenures in the City according to the custom of the City; (l) pleas of all debts lent in London and of all promises there made to be in London; (m) if any shall take toll or custom of the men of London after he shall fail of right the sheriff of London may take goods thereof in London; (n) huntings to be as in the time of Henry I (see (3)); (n) acquit of all bridtoll, childwite, jeresgive and scotale so that no sheriff shall make scotale; (o) confirms liberties of Henry I (see (3)).

(16) $5^{\text {th }}$ Charter of Henry III of 18 August 1227 (a) grants and confirms the liberty of the warren of Staines to the inhabitants of the county of Middlesex; (b) the same to be diswarrened and disaforested for ever so that their heirs and successors may have the liberties of warren and forest, to till and plough their lands, cut wood etc without impediment from the king's warreners or foresters.

(17) Charter of Henry III of 26 February 1246 (a) the king confirms the farm of Queenhithe to the City in 1246 for $£ 50$ pa by the Earl of Cornwall (the king’s brother)

(18) $6^{\text {th }}$ Charter of Henry III of 12 June 1253 (a) grants and confirms to the mayor and citizens the liberties and free customs they had in previous reigns; (b) mayor to be presented to the barons of exchequer in the absence of the king; (c) allows sheriffs $£ 7$ pa on account of the liberty (soke) of St Paul's; (d) citizens throughout all his dominions to be quit of all toll and custom as in previous charters granted.

(19) $7^{\text {th }}$ Charter of Henry III of 10 January $1266{ }^{535}$ (a) in consideration of 20,000 marks by way of atonement for crimes and misdemeanours against the king, the citizens shall enjoy their rights as formerly.

(20) $8^{\text {th }}$ Charter of Henry III of 26 March 1268 (a) none be compelled to plead without the walls of the City except (i) foreign tenures; (ii) king's moneyers and officers; (iii) such other matters as are contrary to the peace of the realm which were wont (according to the common law of the realm) to be determined in the parts where those other trespasses were done; (iv) pleas concerning merchandise which were wont to be

\footnotetext{
${ }^{534}$ For the grant to the weavers of London their guild, see Ballard, n 5, p 208.

${ }^{535}$ See also a charter of 11 January 1226 referred in the 1 st charter of Charles I (see no 41). See also CMC, n 14, p 7. Cf. Norton, n 3 , p 324. It is published in Luffman, n 3, p 56 and empowers the citizens to traffic with their commodities and merchandise as they please, quit of toll as in times past.
} 
determined according to the law merchant in boroughs and fairs); (b) no murdrum in the City and portsoken; (c) no citizen compelled to wage battle; (d) citizens may discharge themselves of pleas of the Crown according to the ancient custom, except only they should not swear on the graves of the dead but others be chosen to do that which the deceased should have done in his life; ${ }^{536}(\mathrm{e})$ none shall lodge within the walls of the City and the portsoken by force or by delivery of the marshall; (f) free of all tolls, lestage and customs except only due and ancient custom and prise of wine; if any shall take toll of them contrary to his grant, the sheriff of London shall have withernam in London; (g) hustings to be held once a week and for 1 day; (h) citizens to have right done to them in the City for their lands and tenures according to the ancient custom of the City; (i) liberty to appoint an attorney as elsewhere in the king's courts; ${ }^{537}$ (j) no miskenning in their pleas; (k) for all debts and promises made in London, the pleas be held according to the ancient custom; (l) quit of childwite, jeresgive and scotale so that no sheriff or bailiff shall make of scotale; (m) citizens to hold their lands, tenures, promises and debts as formerly; (n) no forestalling by merchants; (o) no goods to be put to sale before custom is levied; (p) no foreign merchant may buy (or sell) any wares which ought to be weighed or troned, unless by the king's beams or tron, on forfeiture of the same; (q) debts to be enrolled in the exchequer; (r) saving for the liberty (soke) of the church of Westminster to the abbots and monks of the same granted by us in charters to them.

(21) Charter of Edward I of 28 May $1298{ }^{538}$ (a) in the absence of the king and barons of the exchequer, mayor to be presented to the constable of the Tower, till the next coming of the king to Westminster or London; (b) citizens free from pannage, ${ }^{539}$ pontage and murage through the realm and the king's dominions; (c) sheriffs of London to be amerced as the sheriffs of the other counties; (d) citizens enjoy all their former liberties, freedoms, quittals and free customs.

(22) Constitutions of Edward II of 8 June $1319^{540}$ (a) mayor and sheriffs to be elected according to previous charters granted; (b) mayor to remain in office only 1 year; (c) sheriffs to have but two clerks and two sarjeants; (d) mayor have no other office belonging to the City but the office of mayor; nor draw to himself the sheriff's plea in the chamber of London nor hold other pleas than, according to ancient customs, he ought to hold; (e) aldermen to be removed annually and others chosen by the same wards; (f) tallages or aids to be assessed for the king's business or for the state and benefit of the City, after they shall be assessed not to be increased or heightened but by the common consent of the mayor and commonalty; (g) no strangers and no inhabitant to be admitted to the freedom of the City unless by surety of 6 honest and sufficient men of the mystery or trade in question; (h) each year enquiry be made if any freemen exercises merchandises in the City, of the goods of others not of the same freedom by calling them their own; if convicted, to lose their freedom; ${ }^{541}$ (i) scot and lot to be paid by all freemen; (j) non-resident freemen to pay scot and lot for their goods; (k) common seal to remain in the custody of 2 aldermen and 2 other commoners; (1) weights and scales of merchandises to be weighed between merchants and merchants to remain in the custody of honest and sufficient men of the City, expert in that office; (m) appointment of sheriff's deputies; (n) merchants not of the freedom of the City not to sell by retail wines (or other wares) in the City or suburbs ${ }^{.42}$ (o) no brokers in the City of any merchandises unless elected to this by merchants of the mysteries (trades) in which the brokers may have to exercise their offices; (p) non-freemen in the City to pay taxes for the maintenance of the City; (q) the keeping of London bridge (and the rents and profits thereof) to be kept by 2 honest and sufficient men of the City, other than the aldermen; (r) no sarjeant of the chamber of Guildhall to take a fee of the commonalty of the City or do execution unless chosen by the commonalty; (s) the chamberlain, common clerk and common sarjeant to be chosen by the commonalty and be removed according to the will of the City; ( $\mathrm{t}$ ) mayor, recorder, chamberlain and common clerk be content with their fees anciently appointed; (u) goods of the aldermen in aids, tallages and other contributions concerning the City to be taxed the same as the goods of

\footnotetext{
${ }^{536}$ A teutonic custom allowed in London to a person when accused. When a compurgator whom an accused had selected to exonerate him by oath as to his innocence, had died, the accused could deliver an oath over the dead man's grave as to what the deceased's verdict would have been - such to have the same effect as if the deceased had made it when alive. See Riley, n 3 (Chronicles), p 108; Bateson, n 3, vol 2, p xxxiii and Norton, $\mathrm{n} 3, \mathrm{p} 327$.

${ }^{537}$ See also Bateson, n 5, vol 2, pp cliv \& 10 and Norton, n 3, p 329 (noting that statute made this general in civil suits).

${ }^{538}$ The 1st charter of Charles I (see no 41) refers to a date of 18th April. See also CMC, n 14, p 7.

${ }^{539}$ Almost certainly this should be a reference to pavage. See $\mathrm{n} 348$.

${ }^{540}$ Not referred to in the $1^{\text {st }}$ charter of Charles (see no 41).

${ }^{541}$ This was called 'colouring of goods'. See n 397. See also Bateson, n 5, vol 2, p 181 and Norton, n 3, p 341.

${ }^{542}$ Cf. Riley, n 3, (Munimenta, Liber Albus), p xcv (regulation of Edward I).
} 
other citizens; (v) mayor aldermen and citizens may (by common consent) assess tallages on their own goods in the City (as well on rents as other things and on the mysteries) as they shall deem expedient without incurring the 'danger' of the king, his heirs or our ministers whomsoever.

(23) Charter of Edward II of 12 December 1321 (a) the aids given to him in the form of providing armed footmen at the castle of Leeds in Kent shall not be drawn into example. ${ }^{543}$

(24) $1^{\text {st }}$ Charter of Edward III of 6 March 1327 (a) liberties granted in former charters confirmed; (b) mayor to be one of the justices of goal delivery of Newgate; (c) citizens to have infangthef and outfangthef and chattels of felons of those in the City and the goal of Newgate; (d) citizens are only to pay $£ 300$ for the sheriffwicks of London and Middlesex; $;^{544}$ (e) liberty of citizens to devise their lands in mortmain; (f) sheriffs not to be amerced for the escape of thieves etc more than other sheriffs on this side of the Trent; (g) citizens not to be charged with the custody of those that seek sanctuary within their liberty, otherwise than of old accustomed; ${ }^{545}$ (h) citizens may remove all wears in the Thames and Medway; (i) foreign merchant that come to England obliged to sell their merchandise within 40 days and they should not keep houses but must sojourn with freemen; (j) neither the marshal, steward nor clerk of the market of the king's household shall sit, or exercise, any office within the City or draw any citizen to plead out of the City for events within; (k) no escheator may exercise any office within the City; the mayor shall exercise the office and take an oath for the due performance thereof and account with the king and his heirs; (1) citizens not obliged to go or send to war out of the City; $(\mathrm{m})$ constable of the Tower not to make any prizes of victual or anything of the men of the City, nor arrest any ships or boats bringing victual to the City to, or from, the City; (n) citizens may hold court of pie poudre in all fairs; (o) sheriffs not compelled to give any oaths at the exchequer save on giving up of their accounts; (p) restores former liberties and customs; (q) one writ of allowance of their charters should be sufficient and that no summons, attachments executions be made by any of the king's officers in the City but only by the officers of the City; (r) sheriffs may take the forfeiture of victuals and other things and merchandises according to the tenor of the charter; (s) if, in the last circuit of the justices sitting in the Tower of London, any thing was done or attempted contrary to their liberties of the City, the same should not be prejudicial to them; (t) citizens to be taxed in subsidies as other commons of the kingdom and not as citizens; (u) citizens to be quit of tallage; (v) liberties of the City not to be taken into the king's hands for any personal trespass or judgment of any minister of the City; (w) no king's purveyor to interrupt the sale of citizens' goods; (x) lands and tenements without the City belonging to citizens who are officers (ministers) of the City to be kept harmless as their tenements are within the said City; (y) no market shall be granted by the king within 7 miles in circuit of the City; (z) all inquisitions taken by the justices in London shall be taken in St Martin's Le Grand and not elsewhere, except inquisitions for the Tower of London and goal delivery of Newgate; (aa) no freemen to be impleaded or troubled at the exchequer or elsewhere by bill except it be by those things that concern the king and his heirs.

(25) $2^{\text {nd }}$ Charter of Edward III of 6 March 1237 (a) grants to the citizens the farm of the village of Southwark paying annually at the exchequer the due farm (of £10);

(26) $3^{\text {rd }}$ Charter of Edward III of 26 March 1337 (a) Statute of York (1335) (rep) not to affect the liberties of the citizens of London.

- Charter of Edward III of 3 June 1341 (a) enables the Common Council to amend customs. ${ }^{546}$

(27) $4^{\text {th }}$ Charter of Edward III of 10 June 1354 (a) sarjeants of London may bear maces of gold and silver in their attendance on the king or royal family.

(28) $5^{\text {th }}$ Charter of Edward III of 12 November $1376{ }^{547}$ (a) alderman each year on the feast of St Gregory the Pope shall cease to be such and shall not be chosen again. Instead, other aldermen shall be chosen out of the discreet citizens of good fame by the said wards from which the said aldermen were removed.

(29) $6^{\text {th }}$ Charter of Edward III of 4 November $1376{ }^{548}$ (a) no strangers (ie. no merchants not of the freedom of the City) should sell any wares by retail in the City (or suburbs), nor keep any house, nor be a broker in the same, saving the liberties previously granted to the merchants of High Almaine (Aquitaine).

\footnotetext{
${ }^{543}$ This charter is taken to exempt citizens from levies of men for carrying on war outside the City. See Birch, n 3, p 51. Also, CMC, n 14, p 10.

544 The sum had been increased to $£ 400$.

${ }^{545}$ On a felon taking sanctuary in a church it was the duty of the neighbours to watch him, until he had either surrendered or (in the presence of the proper officer) abjured the realm. If he escaped, the ward was amerced in the sum of 100s. See Riley, $n 3$ (Munimenta, Liber Albus), $\mathrm{p} 1$. Sanctuary was abolished by 21 Jac c 28 (1624). Cf Inwood, n 3, p 373 (Southwark mint).

${ }^{546}$ See 20. See also Luffman, n 3, pp 99-100 and Norton, n 3, pp 364-5.

${ }^{547}$ Not referred to in the $1^{\text {st }}$ charter of Charles (see no 41)
} 
○ Richard II (1377-99). Norton refers to a $1^{\text {st }}$ charter (inspeximus) of Richard II of 4 December $1377^{549}$ which (a) confirms previous charters; (b) recites a petition that citizens are not bound to obey precepts or process of any inferior authorities or jurisdictions (such as constables, marshalls, admirals or others) but only those of the king's own justices, and those at the king's suit under the great or privy seal, according to their charter. Also, declaration of the king that this privilege shall be enjoyed according to ancient usage; (c) inquisitions shall be taken by the citizens and not by others for all customs and impositions and also for all purprestures and other things of that nature arising in the City; (d) grants to the mayor and chamberlain the custody of all orphans, and the keeping of their lands and goods; (e) no protections granted by the king to persons making voyages on his service should be valid after the voyage or service was performed or against pleas of debt, account or trespass where a citizen was plaintiff and the cause of action is more than $£ 10$; (f) no writs shall issue to bring up a man confined in Newgate or other City prison for debts or damages adjudged to citizens, before the court of Exchequer to answer debts of the king or others sued in that court, unless the debts on examination prove genuine and have become due before imprisonment; (g) if any difficulty or ambiguity should arise on any article of the charters capable of various senses, the king, with the consent of his council, will put such interpretation on it as shall be consistent with good faith and reason. ${ }^{550}$

- Henry IV (1399-1413). Norton refers to a charter of Henry IV of 25 May $1400{ }^{551}$ which provides that the citizens (a) shall have the custody of the gates of Newgate and Ludgate as well as all other gates and posterns of the said City; (b) the office of the gathering of tolls and customs in Cheap and Billingsgate and Smithfield; (c) the grant of tronage. ${ }^{552}$

- Henry V (1413-22). Norton refers to two charters which confirm all previous charters. ${ }^{553}$

- Henry VI (1422-71). Norton refers to a charter of Henry VI dated 26 October $1445^{554}$ which grants to the citizens (a) all fines and forfeitures for crimes, chattels of fugitive felons, waifs, estrays, common soils, purprestures and improvements, wastes, streets, ways etc in the City and suburbs and in the waters of the Thames, and all the profits and rents to be derived therefrom.

(30) $1^{\text {st }}$ Charter of Edward IV of 9 November 1462 (a) confirmation of previous liberties; (b) mayor, recorder and certain aldermen to be JP's and justices of oyer and terminer; (c) customs of the City to be certified and recorded by word of mouth and that the mayor and aldermen declare via the recorder whether a thing be a custom or not; (d) no forfeiture for any crime or default in the mayor etc; (e) all inhabitants of the City liable to be assessed in all taxes, excepting only the merchants of Almaine; (f) aldermen not to be put on assizes, juries, attaints, recognizances or inquisitions out of the City; $(\mathrm{g})$ aldermen not to be tax collectors out of the City; (h) aldermen not to incur any penalty or imprisonment on account of refusing the office; (i) the town of Southwark having been granted to the City, the king also grants all waifs, strays etc and all treasure trove in the town and all goods and chattels of all traitors, felons, fugitives and outlaws. Also, all goods disclaimed or found in the town together with all escheats and forfeitures owing to the king as if the said town were in his own hands; (j) mayor and commonalty to have the assize of bread, wine etc in Southwick and all victuals and things saleable in the town and also the clerkship of the market belonging to it; (k) the execution and return of writs etc by the officers of the City shall prevail in the town of Southwick; neither the king's clerk of the market nor the sheriff or escheator of the county of Surrey shall intermeddle; (1) right of mayor etc to hold in Southwick a fair together with a court of piepoudre; (n) mayor and citizens (or their appointees) may take and arrest all felons, thieves etc apprehended in Southwark and commit them to Newgate; (o) mayor etc may have the town of Southwark and liberties in as large a manner as if the same were in the king's hands for the farm of $£ 10$ (rights of the Archbishop of Canterbury reserved).

\footnotetext{
${ }^{548}$ See also CMC, n 14, p 12. Cf. Luffman, n 3, p 109 (December not November).

${ }^{549}$ Norton, n 3, p 367. See also Birch, n 3 p 70 and Bohun, n 1, p 15. Not referred to in the $1^{\text {st }}$ charter of Charles (see no 41). See also CMC, n 14, p 16. For the text of this charter see Jeake, n 337, pp 9-10.

${ }_{550}$ Ibid, p 370 also cites a 2nd charter of Richard II, being a transcript of the previous one. See also Luffman, n 3, pp 109-14.

${ }^{551}$ Ibid, p 371. This charter is referred to in the charter of Charles I (see no 41). See also Birch, n 3, pp 162 \& xxxi. See also Anon, n $3, p 16$ and Sharpe, n 30, p 308.

${ }^{552}$ Norton, n 3, pp 371-2 refers to a 2nd charter of Henry IV. However, it was more likely an Act to repeal 7 Hen IV c 9 (allowing strangers to sell wholesale in London).

${ }_{553}$ Ibid, p 372.

${ }^{554}$ Ibid. See also CMC, n 14, p 17- 8.
} 
(31) $2^{\text {nd }}$ Charter of Edward IV of 27 August 1463 (a) confines the weighing of wool to Leadenhall market and that there be no staple within 3 miles of the same.

(32) $3^{\text {rd }}$ Charter of Edward IV of 20 June 1478 (a) the king gives the mayor etc liberty to purchase lands in mortmain to the value of 200 marks pa.

(33) $4^{\text {th }}$ Charter of Edward IV of 20 June 1478 (a) grants to the mayor and commonalty the offices of: packing, portage, garbling, gauging, wine drawing; (b) also, the office of coroner.

(34) Regulations of Henry VII of 22 August 1485 (a) confirms that, if strangers to the City buy (or sell) any wares or merchandise of any other stranger, all merchandises so brought to be forfeited etc; (b) confirms the office of guager. ${ }^{555}$

(35) $1^{\text {st }}$ Charter of Henry VIII of 16 June 1518 (a) removes sessions from St Martin Le Grand (see (24)) to the Guildhall, saving inquisitions taken in eyre in the Tower of London and for the goal delivery of Newgate. 556

(36) $2^{\text {nd }}$ Charter of Henry VIII of 13 April 1531 (a) cancels Sir William Sidney's patent of 1521 as keeper of the great beam and common balance of the City; (b) declares the mayor to be the keeper of the great beam, common balance and of weights in the City with the power to make and assign clerks, porters etc with all the fees belonging thereto.

(37) Charter of Edward VI of 23 April 1550 (a) grants to the mayor and citizens of London several messuages (parcels of land) in Southwick and Surrey excepting certain messuages; (b) grants to the mayor and citizens the manor of Southwark belonging to the late monastery of Belmondsey with all the appurtenances; also the manor and borough of Southwark late possession of the Archbishop of Canterbury with several other lands, tenements etc in as full and large a manner as the Duke of Suffolk or any abbot of Belmondsey or Archbishop of Canterbury did enjoy the same; and in as full and large a manner as the same came or ought to have come to this father Henry VIII: (c) grants waif, estray, treasure found, goods of traitors, felons, fugitives, outlaws, doodads ${ }^{557}$ disclaimed and found goods, escheats and forfeitures formerly belonging to the king and his heirs; (d) also assize of bread, wine, beer, ale and whatsoever did belong to the clerk of the market; likewise the execution and return of writs, warrants etc; (d) grants a fair at Southwark for 3 days every year with a court of piepoudre; (e) view of frankpledge, ${ }^{558}$ together with all summons, attachments, arrests, issues, profits etc which may, or ought, to belong to the king etc; (f) liberty to apprehend felons, thieves, and other malefactors within the said town, borough etc and to carry them to Newgate; (g) the mayor, commonalty and shall have the same liberties in the borough and town aforesaid as the king would have if the same were in his hands; (h) the mayor etc should hold pleas in London for matters in Southwark and the jurors in Southwark making default before the mayor and sheriffs of London should forfeit their issues and suffer such amercements as men empanelled and summoned in the said City are liable to; (i) mayor and commonalty to have cognizance of all manner of pleas, actions, plaints and suits personal arising in Southwark; (j) mayor may choose 2 coroners for Southwark and that no coroner belonging to the king has power to meddle there; $(\mathrm{k})$ mayor be escheator of Southwark and clerk of the market in Southwark; (1) mayor to have all franchises, stallage, pickage etc which the Archbishop of Canterbury, Duke of Suffolk, master of hospital of St Thomas, abbot of Belmondsey or prior of St Mary Overy enjoyed and that none of the king's officers do meddle in the town and borough of Southwark; (m) all inhabitants of Southwark to be under the magistracy of the mayor and officers of London and the mayor to have the same jurisdiction as in London; (n) mayor, recorder and certain aldermen shall be JP's in Southwark; (o) that there be markets for Southwark 4 days a week, without prejudice to the steward of the king's house; (p) saves the City harmless from all corodies, rates, fees and annuities given out or paid out of the premises, reserving a fee farm of $£ 10$.

(38) $1^{\text {st }}$ Charter of James I of 20 August $1605{ }^{559}$ (a) grants to the mayor to be his bailiff and have conservation of the Thames up to Staines bridge (westward) and Kendal (eastward) and in the Medway

\footnotetext{
555 These letters confirm letters patent of Henry VII (1485-1509) which appear to have been issued on 23 July 1485. See CMC, n 14, p 19. See also Luffman, n 3, pp 147-51.

${ }^{556}$ Norton, n 3, p 385 refers to this as the 2nd charter since he refers to a charter of 12 July 1509 in which Henry VIII confirmed the 1 st charter of Henry IV in which tronage was granted to the City (see no 29, charter of Henry IV).

${ }^{557}$ A personal chattel which had been the immediate cause of death of a living being was forfeit to the Crown, to be applied to pious uses. Abolished in 1862 .

${ }^{558}$ All men of 14 years and above were to find surety towards the king and his subjects or else they were sent to prison. Also, in Anglo-Saxon times all persons were prohibited from residing 40 days in a district without becoming enrolled in a frankpledge. See Pulling, n 3, p 380 .

${ }^{559}$ For charters of inspeximus and confirmation of Mary I and Elizabeth I, see CMC, n 14, p 21.
} 
and the Port of London (including wharfs) with the fees and profits there belonging; (b) confirms the mayor in the office of measurers of all coals, grain and other merchandise.

(39) $2^{\text {nd }}$ Charter of James I of 20 September $1608{ }^{560}$ (a) confirms previous charters and liberties; (b) ratifies the rights of search, survey and measuring which pertain to the mayor; (b) extends the liberties of the City through the parish of Trinity near Aldgate or Duke's Place, St Bartholomew (Great and Little) Blackfriars, Whitefrairs and Cold Harbour; (c) non freemen in the City are to be taxed equally with citizens in all aids; (d) mayor, recorder and certain aldermen to be justices of oyer and terminer and shall hold jurisdiction in the extended liberties with power to take security for the preservation of the peace; (f) sheriffs to assist the justices; (g) all treasure, waifs, estrays, goods and chattels of felons, fugitives, deodands, disclaimed and found goods etc in the extended liberties to belong to the City.

(40) $3^{\text {rd }}$ Charter of James I of 15 September 1614 (a) mayor be the measurer of all coals in the port of London from Yenleet to Staines Bridge.

(41) $1^{\text {st }}$ Charter of Charles I of 18 October 1638 (a) confirms charters referred to in (1)-(39), except those in the same charters excepted ${ }^{561}$ (b) repeats the several names of the corporation and makes restitution of all their liberties, except some that are therein excepted; (c) recites the charter of Henry VI of 26 October 1445 and likewise the soil etc of the streets and the Thames granted to the City and all other charters of Henry VI are made void and some doubts concerning the validity of the charter granted to the City the $20^{\text {th }}$ Henry VII (23 July 1505); (d) mayor, recorder and certain aldermen to be JP's and to hold sessions of the peace, to enquire into several offences to make and continue process and punish offenders and power to execute the laws as fully as other JP's in other counties; (e) sheriffs to assist the JP's; (f) grants forfeiture of recognizances, particularly those relating to bastard children, inmates and alehouses, with recognizances for appearances at the sessions of goal delivery, fines and issues of jurors within the City; (g) grants recognizances for the security of peace or good behaviour and recognizances for the river Thames and things thereto appertaining; likewise all fines, amerciaments and penalties adjudged by the mayor relating to the said courts as conservator of the river Thames; also all fines imposed by the Commissioners of Sewers; (h) grants to the mayor all messuages, houses etc erected on void grounds within the City and liberties; (i) grants to the mayor, Moorfields and West Smithfield with the liberty to hold fairs and markets in those fields together with all tolls profits etc belonging, reserving the streets, waste ground, common soil etc within the city and liberties to hold the same in free burbage; (j) grants the office of garbling spices to the mayor (excepting tobacco) with all fees; (k) grants the office of gauging to the mayor with all the fees; (l) grants to the mayor the keeper of the great beam or weight within the City, with all fees; (m) grants to the mayor the office of outroper (or common crier) in London and Southwark, to exercise the same by deputy; (n) freeman's widows empowered to use their husbands arts and manual occupations for so long as they continue widows; (o) prohibits markets within 7 miles of the city; (p) grants that, according to the ancient custom, the mayor should record their customs via the mouth of their recorder touching any plea, deed, cause or business relating to the City; (q) grants to the mayor etc all treasure found in the City, all waifs, strays, goods and chattels of felons, fugitives etc; (r) grants that the mayor shall nominate 2 aldermen for JP's, one to be inserted in all commissions in Surrey, the other in Middlesex; (s) obliges merchants in the City and within 10 miles thereof to take up their freedom; (t) no merchant, a freeman of London, may take any person to serve him as an apprentice for any less term than 7 years; (u) grants to the City a court of Request for the trying of all debts under 40s; (v) establishes a register of pawns and grants to the mayor the office of broker of pawns; (w) citizens, for the better finding of their dwellings, might hang out signs; (x) grants to the mayor the keeping of the hospital Bethlehem, the mayor to be governor, and declares that no lease should be for more than 21 years; (y) grants mayor the liberty to purchase 5 acres of land in St Giles-in-the-Fields.

(42) $2^{\text {nd }}$ Charter of Charles I of 5 September 1640 (a) confirms the offices of package, portage, scavage and baillage and grants them to the mayor, with all fees and profits; (b) all aliens and denizens shall make and deliver to the mayor etc bills of entry for goods; (c) punishes fraudulent landings; (d) empowers the mayor to administer the oath in the case of concealed goods.

(43) $1^{\text {st }}$ Charter of Charles II of 24 June 1663 (a) confirms previous charters. ${ }^{562}$

\footnotetext{
${ }^{560} \mathrm{CMC}, \mathrm{n} 14, \mathrm{p} 21$ says 24 September 1608.

${ }^{561}$ Also, except those in the these fns.

${ }^{562}$ A judgment of quo warranto in 1688 against the City seized the liberty, privilege and franchise of the mayor and commonalty and citizens of the London into hands of the king. An Act of 1690 ( 2 W \& M c 8) vacated it and confirmed all the privileges of the City. The Act, s 4 also vacated any charters made by Charles II (1660-85) or James II (1685-9) relating to the said liberties and franchises. See Birch, n 3 ,
} 
(44) Charter of William and Mary of 28 July 1692. (a) constitutes JP's the 6 senior aldermen who had not passed the chair (in addition to the 3 senior aldermen who had not passed the chair created JP's by the $1^{\text {st }}$ charter of Charles I (see no 41)) to be JP's provided they had served the office of sheriff.5 ${ }^{53}$

(45) Charter of George II of 25 August 1741. (a) constitutes JP's all aldermen of the City. ${ }^{564}$

\section{References}

Allen, J. (1849). Inquiry into the Rise and Growth of The Royal Prerogative in England. London: Longmans.

Allen, W. F. (1858). The Corporation of London (reprint 2006). Dodo Press.

Anon. (1765). The Laws and Customs, Rights, Liberties, and Privileges of the City of London (Printed for R. Withy \& W. Griffin).

Anson, W. R. (1935). The Law and Custom of the Constitution (4th ed.). Oxford: Clarendon Press.

Arnold, R. (1811). Chronicle (reprint of 1502 edition).

Attenborough, H. L. (1922). The Laws of the Earliest English Kings. Cambridge University Press.

Bacon, M. (1798). New Abridgment of the Law (5th ed.). London: A Strahan.

Baker, J. H. (2002). An Introduction to Legal History. Butterworths.

Ballard, A. (1913). British Borough Charters 1042-1216. Cambridge University Press.

Ballard, A., \& Tait, J. (1923). British Borough Charters 1216-1307. Cambridge University Press.

Barendt, E. (1998). An Introduction to Constitutional Law. Oxford University Press.

Bateson, M. (1904-5). Borough Customs. Selden Society, vols 18 \& 20.

Birch, W. G. (1884). The Historical Charters and Constitutional Documents of the City of London. London: Whiting.

Bird, R. (1949). The Turbulent London of Richard II. Longmans.

Blackstone, W. (1765-9). Commentaries on the Laws of England (1st ed.). Oxford: Clarendon Press (University of Chicago Press, reprint in 1979).

Blount, T. (1784). Fragmenta Antiquitatis (2nd ed.). Butterworths.

Bohun, W. (1723). Privilegia Londini or the Rights, Liberties and Privileges,Laws and Customs of the City of London. ( $3^{\text {rd }}$ ed.). London: D Browne etc.

Bracton (translated by S. E. Thorne). (1968). On the Law and Customs of England (c. 1240). Harvard University Press.

Brady, R. (1711). An Historical Treatise of Cities and Bughs or Boroughs. London.

Bradley, A. W., \& Ewing, K. D. (2006). Constitutional and Administrative Law (14th ed.). Longman.

Brandon, W. (1876). The Lord Mayor's Court of the City of London. Butterworths.

Brandon, W. (1861). A Treatise upon the Customary Law of Foreign Attachment, and the practice of the Mayor's Court of the City of London therein. Butterworths.

Britton (c 1290) (1901). ed FM Nichols, pub Washington, John Byrne.

Brooke, C., Keir, G., \& Reynolds, S. (1973). Henry I's Charter for the City of London. Journal of the Society of Archivists.

Brooke, R. (1586). La Graunde Abridgment. London: Tottell.

Brougham, H. (1861). The British Constitution. London: Griffin, Bohn \& Co.

Calthorp, H. (1670). Reports of Special Cases touching several Customs and Liberties of the City of London. London: Abel Roper (it includes the Ancient Customs and Usages of the City of London).

Cam, H. M. (1957). Selected Historical Essays of FW Maitland. Cambridge University Press.

Carter, A. T. (1944). A History of the English Courts (7th ed.). Butterworth \& Co.

pp xxxix-xliii \& pp 266-74. Also, Blackstone, n 2, vol 3, pp 262-4.

${ }^{563}$ See Norton, n 3, p 407. Also, CMC, n 14, p 25.

${ }^{564} \mathrm{CMC}, \mathrm{n} 14, \mathrm{p} 25$. 
Chew, H. M. (1943). The Office of Escheator in the City of London during the Middle Ages. English Historical Review, 55.

Chitty (Junior), J. (1820). A Treatise of the Law of the Prerogatives of the Crown. London: Butterworths.

2nd Report of the Commissioners on the Municipal Corporations of England and Wales (1969). Irish University Press Series, 6. (CMC).

Coke, E. (1824). Institutes of the Laws of England. London: W Clarke \& Sons.

Comyns, J. (1822). Digest of the Laws of England. London: A Hammond.

Corporation of London. (1953). The Corporation of London. Cumberlege: Oxford University Press. ('COL')

Daly, D. B. (1861). Practice in the Lord Mayor's Court. London. Wildy \& Sons, Lincoln's Inn.

D'Anvers, K. (1725-37). General Abridgment of the Common Law. (printed for E \& R Nutt and R Gosling).

Department of Transport. (2010). Statutory Tolled Undertakings and Road User Charging Schemes in the UK (DOT pub). ('DOT')

De Smith, S. A., \& Brazier, R. (1998). Constitutional and Administrative Law (8th ed.). Penguin.

Dicey, A. V. (1948). Introduction to the Study of the Law of the Constitution (9th ed.). Macmillan.

Dowell, S. (1888). History of Taxes and Taxation in England. Longmans, Green.

Downer, L. J. (Ed.) (1972). Leges Henrici Primi. Oxford: Clarendon Press.

Eboranos. (1737). The History of the Ancient Office of Clerk of the Market. London.

Emerson, T. (1794). A Concise Treatise of the Courts of Law of the City of London (printed by J. Nichols).

Fitzherbert, A. (1577). La Graunde Abridgment (3rd ed.). London: Tottell.

Fitzherbert, A. (1793). New Natura Brevium (9th ed.). Dublin.

Fitzstephen. (1173). Description of London (contained in the text by Stow).

Fleta (c. 1290), Selden Society Reports, 72.

Forbes, U. A., \& Coulson, H. J. W. (1902). The Law Relating to Waters, Sea, Tidal and Inland (2nd ed.). Sweet \& Maxwell.

Glasspool, A. J. (1924). The Corporation of the City of London: Its Ceremonies and Importance. London: Effingham Wilson.

Glyn, L. E., \& Jackson, F. S. (1910). The Jurisdiction and Practice of the Mayor's Court Practice (3rd ed.).

Gomme, G. L. (1907). The Governance of London. London: Unwin.

Green, J. R. (1893). A Short History of the English People. London: Macmillan.

Gross, G. (1967). The Gild Merchant. Oxford: Clarendon Press (1967 reprint).

Gunning, F. (1833). A Practical Treatise on the Law of Tolls. London: Saunders \& Benning.

Haines, R. M. (2003). King Edward II. McGill University Press.

Hallam, H. (1897). Constitutional History of England. London: J. Murray.

Hallett, A. (2009). Markets and Marketplaces of Britain, ch 6.

Halsbury. Laws of England (4th ed.).

Halsbury. Statutes of the Laws of England (4th ed.).

Hargrave, F. (Ed.), \& Hale, M. (1787). A Treatise relative to the Maritime Law of England in Three Parts. London. (reprinted by Gale EEBO Print).

Harrison, O. B. C. (1860). The Law and Practice of the Sheriff's Court of the City of London. H Sweet.

Holdsworth, W. (2009). A History of English Law.

Hollister, W. (1980). London's First Charter of Liberties: Is it Genuine? Journal of Medieval History.

Holt, J. C. (1969). Magna Carta. Cambridge University Press.

Hughes, W. (1660-3). Grand Abridgment of the Law. London: Henry Twyford etc al.

Hume, D. (1884). The History of England. London: Frederick Warne \& Co. 
Inwood, S. (1998). A History of London. New York: Carroll \& Graf.

Jacob, G. (1732). City Liberties. London. (printed by E. \& R. Nutt \& R. Gosling).

Jeake S. (1728). Charters of the Cinque Ports, Two Ancient Towns and their Members. London.

Jennings, I. (1959). The Law and the Constitution. (5th ed.). University of London Press.

Jolliffe, J. E. A. (1948). Constitutional History of Medieval England (2nd ed.).

Keene, D. (2008). Text Visualisation and Politics:London 1150-1250. Transactions of the Royal Historical Society, 6th series.

Keir, D. L., \& Lawson, F. H. (1979). Cases in Constitutional Law (6th ed.). Oxford: Clarendon Press.

Kingdon, J. A. (1901). Richard Grafton, Citizen and Grocer (privately printed, London, Rixon \& Arnold).

Le Sueur, A. \& Sunkin, M. (1997). Public Law. Longman.

Lex Londinensis or the City Law. (1680). London: S Roycroft. ('LL')

Liebermann, F. (1916). Die Gesetze der Angelsachsen. Halle.

Lilley, J. (1765). (2nd ed.). Practical Register.

Little, A. G, \& Powicke, F. M. (Eds). (1925). Essays in Medieval History presented to TF Tout. Manchester University Press.

Locke, J. (1853). Law and Practice of Foreign Attachment in the Lord Mayor's Court. London: S Sweet.

Luffman, J. (1793). The Charters of London. London (printed for J. Luffman).

McBain, G. S. (2005). Time to Abolish the Common Carrier. Journal of Business Law.

McBain, G. S. (2006). Abolishing the Strict Liability of Hotelkeepers. Journal of Business Law.

McBain, G. S. (2009). Abolishing some Obsolete Common Law Crimes. King's Law Journal.

McBain, G. S. (2010). Modernising the Monarchy - In Legal Terms. King's Law Journal, 21(3).

McBain, G. S. (2011a). Abolishing some more Obsolete Crown Prerogatives. Liverpool Law Review (online 27 April 2011).

McBain, G. S. (2011b). Modernising the Monarchy - In Legal Terms. King's Law Journal, 22(1).

McBain, G. S. (2011c). Abolishing Obsolete Crown Prerogatives relating the Military. Nottingham Law Journal.

McBain, G. S. (2012a). Abolishing various Obsolete Courts. Coventry Law Journal, 17(1).

McBain, G. S. (2012b). Abolishing Obsolete Crown Prerogatives relating to: Martial Law, Conscription and Billeting. International Law Research, 1(1).

McKechnie, W. S. (1914). Magna Carta (2nd ed). Glasgow: J Maclehose.

Madge, S. J. (1938). The Domesday of Crown Lands. London: Routledge.

Madox, T. (1989). Firma Burgi. Cambridge University Press (reprint of 1726 work).

Maitland, W. R. (1756). The History of London. London: T Osborne, J Shipton \& J Hodges.

Maitland, F. W. (1963). The Constitutional History of England. Cambridge University Press.

Manwood, J. (1741). Treatise of the Forest Laws (5th ed.). London: H Lintot.

Marshall, G. (1971). Constitutional Theory. Clarendon Press: Oxford.

Ministry of Agriculture and Fisheries. Report on Markets and Fairs in England and Wales (HMSO, 7 parts in 5 vols, 1927-30) ('MAF').

The Mirror of Justices. (c. 1290). Selden Society, 7.

Moore, S. A. (1888). A History of the Foreshore and the Law relating thereto. London: Stevens \& Haynes.

Nelson, W. (1725-6). Abridgment of the Common Law. London: E \& R Gosling.

Noorthouck, J. (1773). New History of London. London: R Baldwin.

Norton, G. (1869). Commentaries on the History, Constitution \& Chartered Franchises of the City of London. London: Longmans. 
Norton, G. (1821). An Exposition of the Privileges of the City of London in regard to the Claims of Non-freemen to deal by Wholesale within its Jurisdiction. London: R Jennings.

O’Brien, B. R. (1999). God's Peace and King's Peace: The Laws of Edward the Confessor. University of Pennsylvania Press.

O'Keefe, J. A. (1978). The Laws of Weights and Measures (2nd ed.).

Owen, D. (1982). The Government of Victorian London 1855-1889. Belknap Press.

Oxford Dictionary of National Biography (ODNB).

Oxford English Dictionary (OED).

Page, W. (Ed). (1911). A History of the County of Middlesex. Victoria County History (British History online).

Page, W. (1929). London. Its Origin and Early Development. London: Constable.

Pease, J. G., \& Chitty, H. (1899). Treatise on the Law of Markets and Fairs. London: Knight \& Co.

Petit-Dutaillis, C. H., \& Lefebre, G. (1930). Studies and Notes Supplementary to Stubbs Constitutional History. Manchester University Press.

Phillips, S. (2010). Edward II. Yale University Press

Phillips, O. H., \& Jackson, P. (2001). Constitutional and Administrative Law (8th ed.). Sweet \& Maxwell.

Pollock, F., \& Maitland, F. W. (1984). The History of English Law (2nd ed.). Cambridge University Press.

Preest, D. (2005). The Chronica Maiora of Thomas Walsingham 1376-1422. Boydell Press.

Pugh, R. B. (1968). Imprisonment in Medieval England. Cambridge University Press.

Pulling, A. (1854). The Laws, Customs, Usages and Regulations of the City and Port of London (2nd ed.). WH Bond: London.

Reports of the Commissioners on the Amalgamation of the City and County of London. (1894). (HMSO, C 7493), vols 17 \& 18.('RC').

Report of the Commissioners into the Existing State of the Corporation of the City of London (1854). Eyre \& Spottiswoode. ('RC-54')

Riley, H. T. (1859-62). Munimenta Gildhallae Londoniensis. Rolls Series. (It includes the Liber Albus, 1419).

Riley, H. T. (1868). Memorials of London and London Life. London: Longmans.

Riley, H. T. (1863). Chronicles of the Mayors and Sheriffs of London 1188-1274. London. (It contains a translation of the Liber de Antiquis Legibus (c. 1274)).

Robertson, A. J. (1925). The Laws of the Kings of England from Edmund to Henry I. Cambridge University Press.

Robertson, C. G. (1935). Select Statutes Cases and Documents (7th ed.). London: Methuen \& Co.

Rolle, H. (1668). Abridgment des plusieurs Cases et Resolutions del Common Ley. London: A Crooke et al.

Round, J. H. (1899). Commune of London. Westminster: Archibald Constable \& Co.

Round, J. H. (1892). Geofffrey de Mandeville. London: Longmans.

Seyer, S. (1812). The Charters and Letters Patent granted by the Kings and Queens of England to the Town and City of Bristol. Bristol: JM Gutch.

Sharpe, R. G. (Ed). (1899). Calendar of Letterbooks of the City of London. London: JE Francis (11 vols) ('Letterbooks').

Sharpe, R. R. (1894). London and the Kingdom. London: Longmans.

Sheppard, W. (1759). Grand Abridgment of the Common and Statute Law of England. London: George Sawbridge.

Statham, N. (1490). Abridgment of the Law. London: Pynson.

Stenton, F. (1989). Anglo-Saxon England. Oxford University Press (reprint of 1943 edition).

Stow, J. (1965). The Survey of London. London: Dent (reprint 1965).

Stubbs, W. (1966). Select Charters of English Constitutional History (9th ed.). Oxford: Clarendon Press.

Stubbs, W. (1883). The Constitutional History of England (4th ed.). Oxford: Clarendon Press. 
Sunkin, M., \& Payne. (1999). The Nature of the Crown. Oxford University Press.

Sutherland, D. W. (1982). The Eyre of Northamptonshire 1329-1330. Selden Society Reports, 98.

Sweet \& Maxwell. (1955). A Legal Bibliography of the British Commonwealth of Nations (2 vols).

Taswell-Langmead, P. (1960). English Constitutional History (11th ed.). Sweet \& Maxwell.

Thomas, A. H. (1924-61). Calendar of Select Pleas and Memoranda of the City of London (7 vols). Cambridge University Press.

Thomas, A. H. (1924). Calendar of Early Mayor's Court Rolls (1298-1307). Cambridge University Press.

Thomson, M. A. (1938). Constitutional History of England. London: Methuen.

Thorpe, B. (Ed). (1840). Ancient Laws and Institutes of England. Commissioners of the Public Records of the Kingdom.

Viner, E. (1741-57). A General Abridgment of the Law and Equity (1st ed.). London: GCJ \& J Robinson.

Vinogradoff, P. (1892). Villainage in England. Oxford: Clarendon Press.

Walker, D. M. (1980). The Oxford Companion to Law. Oxford: Clarendon.

Welch, C. (1909). History of the Worshipful Company of Paviors (published by the same).

Weinbaum, M. (1943). British Borough Charters 1307-1660. Cambridge University Press.

Whitelock, D. (Ed). (1965). The Anglo-Saxon Chronicle (2nd ed.). London: Eyre \& Spottiswoode.

Wilkinson, B. (1958). Constitutional History of Medieval England. Longmans.

Woolrych, H. W. (1829). A Treatise on the Law of Ways, including Highways, Turnpike Roads and Tolls, Private Rights of Way, Bridges and Ferries. London: Saunders \& Benning. 